\title{
RECONSTRUCTION OF STREAMFLOW RECORDS IN THE PASSAIC AND HACKENSACK RIVER BASINS, NEW JERSEY AND NEW YORK, WATER YEARS 1993-96
}

U.S. GEOLOGICAL SURVEY

Water-Resources Investigations Report 01-4078 



\section{RECONSTRUCTION OF STREAMFLOW RECORDS IN THE PASSAIC AND HACKENSACK RIVER BASINS, NEW JERSEY AND NEW YORK, WATER YEARS 1993-96}

By Donald A. Storck and John P. Nawyn

U.S. GEOLOGICAL SURVEY

Water-Resources Investigations Report 01-4078

Prepared in cooperation with the NEW JERSEY DEPARTMENT OF ENVIRONMENTAL PROTECTION

West Trenton, New Jersey

2001

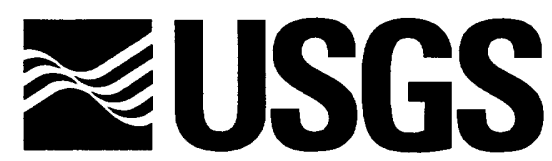




\section{U.S. DEPARTMENT OF THE INTERIOR \\ Gale A. Norton, Secretary}

\section{U.S. GEOLOGICAL SURVEY}

Charles G. Groat, Director

District Chief

U.S. Geological Survey

Mountain View Office Park

810 Bear Tavern Road, Suite 206

West Trenton, NJ 08628
U.S. Geological Survey

Branch of Information Services

Box 25286

Denver, CO 80225-0286 


\section{CONTENTS}

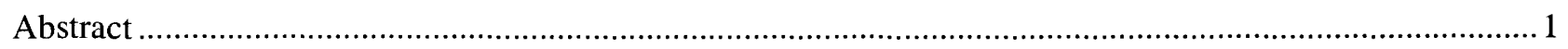

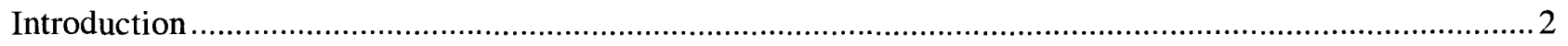

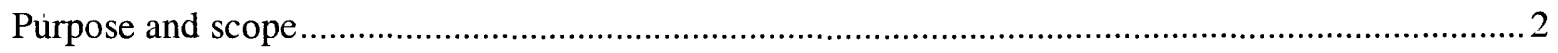

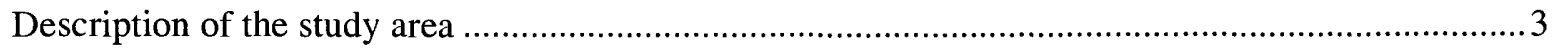

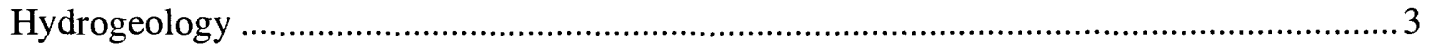

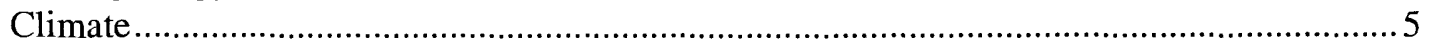

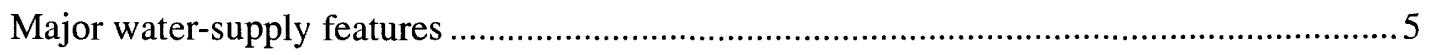

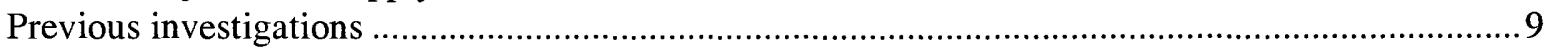

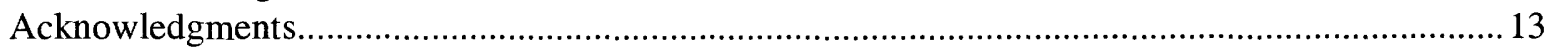

Sources, estimation, and description of data used to reconstruct streamflow records ................................ 13

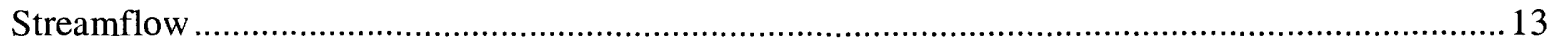

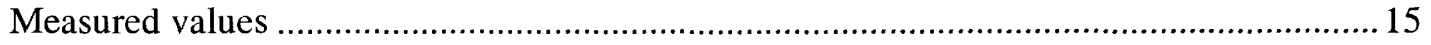

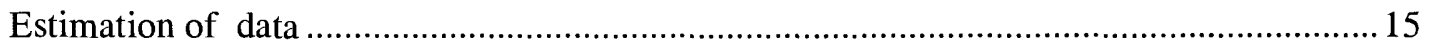

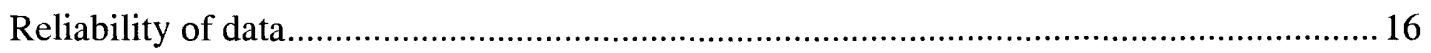

Withdrawals of ground water and surface water................................................................. 18

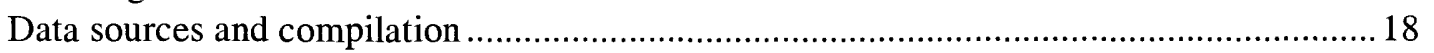

Methods used to estimate water withdrawals ........................................................... 19

Estimation of response of streamflow to ground-water withdrawals ................................20

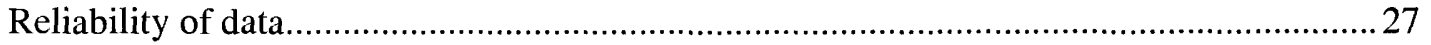

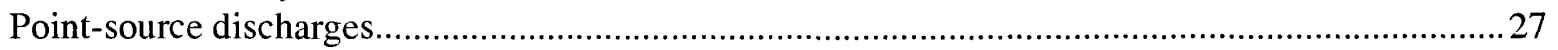

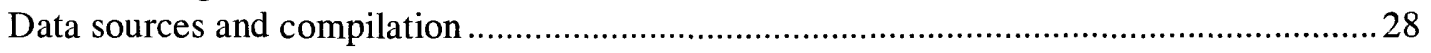

Methods used to estimate wastewater discharges ........................................................ 28

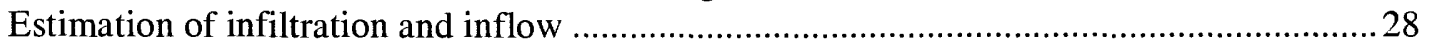

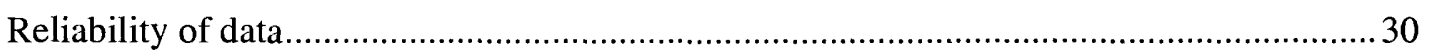

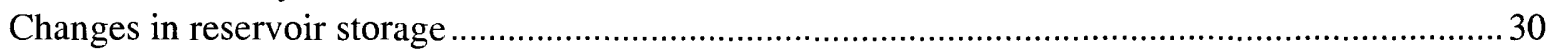

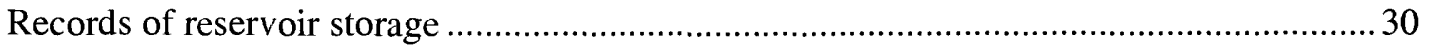

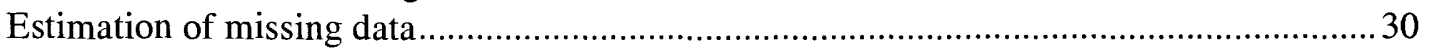

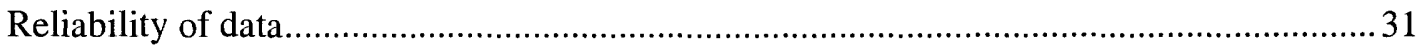

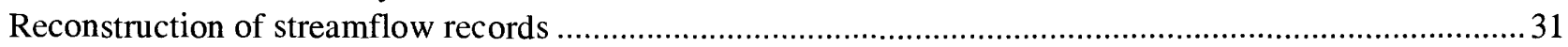

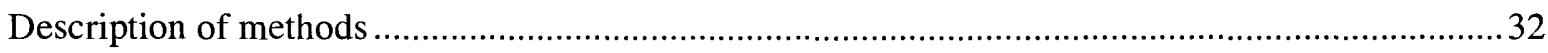

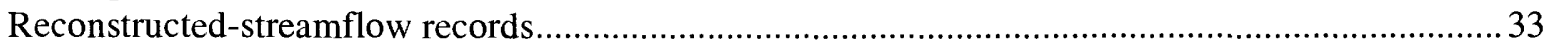

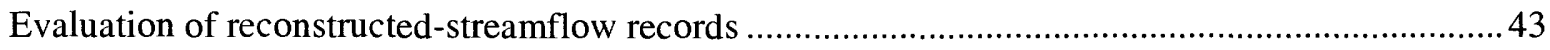

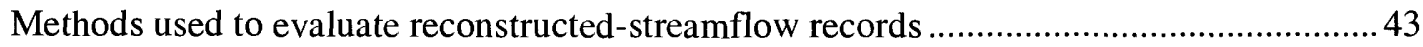

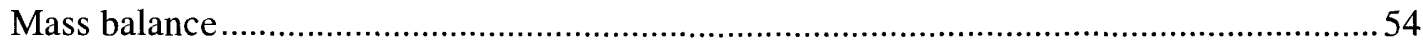

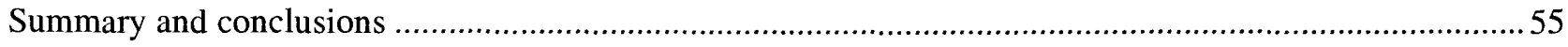

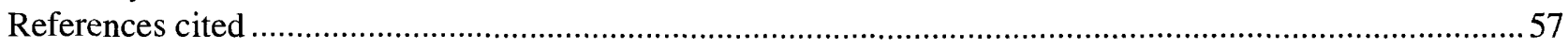

Appendix 1. Hydrographs showing monthly mean observed and reconstructed streamflow from

October 1992 through September 1996 by subwatershed for 34 streamflow-gaging

stations in the Passaic and Hackensack River Basins, New Jersey and New York ...............60

2. Hydrographs showing daily mean observed and reconstructed streamflow from

May 1, 1995, through October 31, 1995, by subwatershed for 34 streamflow-gaging stations in the Passaic and Hackensack River Basins, New Jersey and New York. 


\section{ILLUSTRATIONS}

Plate 1. Locations of streamflow-gaging stations, surface-water-withdrawal and point-source-disch $c$ rge sites, and reservoirs in the Passaic and Hackensack River Basins, New Jersey and New York in pocket

2. Locations of streamflow-gaging stations, wells, and reservoirs in the Passaic and Hackensack River Basins, New Jersey and New York in pocket

Figure 1. Map showing locations of the Passaic and Hackensack River Basins, major reservoirs, and 34 streamflow-gaging stations in New Jersey and New York

2. Graph showing total monthly precipitation in the Northern climatological division of New Jersey, October 1992 - September 1996, and departure from average (1961-90) monthly precipitation

3. Graph showing average monthly temperature in the Northern climatological division of New Jersey, October 1992 - September 1996, and departure from average (1961-90) monthly temperature

4-8. Schematic diagrams showing:

4. Relation of high-volume surface-water-withdrawal sites in subwatersheds to streamflow-gaging stations and water-supply reservoirs, Passaic and Hackensack River Basins, New Jersey and New York

5. Relation of high-volume point-source-discharge sites in subwatersheds to streamflow-gaging stations and water-supply reservoirs, Passaic and Hackensack River Basins, New Jersey and New York

6. Subwatersheds from which average ground-water withdrawals exceed 1 cubic foot per second, Passaic and Hackensack River Basins, New Jerrey and NewYork

7. The hydrologic cycle

8. Sources of water to wells: (a) area contributing recharge to a shallow well; (b) area contributing recharge to a shallow well where pumping induces infiltration of surface water; (c) areas contributing recharge to a deep well and potential upland source areas of runoff .

9. Graphs showing difference between reconstructed streamflow with no delay and reconstructed streamflow with ground-water withdrawals delayed 3 months for streamflow-gaging stations in the Ramapo River Basin, New Jersey and New Ycrk .... 24

10. Graphs showing difference between reconstructed streamflow with no delay and reconstructed streamflow with ground-water withdrawals delayed 6 months for streamflow-gaging stations in the Ramapo River Basin, New Jersey and New Ycrk .... 25

11-13. Hydrographs showing:

11. Monthly reconstructed streamflow for station 01388000 , Ramapo River at Pompton Lakes, N.J., with ground-water withdrawals delayed by 0,3 , and 6 months, and with no ground-water withdrawals.....

12. Components of reconstructed streamflow and difference between observed and reconstructed streamflow at Ramapo River at Pompton Lakes, New Jers :y..... 34

13. Observed and reconstructed streamflow with components used to calculate reconstructed streamflow at Pompton River at Pompton Plains, New Jer:ey ... 35

14-17. Schematic diagrams showing:

14. Relation of high-volume point-source-discharge sites and surface-water- anc ground-water-withdrawal sites to streamflow-gaging stations and reservoirs in the Pequannock, Wanaque, and Ramapo River Basins, New Jersey an 7 New York 


\section{ILLUSTRATIONS}

Figures 14-17. Schematic diagrams showing:--Continued

15. Relation of high-volume point-source-discharge sites and surface-water- and ground-water-withdrawal sites to streamflow-gaging stations and reservoir: in the Hackensack River Basin, New Jersey and New York

16. Relation of high-volume point-source-discharge sites and surface-water- and ground-water-withdrawal sites to streamflow-gaging stations in the Pompton, Lower Passaic, and Saddle River Basins, New Jersey

17. Relation of high-volume point-source-discharge sites and surface-water- and ground-water-withdrawal sites to streamflow-gaging stations and reservoirs in the Rockaway, Whippany, and Upper Passaic River Basins, New Jersey ..... 42

18-21. Hydrographs showing:

18. Average observed and reconstructed streamflow for August-September and March-April 1993-96 for streamflow-gaging stations on the Passaic River, New Jersey....

19. Average observed and reconstructed streamflow normalized by drainage area for August-September and March-April 1993-96 for streamflow-gaging stations on the Passaic River, New Jersey.

20. Average observed and reconstructed streamflow for August-September and March-April 1993-96 for streamflow-gaging stations on the Ramapo, Pompton, and Lower Passaic Rivers, New Jersey and New York

21. Average observed and reconstructed streamflow normalized by drainage area for August-September and March-April 1993-96 for streamflow-gaging stations on the Ramapo, Pompton, and Lower Passaic Rivers, New Jersey and New York

\section{TABLES}

Table 1. Streamflow-gaging stations used in the study and associated information

2. Equations used to estimate observed streamflow at stations with missing or incomplete records, Passaic and Hackensack River Basins, New Jersey and New York

3. Reservoirs for which change-in-storage values were calculated and associated information

4. Equations used to calculate reconstructed streamflow at gaging stations in the study area.............36

5. Summary of surface-water-withdrawal, ground-water-withdrawal, and point-source-discharge sites and reservoirs used to reconstruct streamflow records, mean withdrawals and discharges, and additional statistics, Passaic and Hackensack River Basins, New Jersey and New York

6. Average observed and reconstructed streamflow for August through September and March through April during 1993-96 for streamflow-gaging stations on the Passaic River, New Jersey

7. Average observed and reconstructed streamflow for August through September and March through April during 1993-96 for streamflow-gaging stations on the Ramapo, Pompton, and Lower Passaic Rivers, New Jersey and New York

An electronic data diskette containing data used to reconstruct monthly and daily streamflow records and other information is available upon request from the U.S. Geological Survey, New Jersey District, office in West Trenton, N.J. (609-771-3900). 


\section{CONVERSION FACTORS, VERTICAL DATUM, AND ABBREVIATIONS}

Multiply

inch (in.)

foot ( $\mathrm{ft})$

mile (mi)

square foot $\left(\mathrm{ft}^{2}\right)$

square mile $\left(\mathrm{mi}^{2}\right)$

square mile $\left(\mathrm{mi}^{2}\right)$

gallon (gal)

gallon (gal)

million gallons (Mgal)

cubic foot per second $\left(\mathrm{ft}^{3} / \mathrm{s}\right)$

gallon per minute ( $\mathrm{gal} / \mathrm{min}$ )

gallon per day (gal/d)

million gallons per day (Mgal/d)

million gallons per day (Mgal/d)

Degree Fahrenheit $\left({ }^{\circ} \mathrm{F}\right)$

foot per day (ft/d)

square foot per day $\left(\mathrm{ft}^{2} / \mathrm{d}\right)$
By

\section{Length}

25.4

0.3048

1.609

Area

0.09294

259.0

2.590

Volume

3.785

0.003785

3,785

Flow

0.02832

0.06308

0.003785

0.04381

1.547214

Temperature

${ }^{\circ} \mathrm{C}=5 / 9 \times\left({ }^{\circ} \mathrm{F}-32\right)$

Hydraulic conductivity

$$
0.3048
$$

Transmissivity

0.09290
To obtain

millimeter

meter

kilometer

square meter

hectare

square kilometer

liter

cubic meter

cubic meters

cubic meter per second

liter per second

cubic meter per day

cubic meters per second

cubic feet per second $\left(\mathrm{ft}^{3} / \mathrm{s}\right)$

Sea level: In this report "sea level" refers to the National Geodetic Vertical Datum of 1929-- a geodetic datum derived from a general adjustment of the first-order level nets of the United States and Canada, formerly called Sea Level Datum of 1929.

\section{Abbreviations used in the report}
ADAPS Automated Data Processing System
BSDW Bureau of Safe Drinking Water
BWA Bureau of Water Allocations
NJDEP New Jersey Department of Environmental Protection
NWIS National Water Information System
USEPA U.S. Environmental Protection Agency
USGS U.S. Geological Survey 


\title{
RECONSTRUCTION OF STREAMFLOW RECORDS IN THE PASSAIC AND HACKENSACK RIVER BASINS, NEW JERSEY AND NEW YORK, WATER YEARS 1993-96
}

\author{
By Donald A. Storck and John P. Nawyn
}

\section{ABSTRACT}

To effectively manage the water resources of the Passaic and Hackensack River Basins during periods of drought, information about the historical values of natural streamflow and the effects of human activities on streamflow is needed. This report describes the results of an investigation conducted by the U.S. Geological Survey, in cooperation with the New Jersey Department of Environmental Protection, to (1) reconstruct monthly streamflow records for 34 stations in the Passaic and Hackensack River Basins in New Jersey and New York for water years 1993-96, and (2) reconstruct daily streamflow records for these 34 stations for the drought period from May 1, 1995, through October 31, 1995. Reconstructedstreamflow records were calculated from observedstreamflow records and account for surface- and ground-water withdrawals, discharges to surfacewater bodies, changes in storage in reservoirs, water transfers, and other factors related to human activities in the drainage basins studied. Reconstructed-streamflow records can be used by waterresource managers and planners as input to watersupply management models. Results of model simulations can be used to determine whether drought warnings and emergencies are warranted and to evaluate alternative water-supply options during periods of severe drought.

Sources of monthly and daily hydrologic data used to reconstruct streamflow records and methods used to estimate missing values are described. Data were collected from government agencies as well as directly from public and private water suppliers, wastewater-treatment facilities, and other sources, and include information from 87 surface-water-withdrawal sites; about 840 wells; 265 point-source discharge facilities and 368 facility outfall pipes; and 15 reservoirs. Methods used to reconstruct streamflow records also are described.

Average reconstructed-streamflow values during the 4-year study period at the three most downstream stations in the study area were $199 \mathrm{ft}^{3} / \mathrm{s}$ (cubic feet per second) at Hackensack River at New Milford, N.J.; $105 \mathrm{ft}^{3} / \mathrm{s}$ at Saddle. River at Lodi, N.J.; and 1,550 $\mathrm{ft}^{3} / \mathrm{s}$ at Passaic Fiver at Route 46 at Elmwood Park, N.J. The differences between average reconstructed and average observed streamflow at these stations were 149, 5, and $483 \mathrm{ft}^{3} / \mathrm{s}$, respectively. The largest withdrawals of surface water account for most of this difference. At the Wanaque River at Wanaque, N.J., streamflow-gaging station, surface-water withdrawals from the subwatershed averaged 129 $\mathrm{Mgal} / \mathrm{d}$ (million gallons per day) $\left(200 \mathrm{ft}^{3} / \mathrm{s}\right)$. At the Hackensack River at New Milford, N.J., streamflow-gaging station, surface-water withdrawals from the subwatershed averaged $101 \mathrm{Mgal} / \mathrm{d}$ (156 $\left.\mathrm{ft}^{3} / \mathrm{s}\right)$. Reconstructed streamflow was less than observed streamflow in only a few instances, all of which were in subwatersheds where point-source discharges from municipal treatment facilities that receive water from sources outside the subwatershed are high and ground- and surface-water vithdrawals within the subwatershed are minimal. Differences between average reconstructedstreamflow values and average natural-streamflow values estimated by using a simplified water-balance equation were less than 10 percent. 


\section{INTRODUCTION}

In the first comprehensive report on water supply in New Jersey, Vermeule (1894) described the Passaic River as "our most valuable stream from every point of view. By a fortunate coincidence, its headwaters afford our best gathering grounds for public water supply, and at the same time are the most accessible to the points of greatest demand." The drought conditions in northern New Jersey during 1980-95 and the imposition of drought warnings and water-use restrictions have shown the vulnerability of the water resources and the problems of water management. Below-average annual precipitation was reported in 1980-82, 1985, 1988, 1991-93, and 1995 (National Climatic Data Center, 1993-97). To effectively manage the water resources of the Passaic and Hackensack River Basins during periods of drought, information about the historical values of natural streamflow and the effects of human activities on streamflow is needed.

Observed streamflow, the quantity of water that passes a given point in a stream channel within a given time period, is the result of the interaction between natural conditions and human activities. Natural streamflow is the quantity of water that would have flowed past the specified point without the influence of human activities. Reconstructed streamflow is an estimate of what streamflow would have been without major influences due to human activities. Reconstructed streamflow is the quantity of water that is determined by means of a mass-balance calculation, based on observed streamflow, that takes into consideration known surface- and ground-water withdrawals; discharges to surface-water bodies; changes in storage in water-supply reservoirs; transfers of water into, out of, or within river basins; and other factors, and is not equivalent to natural streamflow. The reconstruction method does not attempt to include all factors that may affect streamflow--for example, changes in land use, some gains and losses associated with the operation of reservoirs, and the effects of residential wells and septic systems. Many of these factors are not easily quantified, and many other factors may be unknown.
Reconstructed-streamflow records are needed for use by water-resource managars and planners as input to water-supply management models. Results of model simulations can be used to determine whether drought warnings and emergencies are warranted and to evaluate alternative water-supply options during periods of severe drought. In order to provide the data that are needed for effective water-supply management in northern New Jersey, the U.S. Geological Survey (USGS), in cooperation with the New Jersey Department of Environmental Protection (NJDEP), conducted an investigation to (1) reconst uct monthly streamflow records for 34 USGS streamflow-gaging stations for water years 1993-96, and (2) reconstruct daily streamflow records for these 34 stations for the drought period from May 1, 1995, through October 31, 1995.

\section{Purpose and Scope}

This report describes the sources of observed monthly and daily streamflow and other rydrologic data used to reconstruct streamflow records at 34 streamflow-gaging stations in the Passaic and Hackensack River Basins in New Jersey and New York, and the methods used to estimate missing values. Monthly and daily data from 87 surfacewater-withdrawal sites; about 840 wells; 265 pointsource discharge facilities and 368 facility outfall pipes; and 15 reservoirs were included in the calculation of reconstructed streamflow.

The report also describes the method used to reconstruct streamflow records at each streamflowgaging station. Monthly reconstructed-st'eamflow records for each gaging station for water years 1993 through 1996 and daily reconstruct :d-streamflow records for the drought period from May 1 through October 31, 1995, are documented. Also included are hydrographs showing observed- and reconstructed-streamflow values for eacl watershed. A compact disk, available on request from the USGS office in West Trenton, N.J., contains the data used to reconstruct streamflow records, hydrographs for all 34 gaging stations, and maps showing the locations of the sites for which data were included in the calculation. 


\section{Description of the Study Area}

The Passaic and Hackensack River Basins lie in the northeastern part of New Jersey and the southeastern part of New York State, in the Piedmont and New England (Highlands) Physiographic Provinces (fig. 1). The Passaic and Hackensack River Basins $\left(1,120 \mathrm{mi}^{2}\right)$ include all or part of Bergen, Essex, Hudson, Morris, Passaic, Somerset, Sussex, and Union Counties in New Jersey (920 $\mathrm{mi}^{2}$ ) and part of Orange and Rockland Counties in New York State $\left(200 \mathrm{mi}^{2}\right)$. The study area includes all of the surface drainage area of the Passaic and Hackensack Rivers upstream from the most downstream streamflow-gaging stations on the Passaic, Saddle, and Hackensack Rivers. The study area does not extend to Newark Bay, and is unaffected by tides. Seaber and others (1987) designated the Passaic and Hackensack River Basins as one of 13 major hydrologic units called hydrologic cataloging units (HUC's) that lie either partly or entirely within the borders of New Jersey. A HUC is a geographic area that represents a surface-water drainage basin, such as the Passaic River Basin, or a distinct hydrologic feature, such as the Delaware Bay. The 8-digit HUC code and name associated with each cataloging unit are part of a National system for locating, storing, retrieving, and exchanging hydrologic data. The Hackensack-Passaic HUC code is 02030103 (Seaber and others, 1987). For this study, the Hackensack-Passaic HUC was divided into 34 small hydrologic units called subwatersheds. A subwatershed is defined as the geographic area that drains to a given stream reach between selected streamflow-gaging stations.

The Hackensack-Passaic HUC is an area of contrasting land use. New York City borders the southeastern part of the study area. The counties adjacent to New York City are part of one of the most urbanized and densely populated areas $(2,125$ persons per square mile) in the United States. Beginning in the 1970's, urbanization spread rapidly to the rural-suburban areas adjacent to the older cities and the rural character of the area disappeared (U.S. Water Resources Council, 1978). Despite urbanization, less than half ( 37 percent) of the Hackensack-Passaic HUC is characterized as urban land. Forested areas predominate in the Hackensack-Passaic HUC and help define the rural character of the western part of the study area in New Jersey. Small villages surrounded by forests, farmland, and pastures dominate the landscape of the study area in New York State (U.S. Environmental Protection Agency, unpub. data accessed May 3, 2000, on the World Wide Web at URL http://www.epa.gov/surf3/). The study area includes undeveloped land that includes parts of the watersheds of water-supply reservoirs in New Jersey and New York State. Extensive public lands lie within the study area, including Harriman State Park in New York State and Abram S. Hewitt State Forest, Great Swamp National Wildlife Refuge, Norvin Green State Forest, Ramapo Mountain Forest, Ringwood Manor State Park, Wanaque Wildlife Management Area, and Wawayanda State Park in New Jersey.

In 1995, the total population in the Hackensack-Passaic HUC was estimated to be 2.54 million. About 94 percent ( 2.38 million) of the total population was served by public suppliers; the balance of the population supplied their own water from wells. About 1.6 million people received publicly supplied water from water-supply reservoirs or river intakes, and about 800,000 received publicly supplied water from wells. Most of the population in the study area (91 percent) resides in New Jersey; the remainder ( 9 percent) resides in New York State (Solley and others, 1998).

\section{Hydrogeology}

The study area lies in two physiographic provinces, the Piedmont in the southeast and the New England (Highlands) in the northwest. The most productive aquifers in both physiographic provinces are the Wisconsin and pre-Wisconsin glacial-deposit aquifers. In the Piedmont Physiographic Province, aquifers of the Brunswick Group (Passaic Formation) are the most heavily used.

Low-yielding wells tap the Precambrian crystalline-rock aquifers, which consist of complex igneous and metamorphic rock throughout the Highlands Physiographic Province (Lyttle and Epstein, 1987). 


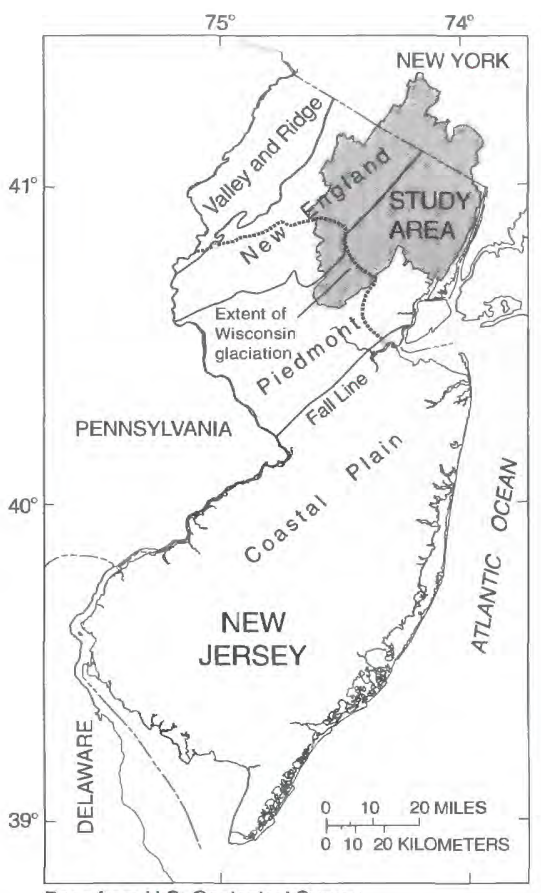

Base from U.S. Geological Survey digital line graph files, 1:24,000

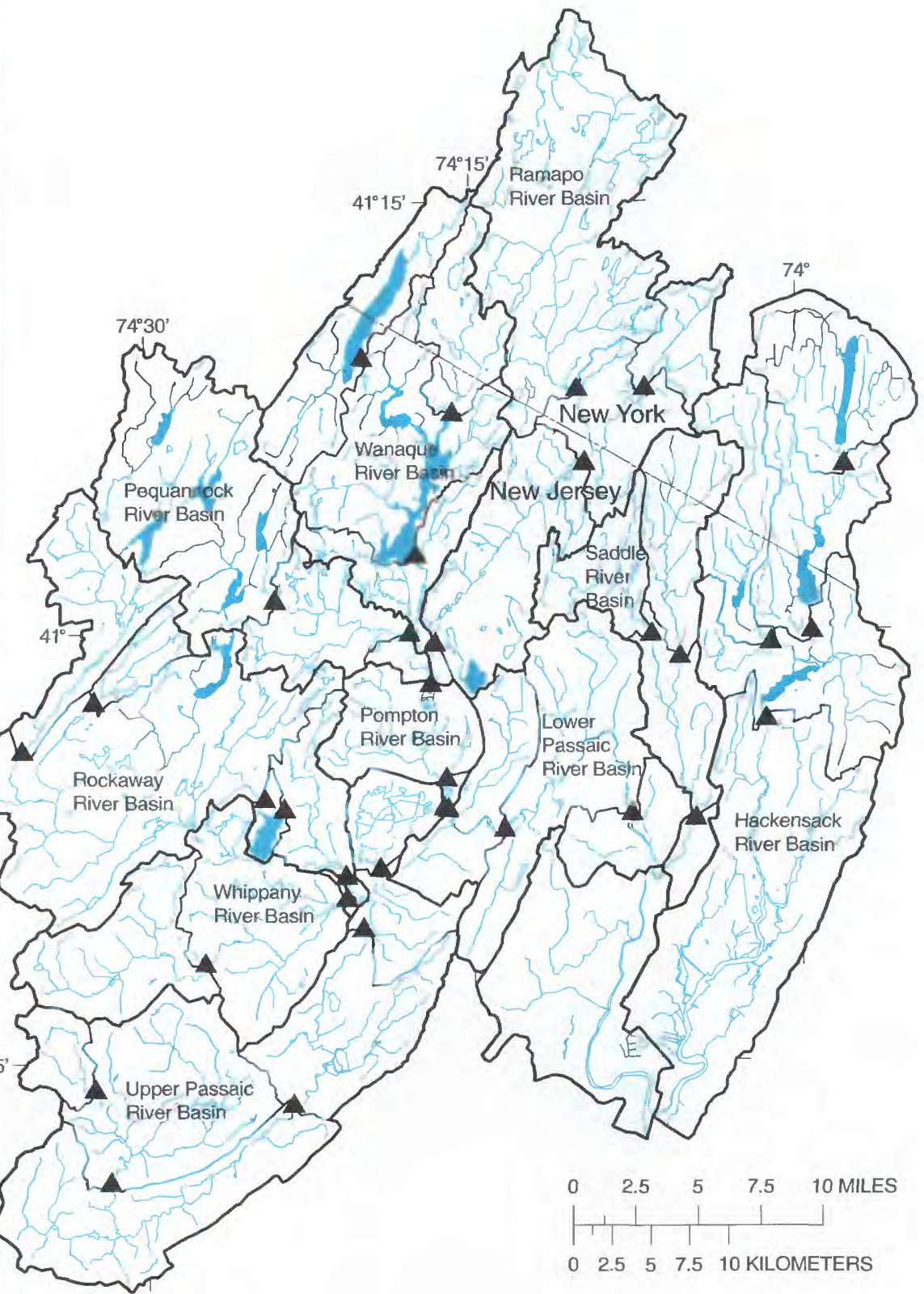

Base from Geological Survey digital data 1:100,000, 1983, Universal Transverse Mercator Projection, Zone 18

Reservoir

River or stream

Watershed boundary

Subwatershed boundary

A Streamflow-gaging station

Figure 1. Locations of the Passaic and Hackensack River Basins, major reservoirs, and 34 streamflow-gaging stations in New Jersey and New York. 
There are 1,287 total river miles in the Hackensack-Passaic HUC (U.S. Environmental Protection Agency, unpub. data accessed May 3, 2000, on the World Wide Web at URL http://www.epa.gov/ surf3/). The major tributaries to the Passaic and Hackensack Rivers are the Mahwah, Pequannock, Pompton, Ramapo, Rockaway, Saddle, Wanaque, and Whippany Rivers; Green Pond, Ho-Ho-Kus, and Pascack Brooks; and Ringwood Creek.

\section{Climate}

The climate of the study area varies from southeast to northwest because of differences in topography and the presence or absence of water bodies. Temperature in the Highlands area averages several degrees lower than in the Piedmont area in both summer and winter as a result of generally higher altitudes in the Highlands area. Precipitation is nearly uniform throughout the year and throughout the study area. The Highlands area receives more snowfall than the Piedmont area (Carswell and Rooney, 1976). The National Climatic Data Center (1993-97) reports New Jersey climatological data by three major divisions-Northern, Southern, and Coastal. The Northern division includes most of the study area (fig. 1). The average annual precipitation in the Northern division during 1961-90 was 48 in. (National Climatic Data Center, 1993-97).

Data on precipitation and temperature are reported by calendar year (National Climatic Data Center, 1993-97); however, climatological data in this report were compiled by water year (October 1-September 30). Therefore, references in this report to yearly values represent the water year. Precipitation in the Northern division during 1993 and 1995 was below the average annual (1961-90) precipitation of 48 in. by 3 in. in 1993 and by 13 in. in 1995, for annual precipitation values of 45 in. and 35 in., respectively (fig. 2). Precipitation during 1994 and 1996 was above the average annual precipitation by 5 in. in 1994 and 12 in. in 1996, for annual precipitation values of $53 \mathrm{in.}$ and $60 \mathrm{in}$., respectively.
The average annual temperature in the Northern division during $1961-90$ was $51{ }^{\circ} \mathrm{F}$. The average temperature was $51^{\circ} \mathrm{F}$ in $1993,52^{\circ} \mathrm{F}$ in 1995, and $50^{\circ} \mathrm{F}$ in 1994 and 1996 (fig. 3). The average temperature was $1{ }^{\circ} \mathrm{F}$ above the 30 -year mean in 1995 and $1^{\circ} \mathrm{F}$ below the 30 -year mean in 1994 and 1996. The average temperature in 1993 was equal to the average annual temperature in the Northern division during 1961-90.

\section{Major Water-Supply Features}

Most of the water-supply reservoirs in New Jersey lie within the study area. They include the Newark system in the Pequannock River Basin (Canistear, Charlotteburg, Clinton, Echo Lake, and Oak Ridge Reservoirs); the North Jersey District Water Supply Commission system in the Wanaque River Basin (Monksville and Wanaque Reservoirs); the Jersey City system in the Rockaway River Basin (Boonton and Splitrock Reservoirs); and the United Water system in the Hackensack River Basin (De Forest Lake, Lake Tappan, Oradell, and Woodcliff Lake Reservoirs).

The effects of a small number of large (highvolume) withdrawals and discharges in the study area on the observed streamflow are greater than those of a large number of small (low-volume) withdrawals and discharges, with few exceptions. A site was considered to be "high- volume" if the average (1993-96) withdrawal or discharge was greater than about $0.6 \mathrm{Mgal} / \mathrm{d}\left(1 \mathrm{ft}^{3} / \mathrm{s}\right)$. Average withdrawals exceed $0.6 \mathrm{Mgal} / \mathrm{d}$ at about 19 surface-water sites in the study area (fig. 4). These include both withdrawals for public supply and transfers to other locations within the Passaic and Hackensack River Basins. The largest average surface-water withdrawals are from the Wanaque Reservoir (129 Mgal/d (200 ft $3 / \mathrm{s})$ ), Oradell Reservoir (101 Mgal/d $\left.\left(156 \mathrm{ft}^{3} / \mathrm{s}\right)\right)$, Boonton Reservoir (45.8 $\left.\mathrm{Mgal} / \mathrm{d}\left(70.8 \mathrm{ft}^{3} / \mathrm{s}\right)\right)$, and Charlotteburg Reservoir $\left(43.9 \mathrm{Mgal} / \mathrm{d}\left(67.9 \mathrm{ft}^{3} / \mathrm{s}\right)\right)$. At the Two Bridges Pumping Station, water is transferred by the North Jersey District Water Supply Commission, United Water New Jersey, and Passaic Valley Water

\footnotetext{
${ }^{1}$ A water year is designated by the calendar year in which it ends. Therefore, water year 1993 extends from October 1,1992 , through September 30, 1993.
} 


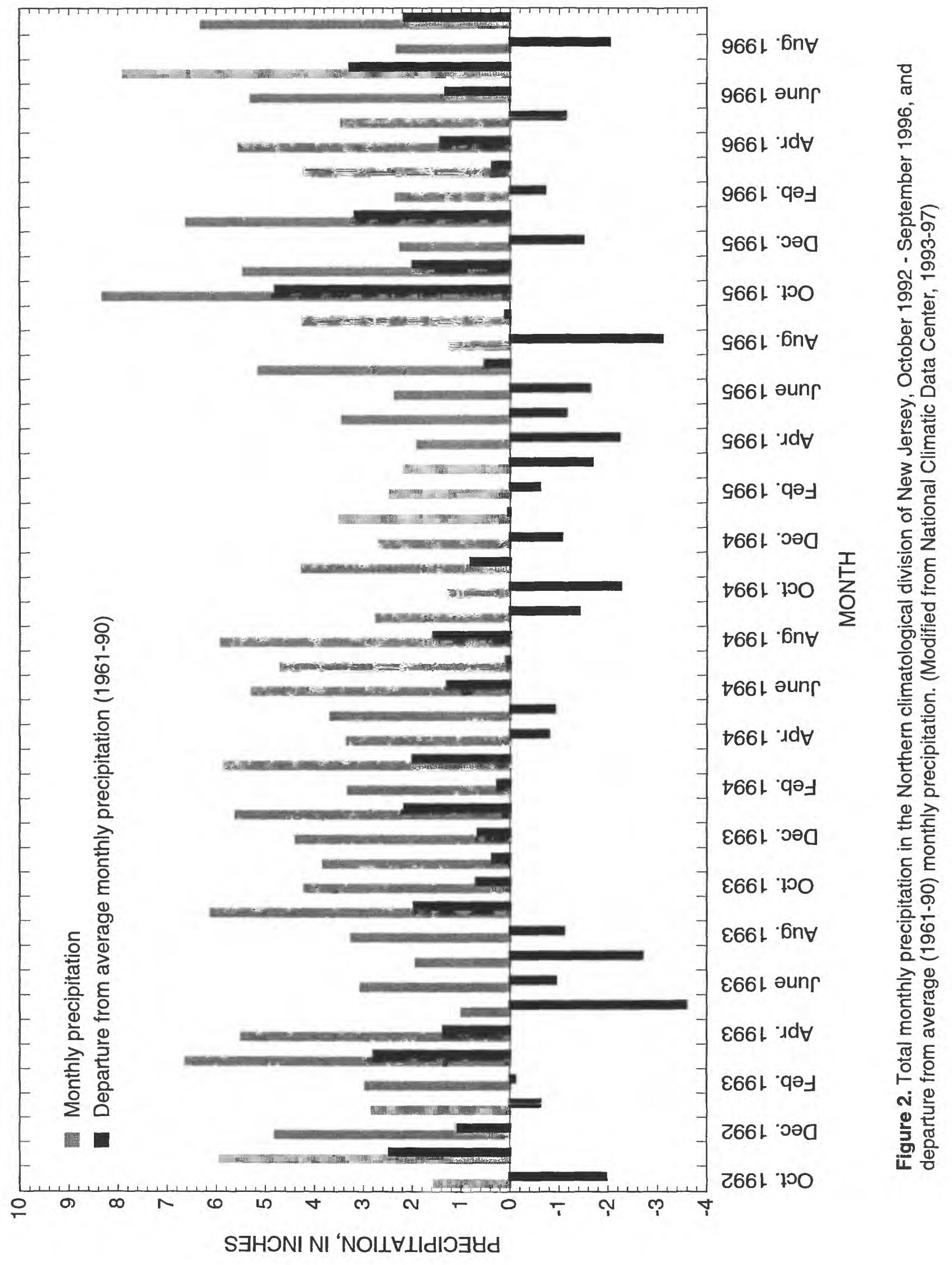




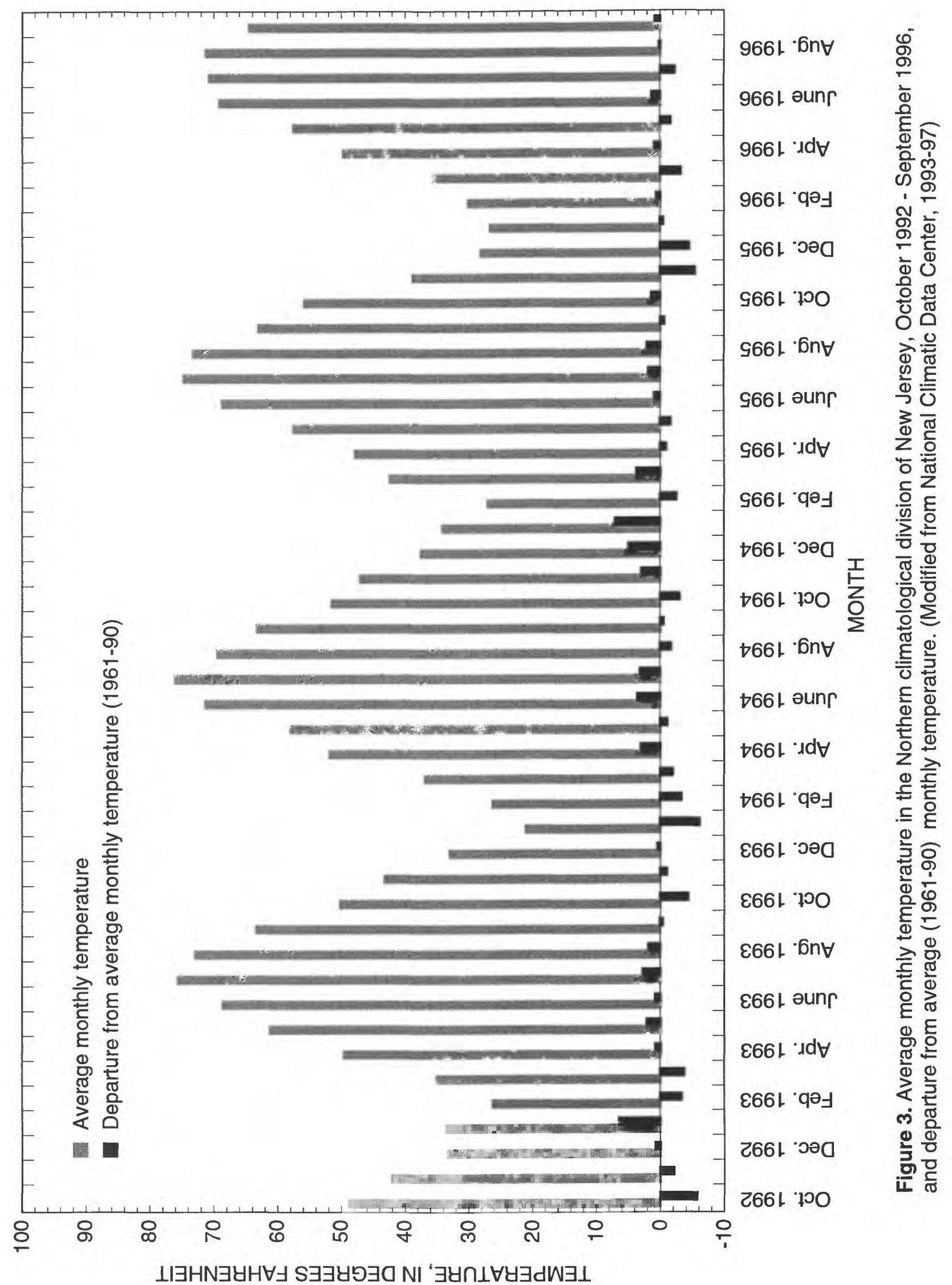




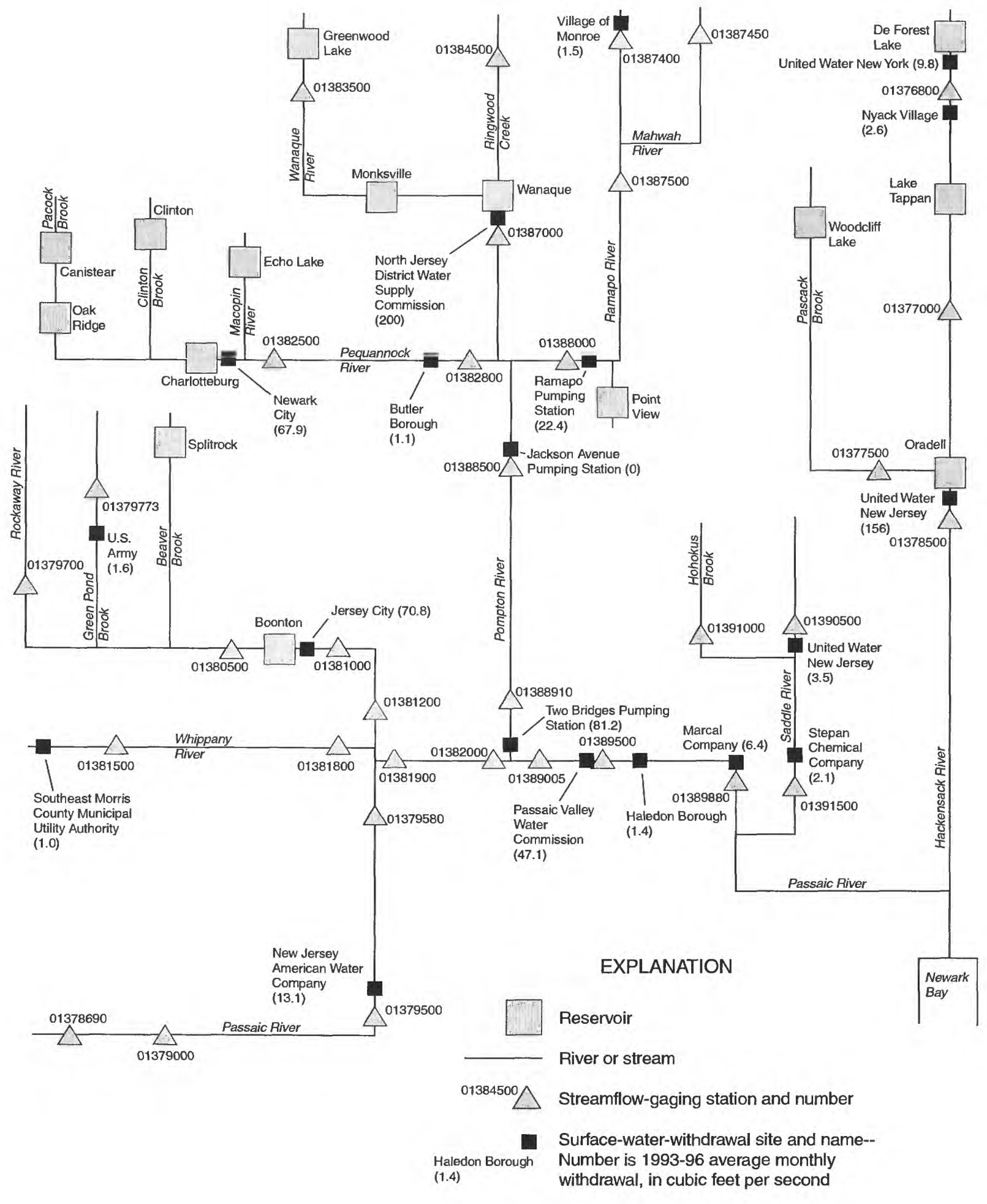

Figure 4. Schematic diagram showing relation of high-volume surface-water-withdrawal sites in subwatersheds to streamflow-gaging stations and water-supply reservoirs, Passaic and Hackensack River Basins, New Jersey and New York. 
Commission to either the Wanaque or Oradell Reservoir or to treatment facilities for public supply.

An average of $14.5 \mathrm{Mgal} / \mathrm{d}\left(22.4 \mathrm{ft}^{3} / \mathrm{s}\right)$ is transferred from the Ramapo Pumping Station on the Ramapo River to the Wanaque Reservoir. About 2.3 Mgal $/ \mathrm{d}\left(3.5 \mathrm{ft}^{3} / \mathrm{s}\right)$ is transferred from the Saddle River to the Oradell Reservoir by United Water New Jersey. New Jersey American Water Company transfers an average of $8.5 \mathrm{Mgal} / \mathrm{d}\left(13.1 \mathrm{ft}^{3} / \mathrm{s}\right)$ from the Passaic River and Canoe Brook to the Canoe Brook Reservoirs. (Although this withdrawal is shown in figure 4, the Canoe Brook Reservoirs are not shown because they were not included in the change-in-storage calculation (farther on)).

Surface water from outside the study area is transferred into the Hackensack River Basin from several sites, including Hirschfield Brook, a tributary to the Hackensack River located just downstream from Oradell Reservoir, and the Sparkill River in the Hudson River Basin. These transfers are small, averaging $0.4 \mathrm{Mgal} / \mathrm{d}\left(0.6 \mathrm{ft}^{3} / \mathrm{s}\right)$ and 0.06 $\mathrm{Mgal} / \mathrm{d}\left(0.1 \mathrm{ft}^{3} / \mathrm{s}\right)$, respectively, during water years 1993-96. Most of the surface water that is withdrawn within the study area is returned to surface water--to Newark and New York Bays or the Lower Passaic River--through treatment facilities outside the study area.

Most of the high-volume point-source discharges in the study area are from municipal treatment facilities and are located in the Passaic, Rockaway, Saddle, and Whippany River Basins. Average discharges exceed $0.6 \mathrm{Mgal} / \mathrm{d}\left(1 \mathrm{ft}^{3} / \mathrm{s}\right)$ at about 33 point-source discharge sites in the study area (fig. 5). Most of the ground water that is withdrawn within the study area is returned to surface water through treatment facilities within the study area.

Streamflow in several subwatersheds in the Passaic River Basin is affected by a high density of large-volume public-supply wells. These subwatersheds include the Upper Passaic River Basin between stations 01379580 (Passaic River near Hanover Neck, N.J.) and 01379500 (Passaic River near Chatham, N.J.), where ground-water withdrawals averaged $22 \mathrm{Mgal} / \mathrm{d}\left(34 \mathrm{ft}^{3} / \mathrm{s}\right.$ ) during 1993 96; the Whippany River Basin between stations
01381800 (Whippany River at Morristown, N.J.) and 01381500 (Whippany River near Pine Brook, N.J.), where withdrawals averaged $17 \mathrm{Mgal} / \mathrm{d}$ (27 $\mathrm{ft}^{3} / \mathrm{s}$ ); and the Ramapo River Basin between station 01387500 (Ramapo River near Mahwah, N.J.) and two upstream stations, 01387400 (Ramapo River at Ramapo, N.Y.) and 01387450 (Mahwah River near Suffern, N.Y.), where withdrawals averaged 15 $\mathrm{Mgal} / \mathrm{d}\left(23 \mathrm{ft}^{3} / \mathrm{s}\right)$. Average ground-water withdrawals were $9 \mathrm{Mgal} / \mathrm{d}\left(14 \mathrm{ft}^{3} / \mathrm{s}\right)$ both from the Rockaway River Basin between station 01380500 (Rockaway River above reservoir at Boonton, N.J.) and two upstream stations, 01379700 (Rockaway River at Berkshire Valley, N.J.) and 01379773 (Green Pond Brook at Picatinny Arsenal, N.J.), and from the Lower Passaic River Basin between stations 01389500 (Passaic River at Little Falls, N.J.) and 01389880 (Passaic River at Route 46 at Elmwood Park, N.J.). Average withdrawals from all wells in 20 of the 34 subwatersheds in the study area exceeded $0.6 \mathrm{Mgal} / \mathrm{d}\left(1 \mathrm{ft}^{3} / \mathrm{s}\right)$ during 1993-96 (fig. 6).

\section{Previous Investigations}

This study is a continuation of previous work done to develop reconstructed-streamflow records for streamflow-gaging stations in the Passaic River Basin. Clinton Bogert Associates (unpublished consultant's report, 1982) reconstructed streamflow records for the 60-year period from October 1, 1919, through September 30, 1979. Daily reconstructed-streamflow values for 11 USGS streamflow-gaging stations and two control points were calculated by adjusting observed streamflow on the basis of surface-water withdrawals and reservoirstorage changes. These values were then used in a computer simulation to apply the effects of discharges from municipal wastewater-treatment facilities throughout the basin, as well as the effect of industrial discharges in the lower reaches of the basin, to reconstruct flows. Lawler, Matusky, and Skelly Engineers (unpublished consultant's report, 1997) extended this simulation from October 1 , 1978, through September 30, 1993. This later effort added point-source discharge data for treatment facilities within the watershed to the reconstructedstreamflow data set, as well as adding several newstreamflow stations and control points to the model. These models were used in the develop- 


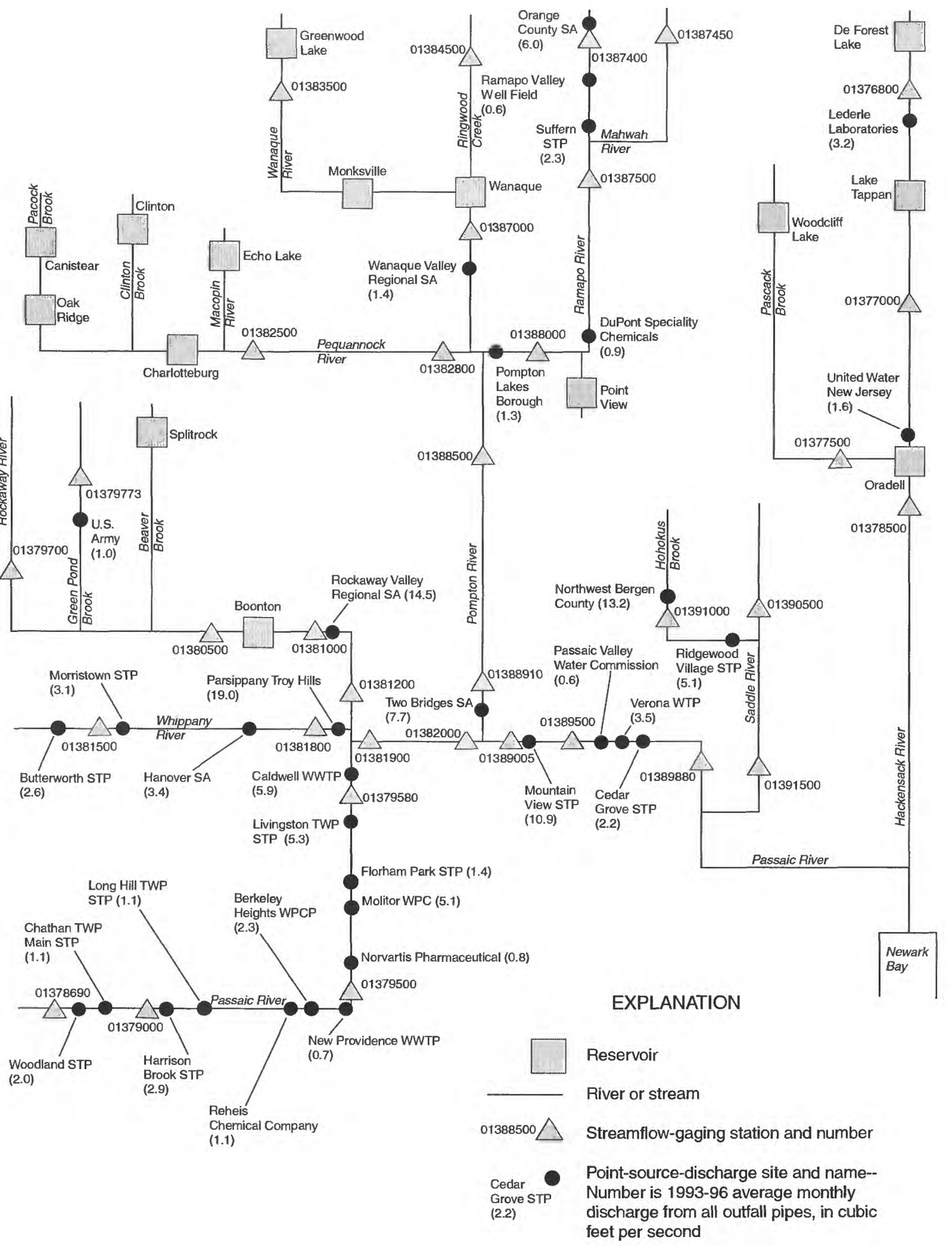

Figure 5. Schematic diagram showing relation of high-volume point-source-discharge sites in subwatersheds to streamflow-gaging stations and water-supply reservoirs, Passaic and Hackensack River Basins, New Jersey and New York. (SA, sewerage authority; STP, sewage-treatment plant; TWP, township; WPC, water-pollution control; WPCP, water-pollution-control plant; WTP, waste-treatment plant; WWTP, wastewater-treatment plant) 


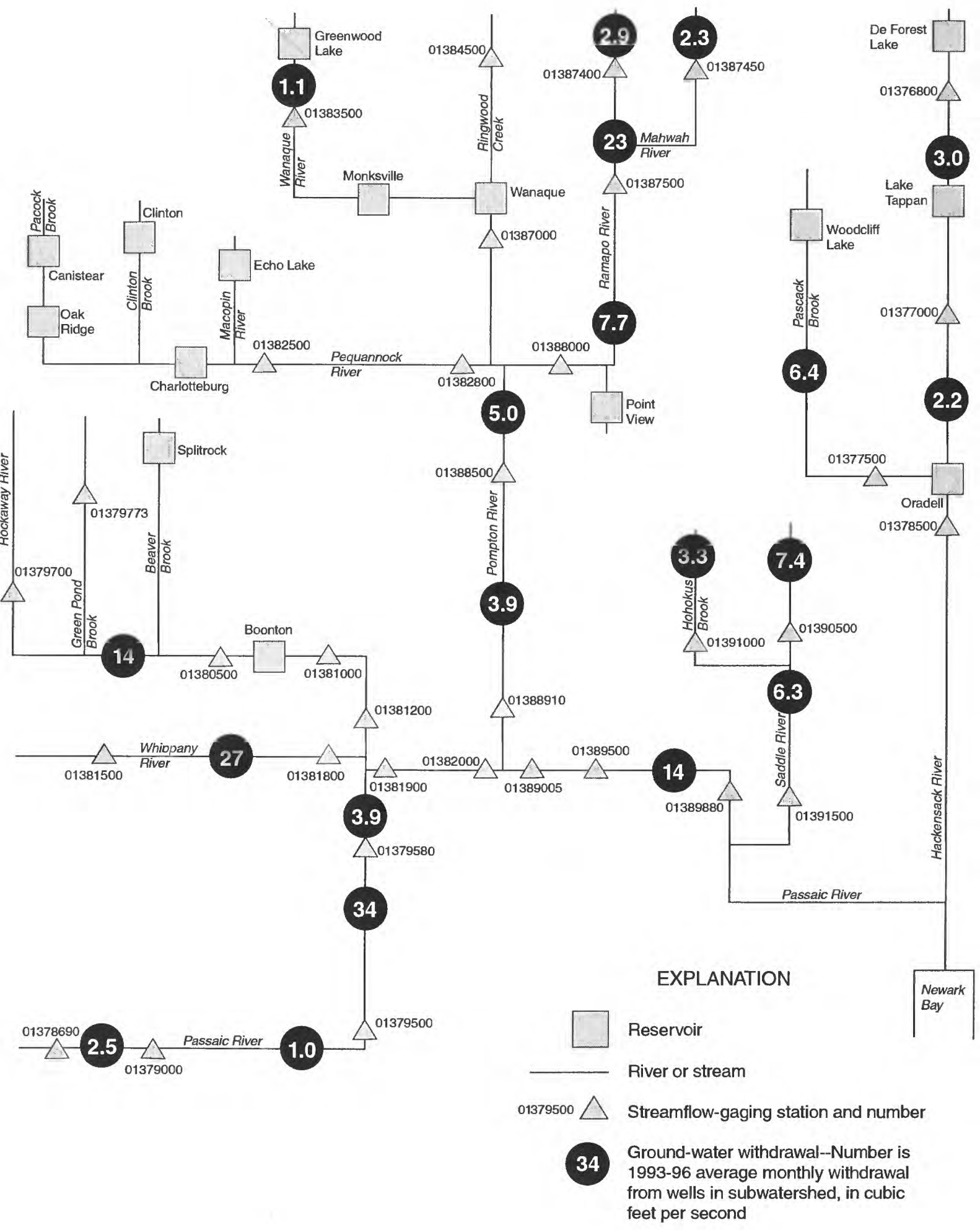

Figure 6. Schematic diagram showing subwatersheds from which average ground-water withdrawals exceed 1 cubic foot per second, Passaic and Hackensack River Basins, New Jersey and New York. 
ment of operation schemes and storage-management plans for the Wanaque South project, a regional water-supply project that provided an additional $79 \mathrm{Mgal} / \mathrm{d}\left(122 \mathrm{ft}^{3} / \mathrm{s}\right)$ to the water supply for northern New Jersey.

Several ground-water-flow models have been developed to describe ground-water-flow conditions in northern New Jersey. Gordon (1993) used a ground-water-flow model to simulate and quantify the effects of current and predicted withdrawals on the ground-water-flow system under steady-state conditions. J.L. Hoffman (New Jersey Geological Survey, written commun., 1997) used a numerical model to simulate ground-water-flow paths in the central Passaic River Basin under historical and projected pumpage conditions. Nicholson and others (1996) used a finite-difference model to simulate ground-water flow in three aquifers and two intervening confining units in a carbonate-rock and valley-fill aquifer system in the New Jersey Highlands. Voronin and Rice (1996) used a three-dimensional finite-difference model to simulate ground-water flow under steady-state pumping conditions in glacial and bedrock aquifers at Picatinny Arsenal, New Jersey. Hill and others (1992) used a three-dimensional numerical model to quantify hydrogeologic characteristics of the ground-water system and to evaluate the hydrologic relation between ground-water withdrawals and streamflow in valley-fill deposits in the Ramapo River Valley. Dunne and Tasker (1996) developed a continuity-accounting computer model of the Raritan River Basin water-supply system, which can be used to evaluate the effects of alternative patterns of operation of the water-supply system during extended periods of below-average precipitation.

Reports that document the geology underlying the study area include a map of the Newark $1^{0} \times 2^{0}$ Quadrangle, New Jersey, Pennsylvania, and New York (Lyttle and Epstein, 1987); a map of the Green Pond Mountain region from Dover to Greenwood Lake, New Jersey (Herman and Mitchell, 1991); a bedrock geologic map of northern New Jersey (Drake and others, 1996); and a description of the hydrogeologic character and thickness of glacial sediments in New Jersey (Stanford and others, 1990).

Zripko and Hasan (1994) present an inventory of depletive water use for 23 regional waterresource planning areas of New Jersey. This report identifies water and wastewater transfers among planning areas and lists the average annual groundand surface-water withdrawals and wastewater discharges during 1986-88. Carswell and Rooney (1976) describe the ground-water resources and geology of Passaic County. Vecchioli and Miller (1973) describe the hydrology of the New Jersey part of the Ramapo River Basin and evaluate the feasibility of developing large ground-water supplies from the stratified drift in the Ramapo River valley by inducing recharge to the aquifer from the river. Schopp and Bauersfeld (1986) summarize the surface-water resources of New Jersey. Nawyn (1998) compiles monthly withdrawal data for ground-water and surface-water sites in New Jersey capable of providing 100,000 gallons per day or more.

Hickman (1997) used statistical tests to analyze water-quality measurements in the Passaic and Pompton Rivers to identify differences between water quality on days of diversion at the Two Bridges pumping station and water quality on days of no diversion. Price and Schaefer (1995) used contemporaneous-streamflow estimates to calculate instream loads from selected constituent concentrations in water-quality samples for stations in the Rockaway and Whippany Basins. Loads from permitted point sources upstream from each station were estimated. Czarnik and Kozinski (1994) characterize the regional ground-water quality of the central Passaic River Basin. Samples from wells open to three principal aquifer systems--glacial sediments, sedimentary bedrock, and igneous bedrock--were analyzed. Buxton and others (1998) present relations of water quality to streamflow determined for 18 constituents at stations in the Passaic and Hackensack River Basins. Surfacewater quality and streamflow data were evaluated for trends in constituent concentrations during high and low flow. Hickman (1999) conducted trend tests on values of 24 water-quality characteristics measured at 83 surface-water-quality stations on streams in New Jersey during water years 1986-95. 


\section{Acknowledgments}

The authors extend their appreciation to Paul Schorr of the NJDEP Bureau of Safe Drinking Water, Asghar Hasan of the NJDEP Bureau of Water Allocation, and Robert Schopp of the USGS for their guidance in the planning and implementation of this investigation. Thanks also are due to members of the NJDEP Technical Advisory Committee, including Pen Tao of United Water New Jersey, Jeffrey Hoffman of the New Jersey Geological Survey, and Keith Pytlik of North Jersey District Water Supply Commission. The contributions of the many individuals from water-supply and sewage authorities who provided data for this study, including Philip Roosa of the Passaic Valley Water Commission, Donald Distante of United Water New York, Roger Vann of the U.S. Environmental Protection Agency (USEPA), and Edward Simms of Orange County Health Department, also are appreciated.

\section{SOURCES, ESTIMATION, AND DESCRIPTION OF DATA USED TO RECONSTRUCT STREAMFLOW RECORDS}

Streamflow and other hydrologic data were compiled from the computerized data bases of the USGS, NJDEP, and USEPA, as well as from paper files and published reports of the USGS and NJDEP. In addition, some monthly and daily data were collected directly from public and private water suppliers and wastewater-treatment facilities. The daily data set was developed as a test to determine the feasibility of reconstructing daily streamflow records on the basis of availablata. Missing data were estimated by using methods developed for this and other studies. Site-specific data were stored in a geographic information system (GIS) as an $A R C / I N F O^{2}$ point coverage and in related point attribute tables.

Data compiled as part of this study include observed streamflow at 34 USGS streamflow-gaging stations, reservoir level or reservoir storage in
15 reservoirs, surface-water withdrawals at 87 intakes, discharges from 265 public and private treatment facilities that include 368 outfall pires (pl. 1), and ground-water withdrawals from about 840 wells (pl. 2). After they were compiled, the data were formatted, converted to units of cubic feet per second, and read into an Excel $^{2}$ spreadsheet. Observed-streamflow records were used as the starting point from which to calculate reconstructed streamflow.

\section{Streamflow}

Observed-streamflow data were compiled for 34 streamflow-gaging stations in the Passaic and Hackensack River Basins in New Jersey and New York (table 1). These gaging stations include most of the continuous-record streamflow-gaging stations in the study area that are operated by the USGS, as well as selected low-flow partial-record, miscellaneous, and discontinued streamflow-gaging stations. Stations were selected to provide an even distribution of stations throughout the study area, and to ensure the inclusion of stations in areas with major water-supply features, such as large reservoirs and high-volume surface-water withdrawals or point-source discharges. Continuous records for the entire study period of October 1, 1992, through September 30, 1996, were available for 24 of the 34 stations used in this study. Partial records were available for one continuous-record station and one discontinued station. Missing streamflow records for these stations and the remaining eight partial-record and discontinued stations were estimated by using one or a combination of the mothods described below. Active USGS continuousrecord gaging stations in the study area were $r$ t used if they were located near other active cortinuous-record stations or if the reliability of their records was questionable. Stations not used are stations 01379780 (Green Pond Brook below Picatinny Lake, at Picatinny Arsenal, N.J.), 01379790 (Green Pond Brook at Wharton, N.J.), 01381400 (Whippany River near Morristown, N.J.), and 01387520 (Ramapo River at Suffern, N.Y.).

\footnotetext{
${ }^{2}$ The use of brand or trade names in this report is for identification purposes only and does not constitute endorsement by the U.S. Geological Survey.
} 
Table 1. Streamflow-gaging stations used in the study and associated information

[USGS, U.S. Geological Survey; CR, continuous-record streamflow-gaging station; DIS, discontinued streamflow-gą̧ing station, LFPR, low-flow partial-record station; MISC, miscellaneous station; QW, water-quality station; MOVE1, mainte "ance-ofvariance extension type 1; DAR, drainage-area ratio; --, no estimation required]

\begin{tabular}{|c|c|c|c|c|c|}
\hline $\begin{array}{c}\text { USGS } \\
\text { streamflow- } \\
\text { gaging- } \\
\text { station } \\
\text { number }\end{array}$ & Station name & $\begin{array}{l}\text { Drainage } \\
\text { area, in } \\
\text { square } \\
\text { miles }\end{array}$ & $\begin{array}{l}\text { Type of } \\
\text { station }\end{array}$ & $\begin{array}{l}\text { Method used } \\
\text { to estimate } \\
\text { observed } \\
\text { streamflow }\end{array}$ & $\begin{array}{c}\text { Period for } \\
\text { which } \\
\text { streamflow } \\
\text { was } \\
\text { estimated }\end{array}$ \\
\hline 01376800 & Hackensack River at West Nyack, N.Y. & 30.7 & $\mathrm{CR}$ & -- & -- \\
\hline 01377000 & Hackensack River at Rivervale, N.J. & 58 & $\mathrm{CR}, \mathrm{QW}$ & .. & -- \\
\hline 01377500 & Pascack Brook at Westwood, N.J. & 29.6 & $\mathrm{CR}$ & -- & .- \\
\hline 01378500 & Hackensack River at New Milford, N.J. & 113 & $\mathrm{CR}$ & .- & -- \\
\hline 01378690 & Passaic River near Bernardsville, N.J. & 8.83 & DIS & ESTWAT & $1993-96$ \\
\hline 01379000 & Passaic River near Millington, N.J. & 55.4 & CR, QW & -- & -- \\
\hline 01379500 & Passaic River near Chatham. N.J. & 100 & CR, QW & .- & -- \\
\hline 01379580 & Passaic River near Hanover Neck, N.J. & 132 & MISC & MOVE1, DAR & 1993-96 \\
\hline 01379700 & Rockaway River at Berkshire Valley, N.J. & 24.4 & DIS & ESTWAT & $7 / 96-9 / 96$ \\
\hline 01379773 & Green Pond Brook at Picatinny Arsenal, N.J. & 7.65 & CR & - & -- \\
\hline 01380500 & Rockaway River above reservoir at Boonton, N.J. & 116 & $\mathrm{CR}, \mathrm{QW}$ & -- & -- \\
\hline 01381000 & Rockaway River below reservoir at Boonton, N.J. & 119 & CR & -- & -- \\
\hline 01381200 & Rockaway River at Pine Brook, N.J. & 136 & LFPR, QW & DAR & 1993-96 \\
\hline 01381500 & Whippany River at Morristown, N.J. & 29.4 & $\mathrm{CR}, \mathrm{QW}$ & -- & \\
\hline 01381800 & Whippany River near Pine Brook, N.J. & 68.5 & LFPR, QW & DAR & $1993-96$ \\
\hline 01381900 & Passaic River at Pine Brook, N.J. & 349 & $\mathrm{CR}$ & .- & -- \\
\hline 01382000 & Passaic River at Two Bridges, N.J. & 361 & LFPR, QW & DAR & $1993-96$ \\
\hline 01382500 & Pequannock River at Macopin Intake Dam, N.J. & 63.7 & $\mathrm{CR}, \mathrm{QW}$ & -- & -. \\
\hline 01382800 & Pequannock River at Riverdale, N.J. & 83.9 & $\mathrm{CR}$ & ESTWAT & 1993 \\
\hline 01383500 & Wanaque River at Awosting, N.J. & 27.1 & $\mathrm{CR}$ & - & -- \\
\hline 01384500 & Ringwood Creek near Wanaque, N.J. & 19.1 & $\mathrm{CR}$ & .- & -- \\
\hline 01387000 & Wanaque River at Wanaque, N.J. & 90.4 & $\mathrm{CR}$ & -- & -- \\
\hline 01387400 & Ramapo River at Ramapo, N.Y. & 86.9 & $\mathrm{CR}$ & -- & -- \\
\hline 01387450 & Mahwah River near Suffern, N.Y. & 12.3 & $\mathrm{CR}$ & -- & -- \\
\hline 01387500 & Ramapo River near Mahwah, N.J. & 120 & CR, QW & - & -- \\
\hline 01388000 & Ramapo River at Pompton Lakes, N.J. & 160 & $\mathrm{CR}, \mathrm{QW}$ & -- & -- \\
\hline 01388500 & Pompton River at Pompton Plains, N.J. & 355 & $\mathrm{CR}$ & -- & -- \\
\hline 01388910 & Pompton River at Mountain View, N.J. & 371 & MISC & MOVE1, DAR & $1993-96$ \\
\hline 01389005 & Passaic River below Pompton River at Two Bridges, N.J. & 734 & MISC, QW & ESTWAT & $1993-96$ \\
\hline 01389500 & Passaic River at Little Falls N.J. & 762 & CR, QW & 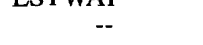 & - \\
\hline 01389880 & Passaic River at Rt 46 at Elmwood Park, N.J. & 803 & MISC, QW & MOVE1, DAR & $1993-96$ \\
\hline 01390500 & Saddle River at Ridgewood. N.J. & 21.6 & CR, OW & the & -- \\
\hline 01391000 & Hohokus Brook at Ho-Ho-Kus, N.J. & 16.4 & CR & -- & -- \\
\hline 01391500 & Saddle River at Lodi, N.J. & 54.6 & CR, QW & -- & -- \\
\hline
\end{tabular}




\section{Measured Values}

Monthly mean observed streamflow values for October 1992 through September 1996 and daily mean observed streamflow for May 1, 1995, through October 31, 1995, for 24 continuousrecord streamflow-gaging stations were retrieved from the USGS National Water Information System (NWIS) Automated Data Processing System (ADAPS) data base. These data were then entered into a spreadsheet and used as a starting point from which to calculate monthly and daily reconstructed streamflow. Observed monthly and daily values for these stations are published annually by the USGS in water-resources data reports (Bauersfeld and others, 1994, 1995; Reed and others, 1996, 1997).

\section{Estimation of Data}

Streamflow records at partial-record, miscellaneous, and discontinued stations and missing records at continuous-record stations were estimated with standard USGS techniques by using values from nearby gages. Daily streamflow records were estimated by using one of the following techniques: (1) ESTWAT, a USGS computer program; (2) Maintenance of Variance Extension, Type 1 (MOVE1) (Hirsch, 1982); and (3) drainagearea ratio. Streamflow records calculated by using these techniques are called "observed streamflow records" in this report. For several stations, a combination of these methods was used to estimate streamflow records. For example, records for station 01382800, Pequannock River at Riverdale, N.J., were retrieved from the ADAPS data base for water years 1994-96 and ESTWAT was used to estimate those for 1993. Records for station 01381200, Rockaway River at Pine Brook, N.J., were estimated by using a drainage-area ratio to estimate local inflow between stations 01381200 and 01381000 (Rockaway River below reservoir at Boonton, N.J.), then adding the discharge at 01381000 and the discharge from the Rockaway Valley Regional Sewerage Authority. Daily streamflow values were then used to calculate monthly mean streamflow records.

In the ESTWAT method, streamflow is estimated by correlating log-transformed streamflow values at discontinued stations to streamflow records at nearby continuous-record stations by using multiple-regression techniques. The continuous-record stations used in these estimates were selected on the basis of similarities in basin characteristics, the reliability of the record, and proximity to the discontinued station. ESTWAT was used to estimate streamflow at discontinued stations and at one continuous-record station for which records for the 1993-96 period were incomplete. ESTWAT can use data from multiple stations to estimate streamflow at discontinued stations. Values (slope of the line and $y$-intercept) are set to minimize squared errors. Streamflow at the continuous-record stations also can be "time-lagged" to improve the estimates of streamflow at discontinued stations.

In the MOVE1 method, instantaneous lc ' $\mathrm{V}$ flow streamflow measurements at the partialrecord and miscellaneous stations are correlated with concurrent mean daily discharge at a nearby continuous-record gaging station to estimate streamflow at the partial-record or miscellaneous station. This method is a modification of linear least-squares regression in which values are set to maintain the sample mean and variance rather than to minimize squared errors (Hirsch, 1982). The best-fit line is drawn through data points that represent the relation between discharge at a partialrecord station and mean daily discharge at a continuous-record station. The equation of this line is then used to estimate discharge at the partial-re?ord station on the basis of the discharge measured at the continuous-record station.

In the drainage-area ratio method, streamflow at partial-record streamflow stations is estimated from observed streamflow at an adjacert continuous-record station with similar basin cl aracteristics and reliable records. Values at conti uous-record stations were adjusted to account for differences in the drainage areas of the two stations. Each value at the continuous-record stat:on was multiplied by a coefficient that represents the ratio of the size of the drainage basin of the partialrecord station to the size of the drainage basin of the continuous-record station to estimate streamflow at the partial-record station.

After the daily values were determined for each partial-record and discontinued station, the 
monthly mean was calculated from the daily records. These values were then entered into monthly and daily spreadsheets to calculate reconstructed streamflow. The equations used to estimate streamflow records at all stations with missing or incomplete records are shown in table 2.

\section{Reliability of Data}

The accuracy of streamflow records depends on the stability of the stage-discharge relation, the frequency of streamflow measurements, the accuracy of the measurements of stage and discharge, and the interpretation of records (Reed and others, 1997). Streamflow records from continuous-record stations generally are highly reliable because they are based on periodic measurements made to verify the stage-discharge relation.

Many factors can affect the accuracy of streamflow measurements at continuous-record streamflow-gaging stations. Accurate measurement requires that equipment is properly assembled and maintained in good condition. The characteristics of the measurement section also affect measurement accuracy. The section should be deep enough to permit use of the 2-point method of measuring velocity. Inaccuracies in sounding can occur in sections that are very deep or where water is flowing very fast. The presence of bridge piers in or near the section affects the distribution of velocities across the channel. Twenty-five to 30 vertical sections typically are required and ideally are spaced so that each section contains approximately the same amount of discharge. If the stage is changing rapidly during the measurement, the correct gage height to apply to the streamflow value is uncertain. Other factors that may affect the accuracy of measurements include the presence of ice in the measuring section; wind, which may obscure the angle of the current by creating waves that make it difficult to sense the water surface prior to sounding and by changing the velocity of the water at shallow depths; datum changes; faulty intake operation; float leakage; and float-tape slippage (Rantz, 1982).

Continuous records of streamflow are computed from the record of stage and the stage-discharge relation. The accuracy of individual gage observations typically is within $0.02 \mathrm{ft}$ (Rantz, 1982). Several factors can affect the accurany of the stage record. The accuracy of float-operated recorders may be affected by float lag, which varies directly with the force required to move the mechanism of the recorder and inversely with the square of the float diameter. Line shift may affect the accuracy of stage records. As the stage changes, the weight of the float tape changes the depth of flotation of the float. The magnitude of the change depends on the magnitude of the change in the stage. Submergence of the counterweight also can affect accuracy. When a counterweight and part of the float tape become submerged as the stage rises, the pull on the float is reduced and its depth of flotation increases. The accuracy of bubble gages may be affected by variations in gas friction, variations in required bubble-feed rate, with rate of increase in stage, and variations in the weight of the gas column with stage, sediment deposits on bubble orifices, and leaks in the system (Rantz, 1982).

The accuracy of continuous records generally is within 15 percent of the true value 95 percent of the time (Bauersfeld and others, 19?4, 1995; Reed and others, 1996, 1997), but thore are some exceptions. Records from the Passaic River at Pine Brook generally were within 15 percent of the true value when streamflow was less th $₹ 1,000$ $\mathrm{ft}^{3} / \mathrm{s}$ and not within 15 percent when streamflow equaled or exceeded $1,000 \mathrm{ft}^{3} / \mathrm{s}$. Records from Saddle River at Ridgewood were within 15 percent of the true value except during 1995, when thoy were different from the true value by more than 15 percent.

Streamflow records estimated by using MOVE1, ESTWAT, and drainage-area ratio methods are less accurate than recorded streamflow data. The accuracy of estimates of streamflow at these stations depends in part on the accurs cy and quantity of the streamflow data available for the stations used in the estimate, and similaritios in basin characteristics. Estimates of mean daily streamflow made by using ESTWAT generally are more accurate than estimates made by using other methods because ESTWAT uses actual records from other time periods to establish the relation used to make the estimate; errors generally are 
Table 2. Equations used to estimate observed streamflow at stations with missing or incomplete records, Passaic and Hackensack River Basins, New Jersey and New York

[Number in parentheses after station number represents the number of days of lag applied to daily streamflow values used to calculate estimated streamflow values. A positive number represents the number of days before the date of the estimated value; a negative number represents the number of days after the date of the estimated value; USGS, U.S. Geological Survey; $Q_{m}$, obsarved streamflow; $\mathbf{Q}_{\mathrm{ps}}$, point-source discharge; RVRSA, Rockaway Valley Regional Sewerage Authority]

\begin{tabular}{|c|c|}
\hline $\begin{array}{c}\text { USGS } \\
\text { streamflow- } \\
\text { gaging- } \\
\text { station } \\
\text { number }\end{array}$ & Equation \\
\hline \multirow[t]{2}{*}{01378690} & 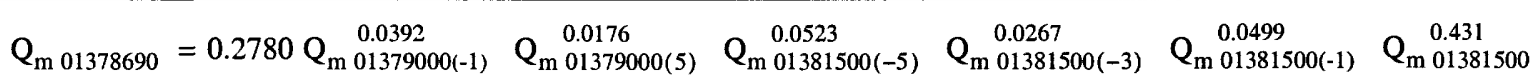 \\
\hline & $\begin{array}{llllll}\mathrm{Q}_{\mathrm{m} 01381500(3)}^{0.0456} & \mathrm{Q}_{\mathrm{m} 01380500(-5)}^{-0.0209} & \mathrm{Q}_{\mathrm{m} 01380500(3)}^{-0.043} & \mathrm{Q}_{\mathrm{m} 01398500}^{0.558} & \mathrm{Q}_{\mathrm{m} 0139850(1)}^{-0.155} & \mathrm{Q}_{\mathrm{m} 01398500(5)}^{0.0338}\end{array}$ \\
\hline 01379580 & $\mathrm{Q}_{\mathrm{m} 01379580}=1.031\left(1.604 \mathrm{Q}_{\mathrm{m} 01379500}^{0.9542}\right)$ \\
\hline \multirow[t]{2}{*}{01379700} & 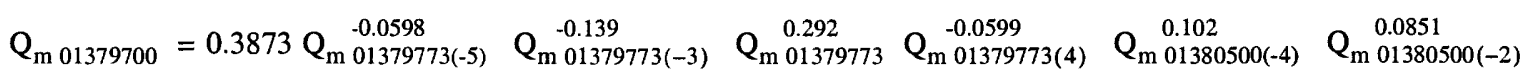 \\
\hline & $\mathrm{Q}_{\mathrm{m} 01380500}^{0.47} \mathrm{Q}_{\mathrm{m} 01380500(2)}^{0.142} \mathrm{Q}_{\mathrm{m} 01380500(5)}^{0.0922}$ \\
\hline 01381200 & $\mathrm{Q}_{\mathrm{m} 01381200}=0.1466 \mathrm{Q}_{\mathrm{m} 01380500}+\mathrm{Q}_{\mathrm{m} 01381000}+\mathrm{Q}_{\mathrm{ps} \mathrm{RVRSA}}$ \\
\hline 01381800 & $\mathrm{Q}_{\mathrm{m} 01381800}=$ Smaller of $\mathrm{Q}_{\mathrm{m} 01381800}$ or $2.330 \mathrm{Q}_{\mathrm{m} 01381500}$ \\
\hline 01382000 & $\mathrm{Q}_{\mathrm{m} 01382000}=1.034 \mathrm{Q}_{\mathrm{m} 01381900}$ \\
\hline \multirow[t]{2}{*}{01382800} & 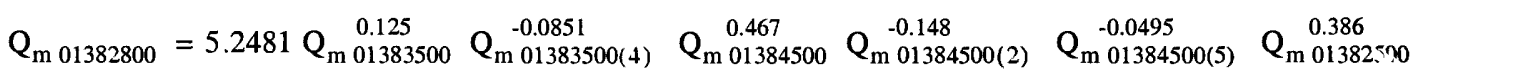 \\
\hline & $\mathrm{Q}_{\mathrm{m} 01382500(3)}^{0.0285} \quad \mathrm{Q}_{\mathrm{m} 01382500(5)}^{0.06}$ \\
\hline 01388910 & $\mathrm{Q}_{\mathrm{m} 01388910}=0.9973\left(1.070 \mathrm{Q}_{\mathrm{m} 01388500}\right)$ \\
\hline 01389005 & $\mathrm{Q}_{\mathrm{m} 01389005}=2.6915 \mathrm{Q}_{\mathrm{m} 01388500}^{0.125} \mathrm{Q}_{\mathrm{m} 01381900}^{0.214} \mathrm{Q}_{\mathrm{m} 01381900(2)}^{0.0317} \mathrm{Q}_{\mathrm{m} 01389500}^{0.529}$ \\
\hline 01389880 & $\mathrm{Q}_{\mathrm{m} 01389880}=0.9963\left(1.245 \mathrm{Q}_{\mathrm{m} .01389500}\right)$ \\
\hline
\end{tabular}


between 15 and 30 percent. The correlation coefficients, which are statistical measurements of accuracy, for streamflow records estimated by using MOVE1 at five stations in the study area ranged from 0.96 to 0.99 . MOVE1 estimates are based on base-flow correlations made by using only about 10 to 15 discharge measurements. MOVE1 estimates generally are accurate for base-flow conditions, but can be in error by as much as 50 to 100 percent during runoff conditions. Error associated with drainage-area ratio estimates may exceed 25 percent. The drainage-area ratio method was found to be more accurate than MOVE1 for estimating flow under medium- and high-flow conditions (R.D. Schopp, U.S. Geological Survey, oral commun., 1999).

\section{Withdrawals of Ground Water and Surface Water}

Withdrawal data are collected differently in New Jersey than in New York. Withdrawal data for New Jersey include metered withdrawals for all categories of use (public supply, commercial, industrial, irrigation, mining, and thermoelectric power), reported to NJDEP as monthly values. Withdrawal data for New York were obtained from various sources and include only public-supply withdrawals. Daily and monthly withdrawal data were obtained directly from the high-volume public suppliers in New York State. Although data are reported as monthly values, the metering methods used to measure withdrawals in New York are unknown.

Total withdrawals of freshwater in the Passaic and Hackensack Basins in 1995 were estimated to be $572 \mathrm{Mgal} / \mathrm{d}\left(885 \mathrm{ft}^{3} / \mathrm{s}\right)--124 \mathrm{Mgal} / \mathrm{d}$ $\left(192 \mathrm{ft}^{3} / \mathrm{s}\right)$ of ground water and $448 \mathrm{Mgal} / \mathrm{d}(693$ $\mathrm{ft}^{3} / \mathrm{s}$ ) of surface water. Estimated withdrawals of saline surface water totaled $440 \mathrm{Mgal} / \mathrm{d}\left(681 \mathrm{ft}^{3} / \mathrm{s}\right)$, although these withdrawals were from sources below the most downstream gages used in this study. Instream use for hydroelectric power totaled $300 \mathrm{Mgal} / \mathrm{d}\left(464 \mathrm{ft}^{3} / \mathrm{s}\right)$. Withdrawals for self-supplied industrial, domestic, mining, commercial, and irrigation uses totaled $25 \mathrm{Mgal} / \mathrm{d}\left(39 \mathrm{ft}^{3} / \mathrm{s}\right), 14$ $\mathrm{Mgal} / \mathrm{d}\left(22 \mathrm{ft}^{3} / \mathrm{s}\right), 8 \mathrm{Mgal} / \mathrm{d}\left(12 \mathrm{ft}^{3} / \mathrm{s}\right), 4 \mathrm{Mgal} / \mathrm{d}(6$ $\left.\mathrm{ft}^{3} / \mathrm{s}\right)$, and $3 \mathrm{Mgal} / \mathrm{d}\left(5 \mathrm{ft}^{3} / \mathrm{s}\right)$, respectively. Withdrawals of ground water and surface water for pub- lic supply totaled $518 \mathrm{Mgal} / \mathrm{d}\left(801 \mathrm{ft}^{3} / \mathrm{s}\right)$. Deliveries of public supplies for domestic, commercial, industrial, and thermoelectric-powe- use were estimated to be $199 \mathrm{Mgal} / \mathrm{d}\left(308 \mathrm{ft}^{3} / \mathrm{s}\right), 65$ $\mathrm{Mgal} / \mathrm{d}\left(101 \mathrm{ft}^{3} / \mathrm{s}\right), 44 \mathrm{Mgal} / \mathrm{d}\left(68 \mathrm{ft}^{3} / \mathrm{s}\right)$, and 1 $\mathrm{Mgal} / \mathrm{d}\left(1.5 \mathrm{ft}^{3} / \mathrm{s}\right)$, respectively. Public use (municipal services and fire protection) and losses (lackwashing filters and pumping equipment, waterconveyance leaks, inaccurate domestic meters, unauthorized use of fire hydrants, and illegal water connections) were estimated to be $110 \mathrm{Mgal} / \mathrm{d}$ (170 $\mathrm{ft}^{3} / \mathrm{s}$ ) (Solley and others, 1998).

\section{Data Sources and Compilation}

In New Jersey, water users report data on monthly withdrawals to NJDEP on either an annual or a quarterly basis. These data are entered in the NJDEP Bureau of Water Allocation (BWA) data base and transferred electronically to the USGS. Data on monthly withdrawals in New York State were collected from various sources, including the USGS, New York District, office in Troy, N.Y.; USEPA's Safe Drinking Water Inventory Sy:tem (SDWIS); Orange County Health Departmert; Suffern Village Water Department; and United Water New York. Monthly withdrawals of surface water for the Village of Nyack were obtained from Bauersfeld and others $(1994,1995)$ and Reed and others $(1996,1997)$. Data on daily withdrawals in both states were obtained directly from high-volume public suppliers and additional daily values for New Jersey withdrawals were obtained f"om the NJDEP Bureau of Safe Drinking Water (BSDW) data base.

The collection of withdrawal data in New Jersey is authorized by the 1981 Water Supply Management Act, and NJDEP monitors witl trawals of ground water and surface water in the State (Saarela, 1992, p. 6). Water users with pumping equipment capable of producing $70 \mathrm{gal} / \mathrm{min}(0.16$ $\mathrm{ft}^{3} / \mathrm{s}$ ) must obtain permission from NJDEP in the form of a permit, registration, or certificatior (Principi, 1991). During a 24-hour period, the amount of water withdrawn by pumping equipment producing $70 \mathrm{gal} / \mathrm{min}$ is about $100,000 \mathrm{gal}$. Water-allocation permits are issued for high-volume $(100,00 \mathrm{Cgal} / \mathrm{d}$ (about $0.15 \mathrm{ft}^{3} / \mathrm{s}$ ) or greater) water withdrawals. Permit holders must submit monthly withdrawal 
data and must recalibrate in-line flowmeters during their permitting period. Well registrants, or lowvolume (less than 100, $000 \mathrm{gal} / \mathrm{d}$ ) water users, must submit reports of monthly metered withdrawals. Agricultural/horticultural certification water users must submit monthly withdrawal data. Because agricultural/horticultural withdrawals are rarely metered, withdrawals commonly are estimated by multiplying the number of hours of use by the pump capacity (Nawyn, 1998).

NJDEP staff entered site-specific monthly withdrawal data for New Jersey into a computerized data base. The NJDEP provided these data as computer files to the USGS as part of the Cooperative Water-Use Program. USGS staff compared and verified site and withdrawal data in the USGS and NJDEP data bases before the data were entered into the USGS Site Specific Water-Use Data System (SWUDS) data base. Unmatched or missing site and withdrawal data were compared with NJDEP paper files; corrected information was entered into the SWUDS data base.

Water use in New York State is monitored less closely than it is in New Jersey. The New York State Department of Environmental Conservation (NYSDEC) is the primary State agency responsible for water-resources management. NYSDEC administers the Water-Supply Permit Program, which requires a permit for public-supply withdrawals. The collection of data on public-supply withdrawals is the responsibility of the New York State Department of Health through county offices or county health departments. Because water suppliers in New York are not required to report withdrawal information, some withdrawals may have been omitted from the calculation of reconstructed streamflow in the State. Self-supplied withdrawals (other than for public supply) in Orange and Rockland Counties in New York State are not monitored by any State agency (Snavely and others, 1990) and were not included in this study.

The latitude and longitude of each withdrawal site was plotted by using a GIS to identify the locations of these sites within the study area. Data on withdrawal sites initially were grouped by watershed (for example, Rockaway River Basin) and then by subwatershed above the nearest USGS gaging station (for example, station 01380500 , Rockaway River above reservoir at Boonton, N.J.). Site data were matched with the New Jersey waterallocation number and New Jersey well-permit or surface-water identifier. Matched data were reviewed for consistency, corrected, and entered in the spreadsheet. Withdrawal values that were reported as "combined" or aggregated by well fields were disaggregated if the values included both ground-water and surface-water withdr'wals or if the sites included in the aggregated value were in different subwatersheds. Site-specific and disaggregated withdrawal values were stored in SWUDS for future retrieval.

\section{Methods Used to Estimate Water Withdrawals}

Values reported as combined withdrawals for multiple wells or for wells and surface-water withdrawals in New Jersey were disaggregated on the basis of the most recent site-specific reported data. If data for a single water-allocation permit w'ere reported only as aggregated values, the monthly values were divided by the number of wells. Wells or surface-water sites that were identified as "standby" or "emergency" were not included in the distribution of the aggregated withdrawal value.

Monthly and daily withdrawal data were collected for all public supplies in New York State except 16 low-volume-withdrawal sites identified in USEPA's SDWIS data base. The daily withdrawals of the Village of Nyack, N.Y., were estimated on the basis of monthly withdrawals reported in Reed and others (1996). To estimate monthly' and daily withdrawals at the remaining 15 sites, the value reported for the population served in the USEPA's SDWIS data base was multiplied ty a daily per capita coefficient. One of two coeff : ients was used: $116 \mathrm{gal} / \mathrm{d}$ per person for public suppliers that deliver to both domestic and non-domestic customers (commercial, industrial, public use) or $85 \mathrm{gal} / \mathrm{d}$ per person for public suppliers that serve only domestic customers (residential subdivisions, mobile home parks) (Nawyn, 1997). The coefficient of $116 \mathrm{gal} / \mathrm{d}$ was estimated on the basis of the monthly withdrawal data (October 1992-Seftember 1996) reported to the Orange County Health Department by seven public suppliers that deliver 
water to residential and other customers in the County. The value for monthly withdrawals reported by each public supplier was divided by the reported retail population in USEPA's SDWIS data base. The result of this calculation was the per capita use for each public supplier. The per capita use of the seven water suppliers was then averaged.

\section{Estimation of Response of Streamflow to Ground-Water Withdrawals}

The hydrologic cycle describes the movement of water above, on, and below the Earth's surface (fig. 7). Precipitation is the source of nearly all freshwater in the hydrologic cycle, but its distribution is highly variable. Precipitation is delivered to surface-water bodies directly, by overland flow, or through subsurface flow routes. Evaporation and transpiration, which return water to the atmosphere, can vary considerably depending on environmental conditions. The movement of water in the atmosphere and on land surface is easier to visualize than the movement of ground water. Surface water typically is hydraulically connected to ground water; however, the interactions are difficult to measure or observe. Many natural processes and human activities affect the interactions of ground water and surface water (Winter and others, 1998).

The source of water to the water table is infiltration of precipitation through the unsaturated zone. The configuration of the water table varies seasonally and from year to year because groundwater recharge is related to wide variations in the quantity, distribution, and timing of precipitation. Ground water in the saturated zone moves along flow paths of varying lengths from areas of recharge to areas of discharge. Flow paths start at the water table, continue through the ground-water system, and end at streams or pumped wells (fig. 8). Flow paths in the uppermost part of an unconfined aquifer can be tens to hundreds of feet in length and have travel times of days to a few years. The longest and deepest flow paths, such as those in the lowermost part of an unconfined aquifer or in a confined aquifer, may be hundreds of feet to miles in length and have travel times that are greater than a decade (Winter and others, 1998).
Streams can interact with ground wate- in several ways. Streams gain water from inflow of ground water through the streambed, lose wa ter to ground water by outflow through the streamted, or gain water in some reaches and lose water in others. For ground water to discharge into the st "eam channel, the altitude of the water table near the stream must be higher than the altitude of the stream surface. Conversely, for surface water to recharge the ground-water system, the altitude of the water table must be lower than the altitucle of the stream surface. Withdrawals from shallow aquifers that are directly connected to surfacewater bodies can have a substantial effect on the movement of water between the two water bodies. The effects of withdrawals from a single well or group of wells on the hydrologic system are local in scale. The effects of many wells withdrawing water from an aquifer over large areas, however, may be regional in scale (Winter and others, 1998).

Ground-water withdrawals can affect streams by reducing base flow (the ground-w'ater contribution to streamflow) or by direct deplation of streamflow. Hill and others (1992) shower that pumping can reduce streamflow and increase. recharge to a valley-fill aquifer by inducing water to flow from the stream to the aquifer. Streamflow losses measured during several seepage runs along the Ramapo River in Oakland Borough at the Soons well field were found to exceed local withdrawals. The effects of withdrawals from a well on streamflow are unique, can vary greatly, and depend on many factors, including well-construction characteristics, the presence and thickne's of confining units in the aquifer, the location of the well within the flow system, the hydrologic and geologic characteristics of the surrounding aquifer material, and the characteristics of the streambed. Detailed simulations of ground-water flow ir the study area would be needed to quantify these. effects for the wells used in this study.

In the study area, ground water typical':' discharges to the streams and lakes that are hydraulically connected to the aquifers. In the upper reaches of the Passaic River Basin, the high-yielding wells are screened in the glacial-deposit aquifers near the streams in the valleys. The lowyielding wells are open to less permeable fractured 


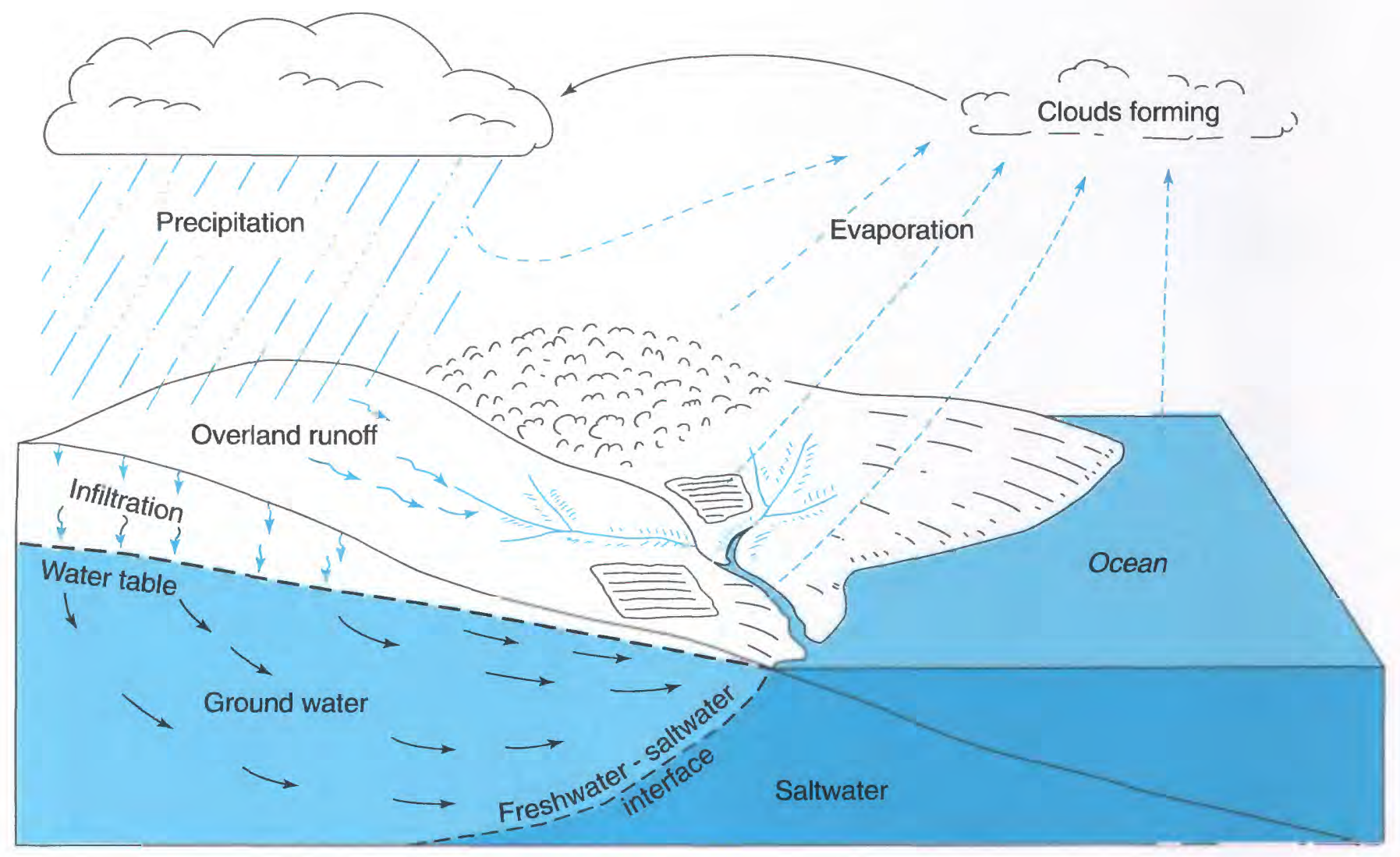

Figure 7. Diagram of the hydrologic cycle. (Modified from Heath, 1983)

bedrock aquifers (Precambrian crystalline rock) in the hills or mountain ridges adjacent to the valleys.

Most of the water withdrawn from wells in the study area comes from Wisconsin and pre-Wisconsin glacial-deposit aquifers. In the Rockaway River Basin, for example, about 97 percent of ground-water withdrawals comes from glacial aquifers that are composed of stratified drift, terminal moraine, or undifferentiated glacial sediments. In contrast, only about 3 percent of ground-water withdrawals comes from wells open to bedrock aquifers, including units composed of Precambrian granite or gneiss and undifferentiated units, or from limestone and dolomite aquifers of the Kittatinny Supergroup. In the Ramapo River Basin, between stations 01388000 (Ramapo River at Pompton Lakes, N.J.) and 01387500 (Ramapo River near Mahwah, N.J.), 89 percent of ground-water with- drawals comes from wells open to aquifers composed of stratified drift. About 11 percent of withdrawals within this subwatershed comes from wells open to bedrock aquifers, predominantly units of the Passaic Formation of the Brunswick Group and Triassic basalt. In the lower reaches of the Passaic and Hackensack River Basins in the Piedmont Physiographic Province, most groundwater withdrawals are from wells open to aquifers of the Brunswick Group, primarily the Passaic Formation.

Topography can prevent ground-water flow between basins. Hoffman and Quinlan (1994) note that ground water under prepumping conditions exited the central Passaic River Basin in one of three ways: upward flow to the surface followed by evapotranspiration, discharge to the Passaic River, or underground flow through the Short Hills Gap. 

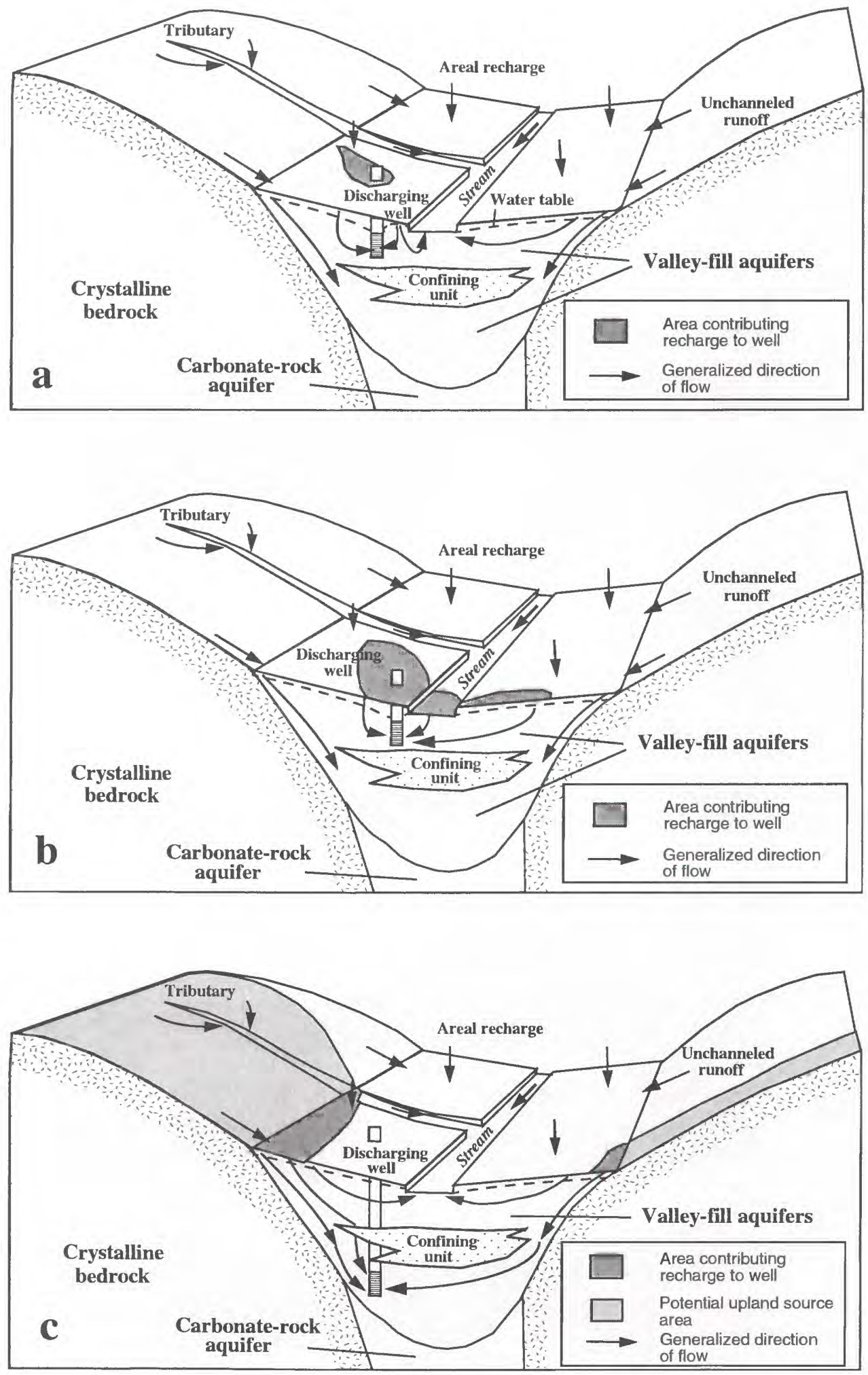

Figure 8. Sources of water to wells: (a) area contributing recharge to a shallow well; (b) area contributing recharge to a shallow well where pumping induces infiltration of surface water; (c) areas contributing recharge to a deep well and potential upland source areas of runoff. (From Nicholson and Watt, 1998) 
Flow through the Short Hills Gap is small, however, because the hydraulic conductivity of the unconsolidated sediment is low.

The response of base flow to ground-water withdrawals from wells within subwatersheds was applied to observed streamflow in a 1:1 ratio--that is, the entire volume of ground water withdrawn was added to the observed-streamflow value. Adding the entire withdrawal to the observed streamflow--that is, making the largest possible correction--is the most conservative approach to calculating the reconstructed streamflow.

Over time, the volume of stream depletion caused by withdrawals from a well approaches the volume withdrawn from that well (Jenkins, 1968). The depletion of a stream continues after pumping stops and the effects of intermittent pumping are approximately the same as those of steady, continuous pumping of the same volume (Jenkins, 1968).

Ground-water withdrawals are largest during summer months and smallest during winter months. If a 6-month delay is assumed to be the longest lag time for changes in the rate of withdrawals to affect base flow, then the effects of the largest withdrawals (during summer) are observed when any reduction in base flow is least critical-during winter, when streamflow is greatest. Conversely, the effects of withdrawals during winter months would be observed during summer lowflow periods.

Reconstructed-streamflow records for four streamflow-gaging stations in the Ramapo River Basin were calculated by using different assumptions regarding the effect of ground-water withdrawals on base flow. Records from these four stations were adjusted for ground-water withdrawals by (1) applying withdrawals in a 1:1 ratio with no time delay, (2) applying withdrawals with a delay of 3 months, (3) applying withdrawals with a delay of 6 months, and (4) assuming no effect from ground-water withdrawals. For example, to apply a 3 -month delay for ground-water withdrawals to reconstructed-streamflow records, ground-water withdrawals in July 1995 were added to the October 1995 observed-streamflow value. To calculate a 6-month delay, July 1995 withdrawals were added to the January 1996 streamflow value.

Differences and percent differences between reconstructed-streamflow values with no delay in ground-water withdrawals and reconstructedstreamflow values with a 3-month delay in groundwater withdrawals were greatest during the summer and fall months of 1993 and 1995, when observed streamflow was lowest (fig. 9). During these periods, reconstructed-streamflow values with 3-month delays were greater than reconstructed-streamflow values with no delay. Maximum positive differences during October 1992 through September 1996 were $12.9 \mathrm{ft}^{3} / \mathrm{s}$ (20.4 percent) for September 1993 at station 01388000 (Ramapo River at Pompton Lakes, N.J.) and 32.9 percent $\left(8.7 \mathrm{ft}^{3} / \mathrm{s}\right)$ for September 1995 at station 01387500 (Ramapo River near Mahwah, N.J.). In general, reconstructed-streamflow values with 3month delays were less than reconstructed-streamflow values with no delay during winter and spring months. Maximum negative differences during October 1992 through September 1996 were $14.1 \mathrm{ft}^{3} / \mathrm{s}$ (-2.8 percent) for January 1993 at station 01388000 (Ramapo River at Pompton Lakes, N.J.) and -21.3 percent $\left(0.8 \mathrm{ft}^{3} / \mathrm{s}\right)$ for August 1995 at station 01387450 (Mahwah River near Suffern, N.Y.). Similar differences were found when ground-water withdrawals were delayed by 6 months (fig. 10).

Differences between reconstructed-streamflow values with and without delays in groundwater withdrawals at the two most upstream stations in the Ramapo River Basin, 01387400 (Ramapo River at Ramapo, N.Y.) and 01387450 (Mahwah River near Suffern, N.Y.), were minimal, primarily because there are few wells and the volume of ground-water withdrawals is small. Differences at the two most downstream stations were greater, but still small in comparison to the effect of removing ground water altogether. By removing the effect of ground-water withdrawals on base flow entirely, differences were apparent during the summer months, when streamflow was lowest (fig. 11). This alternative is unrealistic because groundwater withdrawals do affect streamflow, and is presented here only to show the maximum effect of withdrawals on streamflow. At station 01388000 (Ramapo River at Pompton Lakes, N.J.), the maxi- 

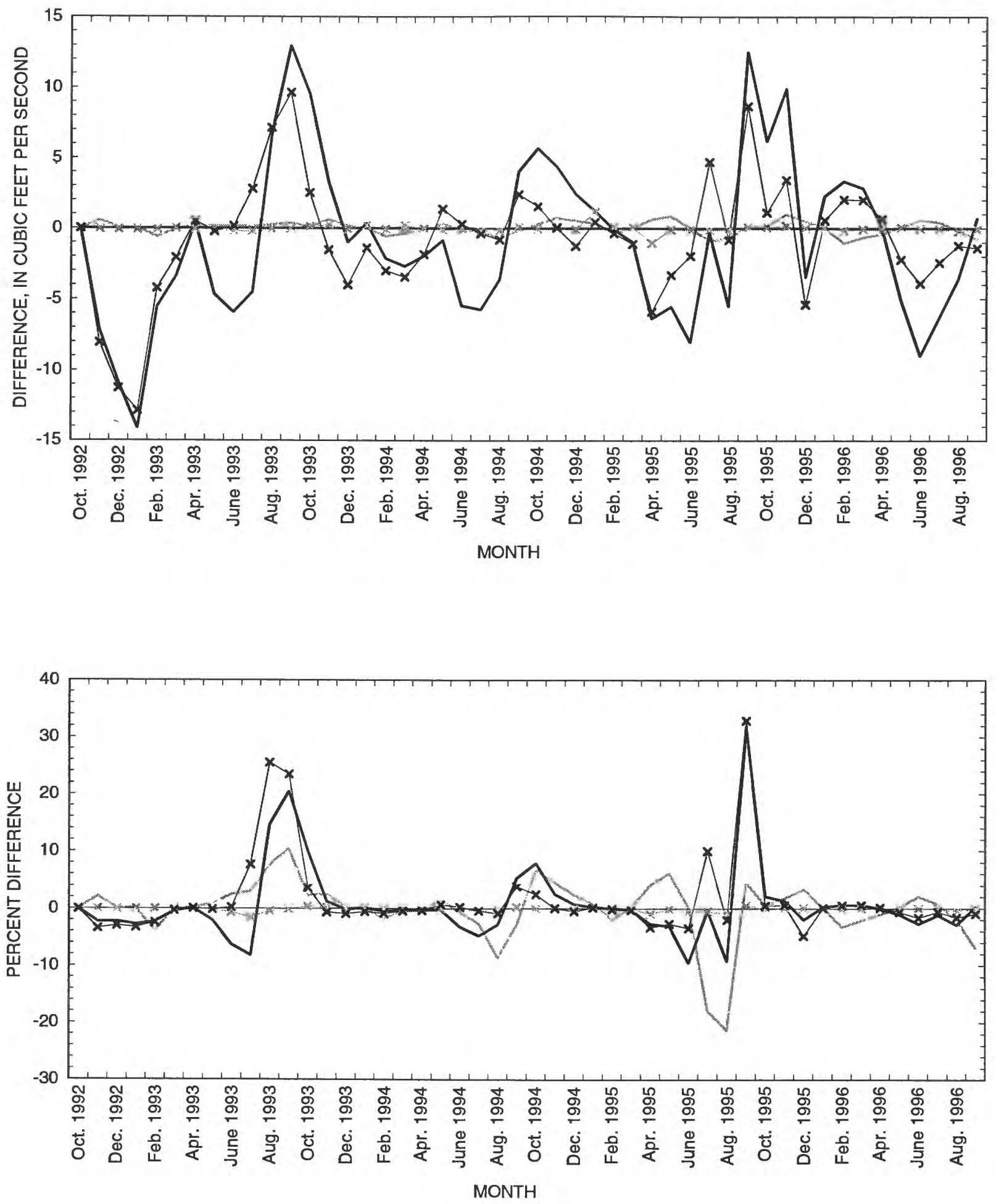

\section{EXPLANATION}

01387400 Ramapo River at Ramapo, N.Y.

01387450 Mahwah River near Suffern, N.Y.

× 01387500 Ramapo River near Mahwah, N.J.

01388000 Ramapo River at Pompton Lakes, N.J.

Figure 9. Difference between reconstructed streamflow with no delay and reconstructed streamflow with ground-water withdrawals delayed 3 months for streamflow-gaging stations in the Ramapo River Basin, New Jersey and New York. 

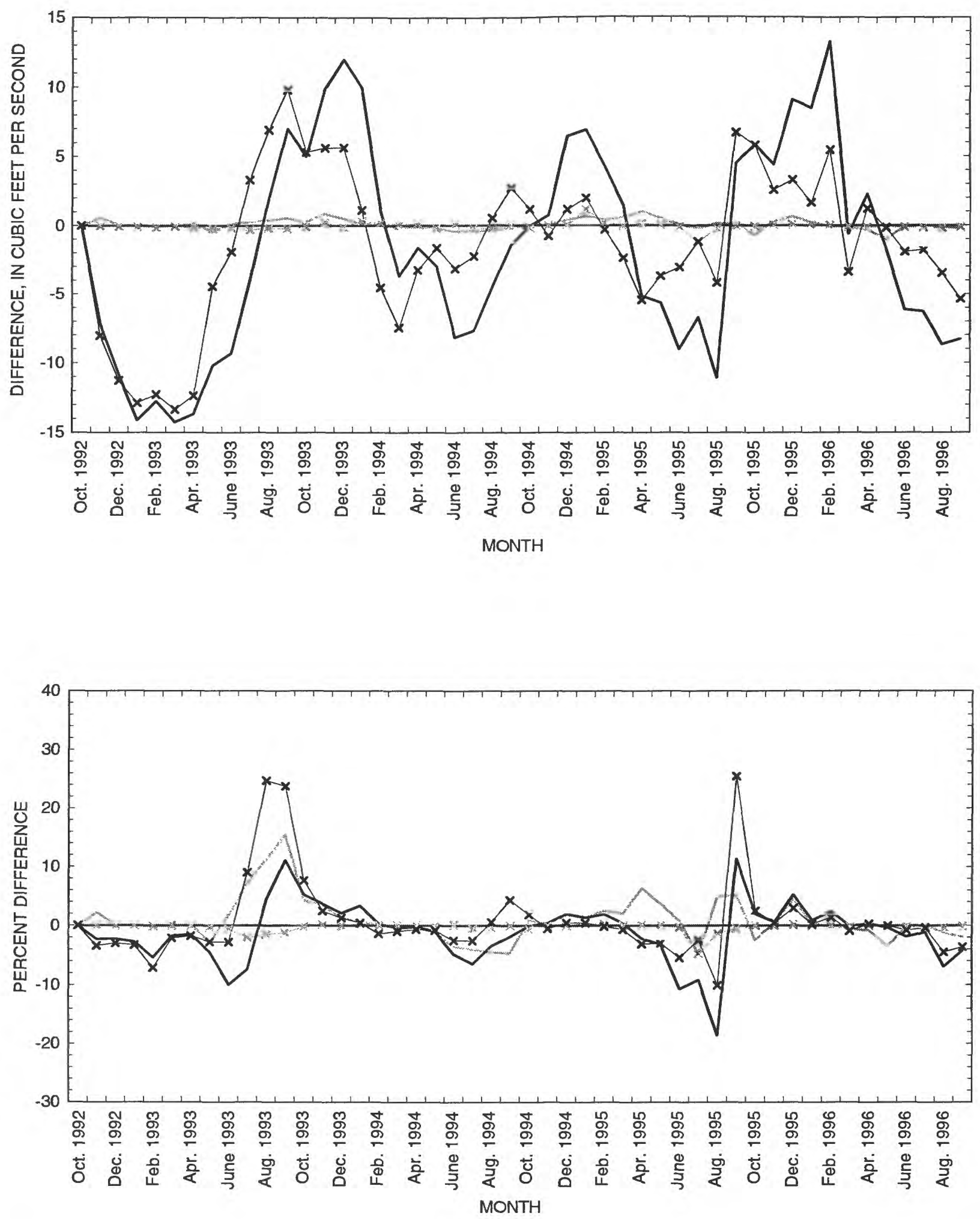

EXPLANATION

* 01387400 Ramapo River at Ramapo, N.Y.

01387450 Mahwah River near Suffern, N.Y.

× 01387500 Ramapo River near Mahwah, N.J.

01388000 Ramapo River at Pompton Lakes, N.J.

Figure 10. Difference between reconstructed streamflow with no delay and reconstructed streamflow with ground-water withdrawals delayed 6 months for streamflow-gaging stations in the Ramapo River Basin, New Jersey and New York. 


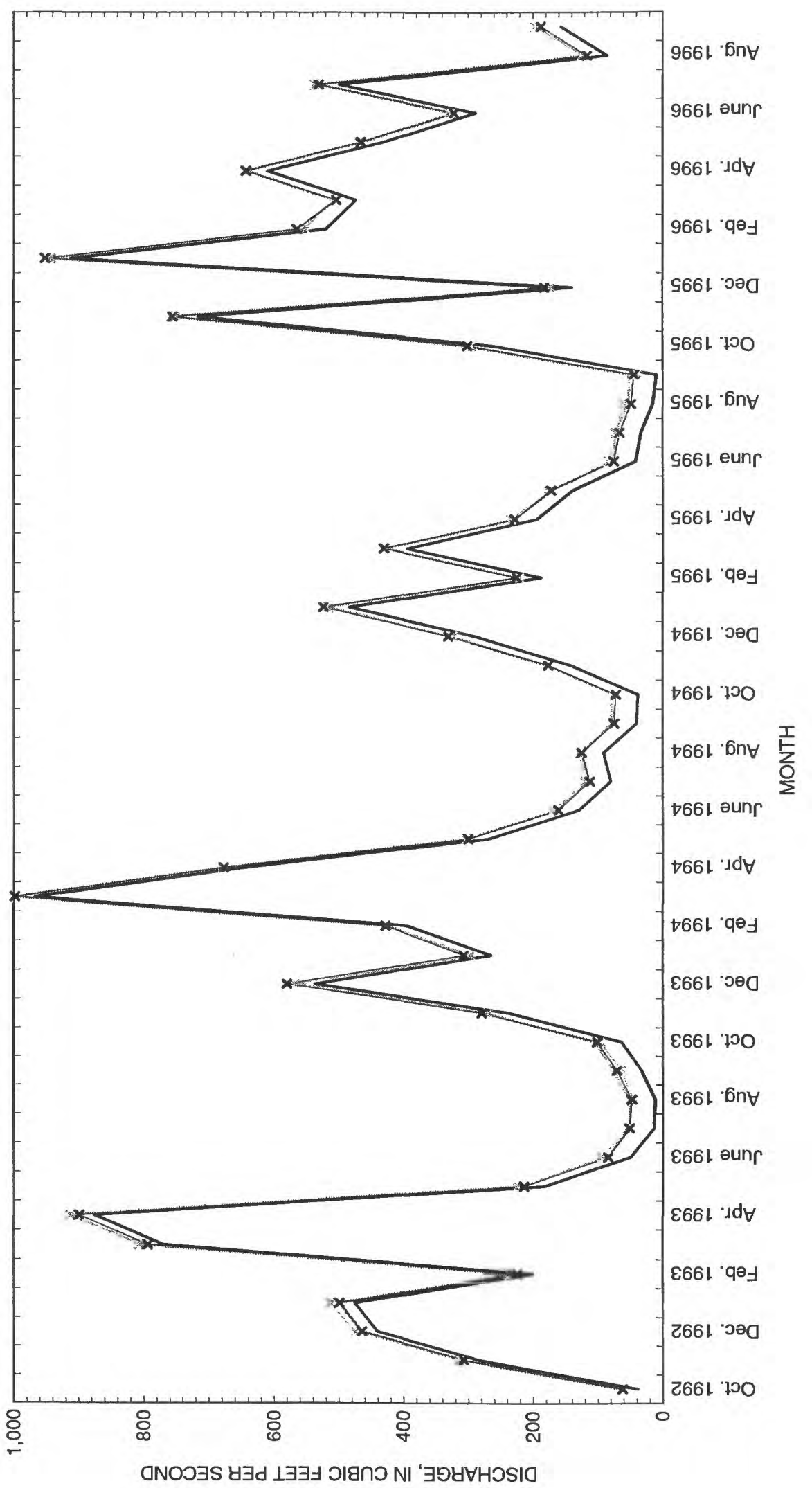

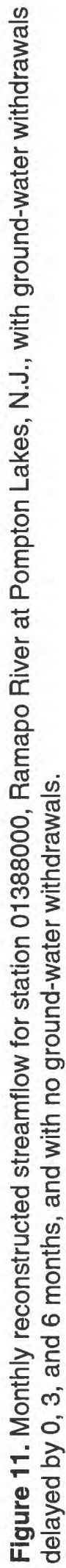

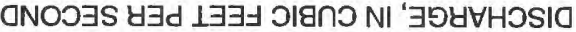


mum difference between reconstructed streamflow with ground-water withdrawals applied $\left(59.5 \mathrm{ft}^{3} / \mathrm{s}\right)$ and reconstructed streamflow with ground-water withdrawals removed $\left(15.0 \mathrm{ft}^{3} / \mathrm{s}\right)$ was -76 percent in August 1995. The average difference during the 4-year study period was $35 \mathrm{ft}^{3} / \mathrm{s}$, or 23 percent.

Previous investigations of ground-water/surface-water interactions in New Jersey have indicated that a 1:1 ratio of ground-water withdrawals to base-flow reduction is a reasonable estimate for most subwatersheds in the study area. LewisBrown and Jacobsen (1995) used average-annual withdrawals and average-annual base flow to estimate prepumping base flow in a ground-waterflow model of the west-central region of New Jersey. By using a flow model of the upper Rockaway River Basin, Gordon (1993) demonstrated that water in the deeper, confined aquifers discharges through wells or eventually flows upward and discharges into the Rockaway River and that only a small amount of water can enter or exit the aquifer through the underlying bedrock. She noted that because the confining units are discontinuous and leaky in many places, differences in water levels between confined and unconfined aquifers is small. Gordon also assumed that the sum of measured base flow and ground-water withdrawals (total ground-water discharge) equaled the calculated ground-water recharge.

An object-oriented streamflow model that can be used to test assumptions about the effects of ground-water withdrawals on base flow or direct streamflow depletion is being developed by NJDEP. The model allows the user to adjust the effects of ground-water withdrawals on base flow in two ways: first, by using a coefficient to allow the user to vary the effects of ground-water withdrawals on streamflow from 0 to 1 , and second, by using a time-delay factor incorporated into the model to delay the effects of ground-water withdrawals between 0 and 6 months. Effects of withdrawals can then be assessed by comparing the results of model simulations that incorporate alternative assumptions about the relation between ground-water withdrawals and streamflow.

\section{Reliability of Data}

Withdrawal data collected by the NJDEP are highly reliable because the withdrawals are metered and many of the in-line flowmeters are recalibrated periodically. In addition, annual withdrawal data were reviewed by the USGS for consistency with previously reported information. Withdrawal data were aggregated by aquifer, county, HUC, and category of use; inconsistencies in aggregated values were resolved by contanting the NJDEP or the water user.

Withdrawal data for sites in New York State include estimated data and therefore are the least reliable withdrawal data in this report. Although data on high-volume public suppliers were obtained directly from the water user and are considered reliable, data on low-volume public suppliers were estimated on the basis of reported values for similar-sized public suppliers in the area. Withdrawals may have been applied incorrectly in the calculation of reconstructed streamflow if the permits did not clearly state use or disposition c $f$ a withdrawal or discharge. For example, if a w'ell discharged directly to a stream, but this was not indicated in the permit, the withdrawal would have been added to reconstructed streamflow when it should have been subtracted. Data on public suppliers who serve only residential customers were estimated on the basis of analysis of domesti? deliveries of water-supply systems in New Jersey (Nawyn, 1997).

\section{Point-Source Discharges}

Point-source discharges consist of water discharged as effluent (waste) from homes, businesses, and industries after the water has been processed to remove solids or other undesirable constituents. Wastewater-treatment facilities include municipal systems, privately owned residential systems serving smaller communities (residential subdivisions and mobile-home parks), and commercial and industrial facilities. The effl:ient generated from commercial businesses and industrial plants may be treated at a municipal system or onsite at a privately owned wastewater-treatment facility. About 75 percent of the population (U.S. Bureau of the Census, 1994) in the study area is 
served by a municipal or privately owned wastewater-treatment facility; about 25 percent of the population uses cesspools or septic tanks for wastewater treatment.

\section{Data Sources and Compilation}

Facilities that discharge water to a surfacewater body (lake, stream, or ocean) must apply for a National Pollutant Discharge Elimination System (NPDES) permit. This Federal program is administered in New Jersey by NJDEP and in New York State by NYSDEC. Each State agency collects data on the quantity and quality of wastewater discharges and transfers this information to USEPA's Permit Compliance System (PCS) data base. For New Jersey discharge sites, point-source discharge data on file at the NJDEP were obtained as a check on data retrieved from the PCS. In theory, the two data bases should be identical with respect to location and discharge data because the data in one are obtained from the other. In fact, however, some discrepancies were found. These discrepancies were identified and resolved to create a list of sites with NPDES permits in the study area. Wastewater-treatment facility outfall pipes in the subwatersheds of the study area were plotted by latitude and longitude. If the location of an outfall pipe was unknown, the location of the wastewater-treatment facility was plotted. NPDES discharge locations were matched with data on monthly wastewater discharges. Unmatched or missing monthly discharge data were identified and corrected information was obtained from USEPA. Data on daily wastewater discharges from most high-volume facilities (greater than $0.25 \mathrm{Mgal} / \mathrm{d}\left(0.4 \mathrm{ft}^{3} / \mathrm{s}\right)$ ) were obtained from the treatment facility.

\section{Methods Used to Estimate Wastewater Discharges}

Wastewater-discharge data were reported monthly for most sites in the study area. For some sites, however, only quarterly, semi-annual, or annual values were reported. These values were reported as an average monthly discharge during the reporting period. Monthly data were estimated for 29 outflow pipes for which reports were made. The average monthly discharge was entered in the spreadsheet for each monthly period preceding the reporting time. Daily values for low-volume pointsource discharge facilities were estimated on the basis of monthly values.

Missing monthly values for several muricipal treatment facilities were estimated by using a least-squares regression between the facility's reported monthly discharges and streamflow $c^{t}$ a nearby streamflow station. The correlation was used to develop a best-fit line for periods when discharge records were available. Missing values were then estimated by using the equation of the lire. Sites and periods for which this method was used are Livingston Township Sewage Treatment F'ant (NJ0024511), February, April, May, and June 1994; Butterworth Sewage Treatment Plant (NJ0024911), December 1992; and Hanover Sewerage Authority (NJ0024902), September 1993 through April 1995 and November 1995 through September 1996.

\section{Estimation of Infiltration and Inflow}

The age and integrity of the wastewater-collection and -discharge systems in the study area vary widely, but all municipal wastewater-treatment systems receive some infiltration and inflow. Infiltration is ground water that enters a sewer system through broken pipes, pipe joints, and illegal connections of foundation drains. Inflow is surface runoff that enters a sewer system through manhole covers, exposed broken pipes and pipe joints, cross-connections between storm sewers and sanitary sewers, and illegal connections of roof leaders, cellar drains, yard drains, and catch basins (U.S. Environmental Protection Agency, 1985).

Infiltration and inflow can substantially increase the volume of point-source discharges, such as effluent from sewage-treatment facilities, released into streams. Water can enter sewer pipes during storms and cause short-term increases in the volume discharged by treatment facilities. The altitude of the water table relative to the altitude of the collection system is an important factor in determining whether a wastewater-treatment system receives a large volume of infiltration. In areas where the water table fluctuates greatly, or in lowlying areas where the unsaturated zone is thin or absent, collection systems can be submerged for 
extended periods. If broken pipes or leaky joints are present, large volumes of ground water can enter the treatment system.

Results of previous investigations have indicated that point-source discharges from municipal treatment facilities are highly correlated with streamflow (T. H. Barringer, U.S. Geological Survey, written comun., 1998). Discharge data from 17 high-volume sewage-treatment facilities in the study area were analyzed to verify this correlation. Discharge was found to be correlated with streamflow at gaging stations above and below the point of discharge. Most of the discharges from treatment facilities were strongly correlated with streamflow.

To adjust for these effects, infiltration and inflow were treated as a nonpermitted or unaccounted-for ground- and surface-water withdrawal in the reconstructed-streamflow equation. Monthly point-source discharges from municipal treatment facilities with average monthly discharges greater than $2 \mathrm{Mgal} / \mathrm{d}\left(3 \mathrm{ft}^{3} / \mathrm{s}\right)$ were plotted as a function of time to determine discharge patterns and to estimate the volume of infiltration and inflow. These plots were used to determine "a base effluent value"--the lowest monthly discharge observed during the 4-year study period, during an extended dry period in which infiltration and inflow were considered to be minimal. For all other months, any discharge greater than this base value was considered to be the result of infiltration and inflow.

Service areas for treatment facilities were determined by using information from two sources: maps that were developed in the 1960's and 1970's that show actual areas served by the facilities (New Jersey Department of Environmental Protection, 1974), and tables that list current treatment facilities by municipality served (Zripko and Hasan, 1994). Mean daily discharge values from the two periods were compared to determine the percentage of expansion of the treatment systems, if any, that occurred over time. The percentage of the area served within each municipality was then estimated. A GIS was used to determine the area of each municipality served by a treatment facility and each subwatershed in the study area. The service area was then calculated for each municipality and totaled by subwatershed. Values of infiltration and inflow were distributed over the service area as a percentage of the area that falls within each subwatershed. For example, if a treatment facilit"' served areas in two subwatersheds, the percentage of the infiltration and inflow associated with each subwatershed was calculated on the basis of the area of that subwatershed served by the treatment facility and was applied to the reconstructed flow at the station for that subwatershed. If the ent're service area of a treatment facility fell within one subwatershed, all of the infiltration and inflow was applied to the reconstructed streamflow at the station in that subwatershed.

Daily reconstructed-streamflow values were not corrected for infiltration and inflow because precipitation during the 8 months preceding the period for which daily values were reconstructed (September 1, 1994 through April 31, 1995) was below average. During this 8-month period, precipitation was 8 in. less than the average (1961-nn) precipitation. From May 1, 1995, to September 31, 1995, precipitation was about 5 in. below average (National Climatic Data Center, 1993-97).

Although about 5 in. of precipitation was reported for October 1995, the effect of this precipitation on infiltration was assumed to be minimal because of the antecedent drought conditions. Plots of daily discharge as a function of time and analysis by least-squares regression showed little correlation between point-source discharge and streamflow. Therefore, infiltration and inflow are considered to have been minimal during this time period.

Exfiltration is effluent that leaks from vastewater-collection systems through broken pipes and pipe joints. In some systems, exfiltration may reduce the volume of wastewater that is treated at treatment facilities. Information that documents the occurrence and quantity of exfiltration from collection systems is limited, and no reliable methots to estimate the quantity of exfiltration are available. During extended dry periods, when the altitude of the water table is low and the pipes of collect' $n$ systems are above the water table, exfiltratior may occur. Exfiltration from most collection systems, however, is believed to be minimal. Because exfiltration from collection systems would increase the altitude of water table in the vicinity of the leakage, 
the ground-water contribution to streams would likely show a corresponding increase. Because the effect of exfiltration on streamflow probably is small in comparison to the effects of other factors, reconstructed-streamflow values were not adjusted for exfiltration.

\section{Reliability of Data}

Site and discharge data from two data sources--USEPA and NJDEP data bases--were compared. Reported values were checked for consistency and corrected as necessary. Missing data were estimated on the basis of previously reported data and least-squares regression analysis with streamflow. Point-source discharge patterns were checked for consistency over time. Estimates of infiltration and inflow may be inaccurate, but values are small compared to streamflow and, therefore, do not introduce large errors in reconstructedstreamflow records. For all subwatersheds that include service areas for wastewater-treatment facilities, infiltration and inflow averaged about 0.6 percent of reconstructed streamflow. In the Rockaway River Basin, for example, infiltration and inflow averaged about 0.5 percent of reconstructed streamflow. The maximum value was about 2.5 percent $\left(1.0 \mathrm{ft}^{3} / \mathrm{s}\right.$ of the $39.9-\mathrm{ft}^{3} / \mathrm{s}$ reconstructedstreamflow value) at station 01380500 (Rockaway River above reservoir at Boonton, N.J.) during the low-flow period of August 1995.

\section{Changes in Reservoir Storage}

Change-in-storage data were compiled for 15 large reservoirs in the Passaic and Hackensack River Basins (table 3). These reservoirs include all major water-supply reservoirs in the Newark, North Jersey District Water Supply Commission, Jersey City, and United Water reservoir systems, as well as Point View Reservoir and Greenwood Lake. Several other small water-supply and (or) flood-control reservoirs are present in the study area, but they generally exhibit only minor changes in storage that have little effect on streamflow. Withdrawals from all of these reservoirs are included in the calculation of reconstructed streamflow. Reservoir operators record elevations of water levels daily at most reservoirs. Elevations at Greenwood Lake and Wanaque Reservoir are recorded by the USGS and stored in the ADAPS data base. Month-end elevations were conve"ted to reservoir-storage values by using tables developed on the basis of reservoir geometry. Change-in-storage values were calculated by subtracting the previous month-end storage value from the current month-end storage value. Change-in-storage values for months when reservoir storage declined are negative and were subtracted from observed streamflow. For these months, reconstructed streamflow is less than observed streamflow because part of the observed streamflow is dorived from the release of water from the reservoir rather than being the result of natural conditions. $C$ ' angein-storage values for months when reservoir storage increased are positive. Because water was held back to increase storage, observed streamflow was less than it would have been without regulat:on, and reconstructed streamflow is greater than observed streamflow. Daily change-in-storage values were calculated from daily elevation data by using the same method used to calculate monthly values. Change-in-storage values were then entered into the spreadsheet and applied to the observed streamflow.

\section{Records of Reservoir Storage}

Month-end reservoir change-in-storage data for October 1992 through September 1996 for all 15 reservoirs are published annually by the USGS in water-resources data reports (Bauersfeld and others, 1994, 1995; Reed and others, 1996, 1997). These data were entered into the spreadsheet and used to calculate monthly reconstructed streamflow.

Daily reservoir-storage or reservoir-elevation data for May 1, 1995, through October 31, 1995 , for the 15 reservoirs were collected from the operators of the reservoirs. These values were then converted to change-in-storage values (by the same method described above) in cubic feet per second, entered into the daily spreadsheet, and used to calculate daily reconstructed streamflow.

\section{Estimation of Missing Data}

The monthly and daily data sets were complete for all reservoirs for the entire study period 
Table 3. Reservoirs for which change-in-storage values were calculated and associated information

[USGS, U.S. Geological Survey; JC, Jersey City; NJDWSC, North Jersey District Water Supply Commission; PVWC, P-ssaic Valley Water Commission; UWNJ, United Water New Jersey; UWNY, United Water New York]

\begin{tabular}{|c|c|c|c|c|c|c|}
\hline $\begin{array}{c}\text { USGS } \\
\text { station } \\
\text { number }\end{array}$ & Reservoir & $\begin{array}{l}\text { Reservoir } \\
\text { operator } \\
\text { or owner }\end{array}$ & $\begin{array}{l}\text { Total capacity, } \\
\text { in million } \\
\text { gallons }\end{array}$ & $\begin{array}{c}\text { Drainage } \\
\text { area, in } \\
\text { square miles }\end{array}$ & $\begin{array}{l}\text { Spillway } \\
\text { elevation, in } \\
\text { feet above } \\
\text { sea level }\end{array}$ & $\begin{array}{c}\text { Late } \\
\text { comnleted }\end{array}$ \\
\hline $\begin{array}{l}01376700 \\
01376950 \\
01377450 \\
01378480 \\
01379990\end{array}$ & $\begin{array}{l}\text { De Forest Lake } \\
\text { Lake Tappan } \\
\text { Woodcliff Lake } \\
\text { Oradell Reservoir } \\
\text { Splitrock Reservoir }\end{array}$ & $\begin{array}{l}\text { UWNY } \\
\text { UWNJ } \\
\text { UWNJ } \\
\text { UWNJ } \\
\text { UWNJ/JC }\end{array}$ & $\begin{array}{r}5,670 \\
3,853 \\
871 \\
3,507 \\
3,306\end{array}$ & $\begin{array}{c}27.5 \\
49.0 \\
19.4 \\
113 \\
5.50\end{array}$ & $\begin{array}{l}85.00 \\
55.00 \\
95.00 \\
23.16 \\
835\end{array}$ & $\begin{array}{l}1 \subseteq 56 \\
1 \subseteq 56 \\
1 \subseteq 05 \\
1 \subseteq 22 \\
1 \subseteq 48\end{array}$ \\
\hline $\begin{array}{l}01380900 \\
01382100 \\
01382200 \\
01382300 \\
01382380\end{array}$ & $\begin{array}{l}\text { Boonton Reservoir } \\
\text { Canistear Reservoir } \\
\text { Oak Ridge Reservoir } \\
\text { Clinton Reservoir } \\
\text { Charlotteburg Reservoir }\end{array}$ & $\begin{array}{l}\text { UWNJ/JC } \\
\text { Newark } \\
\text { Newark } \\
\text { Newark } \\
\text { Newark }\end{array}$ & $\begin{array}{r}17,620 \\
2,407 \\
3,895 \\
3,518 \\
2,964\end{array}$ & $\begin{array}{l}119 \\
5.60 \\
27.3 \\
10.5 \\
56.2\end{array}$ & $\begin{array}{c}305.25 \\
1,086.0 \\
846.0 \\
992.0 \\
743.00\end{array}$ & $\begin{array}{l}1504 \\
1896 \\
1880 \\
1889 \\
1561\end{array}$ \\
\hline $\begin{array}{l}01382400 \\
01383000 \\
01384002 \\
01386990 \\
01387860\end{array}$ & $\begin{array}{l}\text { Echo Lake } \\
\text { Greenwood Lake } \\
\text { Monksville Reservoir } \\
\text { Wanaque Reservoir } \\
\text { Point View Reservoir }\end{array}$ & $\begin{array}{l}\text { Newark } \\
\text { State of N.J. } \\
\text { NJDWSC } \\
\text { NJDWSC } \\
\text { PVWC }\end{array}$ & $\begin{array}{r}1,630.5 \\
7,140 \\
7,000 \\
29,630 \\
2,800\end{array}$ & $\begin{array}{c}4.35 \\
27.1 \\
40.4 \\
90.4 \\
1.89\end{array}$ & $\begin{array}{l}893.50 \\
618.86 \\
400.0 \\
302.4 \\
386.0\end{array}$ & $\begin{array}{l}1925 \\
1837 \\
1528 \\
1527 \\
15 \$ 4\end{array}$ \\
\hline
\end{tabular}

Total capacity with bascule gates (counter-balanced gates on top of the dam) open. Total capacity with bascule gates closed is 7.989 million gallons, with spillway elevation of 307.25 feet above sea level.

except Greenwood Lake. Change in storage for 3 months (January-March 1994) when the lake was drawn down for dam maintenance was estimated from periodic measurements made during this period and observed streamflow at gaging station 01383500, Wanaque River at Awosting, N.J., located just downstream from Greenwood Lake.

\section{Reliability of Data}

Reservoir-storage data generally are accurate; however, inaccuracies may result from certain situations. For example, the conversion of water level to reservoir storage may be inaccurate as a result of changes in reservoir capacity due to the deposition of sediment over time without a corresponding change in the water-level-storage relation tables. Water levels measured too close to the reservoir outflow or near water-supply intakes may be inaccurate. Wind also may cause inaccurate measurements of water levels. If, for example, the water-level measurement of the Wanaque Reservoir was in error by $0.1 \mathrm{ft}$ when the reservoir was full, the reservoir-storage value would be in error by $80 \mathrm{Mgal}$. Inclusion of this error in the calculation of change in storage for July 1995 would result in a difference of $4 \mathrm{ft}^{3} / \mathrm{s}$, and the resulting recon- structed-streamflow value would be in error by about 13 percent. Additionally, water may be released from lakes or reservoirs to meet minimum passing streamflow requirements. If change-instorage values are not calculated for the reservoir, calculations of reconstructed streamflow may be incorrect. The magnitude and frequency of $\mathrm{t}$ 'se types of errors are unknown.

\section{RECONSTRUCTION OF STREAMFLOW RECORDS}

Observed streamflow is the quantity of water that passed a given point in a stream channel within a given time period and is the result of the interaction between natural conditions and human activities. Natural streamflow is the quantity of water that would have passed the same point without the influence of human activities. Reconstructed streamflow is the quantity of water calculatet through use of a mass-balance equation, based on observed streamflow, that takes into consideration certain known human activities, including surfaceand ground-water withdrawals; discharges tc surface-water bodies; changes in storage in water-supply reservoirs; transfers of water into, out of, or within river basins; and other factors. Because 
it does not account for all human activities, however, reconstructed streamflow is not equivalent to natural streamflow. The reconstruction method does not attempt to include all factors that may affect streamflow--for example, changes in land use, some gains and losses associated with the operation of reservoirs, and the effect of residential wells and septic systems. Many of these factors are not easily quantified and many others may be unknown. Data sets of monthly mean observedstreamflow values for each of the 34 streamflow stations for water years 1993 through 1996 and daily mean observed-streamflow values for May through October 1995 were developed and then adjusted to remove the effects of the known human influences listed above to produce reconstructedstreamflow records.

\section{Description of Methods}

The equation used to reconstruct streamflow values was derived from a general form of a waterbalance equation:

$$
\mathrm{Q}=\mathrm{P}-\left(\mathrm{E}+\Delta \mathrm{S}_{\mathrm{S}}+\Delta \mathrm{S}_{\mathrm{g}}\right)
$$

where $Q$ is runoff, $P$ is precipitation, $E$ is evapotranspiration, $\Delta S_{S}$ is change in storage of the surface-water reservoir, and $\Delta S_{g}$ is change in storage of the ground-water reservoir. In this equation, it is assumed that surface-water and ground-water divides coincide, and that no ground water flows into or out of the study area across divides (Freeze and Cherry, 1979). This equation was modified to permit the use of readily available data for the calculation. To make this modification, several additional assumptions were necessary, and the operating conditions of the reconstructed-streamflow system were defined.

The primary conditions of the reconstructedstreamflow system were that surface-water and ground-water withdrawals are 0 , point-source discharges are 0 , and reservoirs act as unregulated natural lakes. A correction for evaporation losses was not included in the equation because reservoirs were assumed to be natural lakes. It was assumed that evaporation from natural lakes is nearly equal to evaporation from reservoirs, and that leakage from natural lakes is equal to leakage from reser- voirs. By making these assumptions, the only correction needed would be that for the difference between evaporation losses from a full natural lake and losses from a reservoir that is full only part of the time. In summer months, when reservoir levels decline, evaporation losses would be less then those from a natural lake because the surface area is smaller. This difference was considered to be small in comparison to other variables in the equation. If the reservoirs were removed from the reconstructed-flow system, however, a corre tion factor would be needed because evaporation losses from a reservoir or lake can be substantial dıring summer months.

Changes in bank storage due to conversion of reservoirs to natural lakes were assumed to be negligible, direct rainfall on natural lakes was assumed to equal direct rainfall on reservoirs and water use from domestic wells was assumed to equal discharge to septic systems and to havo little or no effect on base flow. Consumptive losses, estimated to be about 8 percent of total use for domestic systems, may affect base flow but, becaus? most of the population in the study area receives their water from public suppliers, the use of private wells and septic systems likely has little effect on base flow. Changes in runoff and recharge due to changes in land use from the natural system to the current system were not considered, but can have a substantial effect on streamflow. Ground-water withdrawals were assumed to reduce base flcw in a 1:1 ratio--that is, 1 gal of water withdrawn from a well reduces base flow by an equal volume. This assumption will be tested in NJDEP's object-oriented model to evaluate the effect of withdre wals on base flow.

Monthly and daily reconstructed streamflow for stream segments was calculated by using the following equations:

$$
\begin{gathered}
\mathrm{Q}_{\mathrm{r}}=\mathrm{Q}_{\mathrm{r}-1}+\Delta \mathrm{Q}_{\mathrm{r}} \text {, and } \\
\Delta \mathrm{Q}_{\mathrm{r}}=\Delta \mathrm{Q}_{\mathrm{m}}+\mathrm{W}_{\mathrm{sW}}-\mathrm{T}_{\mathrm{sW}}+\mathrm{W}_{\mathrm{gw}}-\mathrm{T}_{\mathrm{gw}}+\Delta \mathrm{S}- \\
\mathrm{Q}_{\mathrm{ps}}(1-\mathrm{fp})
\end{gathered}
$$

where $Q_{r}$ is monthly reconstructed streamflcw; $\mathrm{Q}_{\mathrm{r}-1}$ is monthly reconstructed streamflow at an 
adjacent upstream station; $\Delta \mathrm{Q}_{\mathrm{r}}$ is change in monthly reconstructed streamflow between stations; $\Delta Q_{m}$ is change in monthly observed or estimated streamflow between streamflow stations; $\mathrm{W}_{\mathrm{SW}}$ is monthly surface-water withdrawals from within the subwatershed; $T_{S W}$ is surface-water transfers into the subwatershed from another subwatershed; $\mathrm{W}_{\mathrm{gw}}$ is monthly ground-water withdrawals from within the subwatershed; $T_{g w}$ is ground-water transfers into the subwatershed from another subwatershed or transfers within the subwatershed; $\Delta S$ is change in storage in reservoirs within the subwatershed; $\mathrm{Q}_{\mathrm{ps}}$ is monthly surfacewater point-source discharge within the subwatershed; and $\mathrm{fp}$ is the fraction of point-source discharge due to infiltration and inflow. Daily reconstructed flow was calculated by using the same model.

Monthly and daily reconstructed streamflow for each gaging station was calculated in the spreadsheet by using the following equation:

$$
\begin{gathered}
\mathrm{Q}_{\mathrm{r}}=\mathrm{Q}_{\mathrm{m}}+\mathrm{W}_{\mathrm{sw}}-\mathrm{T}_{\mathrm{sw}}+\mathrm{W}_{\mathrm{gw}}-\mathrm{T}_{\mathrm{gw}}+\Delta \mathrm{S}-\mathrm{Q}_{\mathrm{ps}}+ \\
\mathrm{II}+\left(\mathrm{Q}_{\mathrm{r}-1}-\mathrm{Q}_{\mathrm{m}-1}\right),
\end{gathered}
$$

where $Q_{m}$ is observed streamflow; II is infiltration and inflow; and $\left(Q_{r-1}-Q_{m-1}\right)$ is the difference between reconstructed and observed streamflow at adjacent upstream gaging stations.

\section{Reconstructed-Streamflow Records}

In general, water in both the Passaic and Hackensack River Basins is transported, for use for public supply, from the upper reaches of the basins to urban centers in the eastern and southeastern part of the study area near New York City. A net loss of water from these basins is primarily the result of withdrawals from within the study area that are returned to surface-water bodies as pointsource discharges outside the study area, including the lower reaches of the Passaic and Hackensack Rivers below the most downstream gaging stations in the study area, Newark Bay, and New York Bay. Reconstructed streamflow therefore is greater than the observed streamflow at most stations. The difference between reconstructed and observed streamflow is an indication of the amount of water exported from or imported into the watershed. Example hydrographs showing observed and reconstructed streamflow and the components of reconstructed streamflow for the Ramapo River at Pompton Lakes, N.J., and the Pompton River at Pompton Plains, N.J., are shown in figures 12 and 13 , respectively.

At the three most downstream stations in the study area--Hackensack River at New Milford, Passaic River at Route 46 at Elmwood Park, and Saddle River at Lodi--the differences between reconstructed and observed streamflow averaged over the 4-year study period were 149,483 , and 5 $\mathrm{ft}^{3} / \mathrm{s}$, respectively. Hydrographs showing observedand reconstructed-streamflow records for each of the 34 streamflow stations for both monthly and daily time steps are presented in appendixes 1 and 2 , respectively. Equations that specify how reconstructed-streamflow records were calculated for each streamflow station are presented in table 4 . This table includes only the high-volume withdrawal and discharge sites that were used in the calculation for each streamflow station.

The largest withdrawals of surface water account for much of the difference between reconstructed and observed streamflow. At the station Wanaque River at Wanaque, N.J., surface-water withdrawals from within the subwatershed averaged $129 \mathrm{Mgal} / \mathrm{d}\left(200 \mathrm{ft}^{3} / \mathrm{s}\right.$ ) (fig. 14). At Hackensack River at New Milford, N.J., surface-water withdrawals averaged $101 \mathrm{Mgal} / \mathrm{d}\left(156 \mathrm{ft}^{3} / \mathrm{s}\right)($ fig. 15). Other subwatersheds with high-volume surface-water withdrawals include Passaic River below Pompton River at Two Bridges, N.J., with withdrawals of $52.5 \mathrm{Mgal} / \mathrm{d}\left(81.2 \mathrm{ft}^{3} / \mathrm{s}\right.$ ) (fig. 16); Rockaway River below reservoir at Boonton, N.J., with a withdrawal of $45.8 \mathrm{Mgal} / \mathrm{d}\left(70.8 \mathrm{ft}^{3} / \mathrm{s}\right.$ ) (fig. 17); and Pequannock River at Macopin Intake Dam, N.J., with a withdrawal of $43.9 \mathrm{Mgal} / \mathrm{d}(67.9$ $\mathrm{ft}^{3} / \mathrm{s}$ ) (fig. 14).

Reconstructed streamflow was less than observed streamflow in only a few instances, all of which were in subwatersheds with high-volume point-source discharges from municipal treatment facilities that receive water from sources outside the subwatershed and little or no ground- or surface-water withdrawals within the subwatershed. 


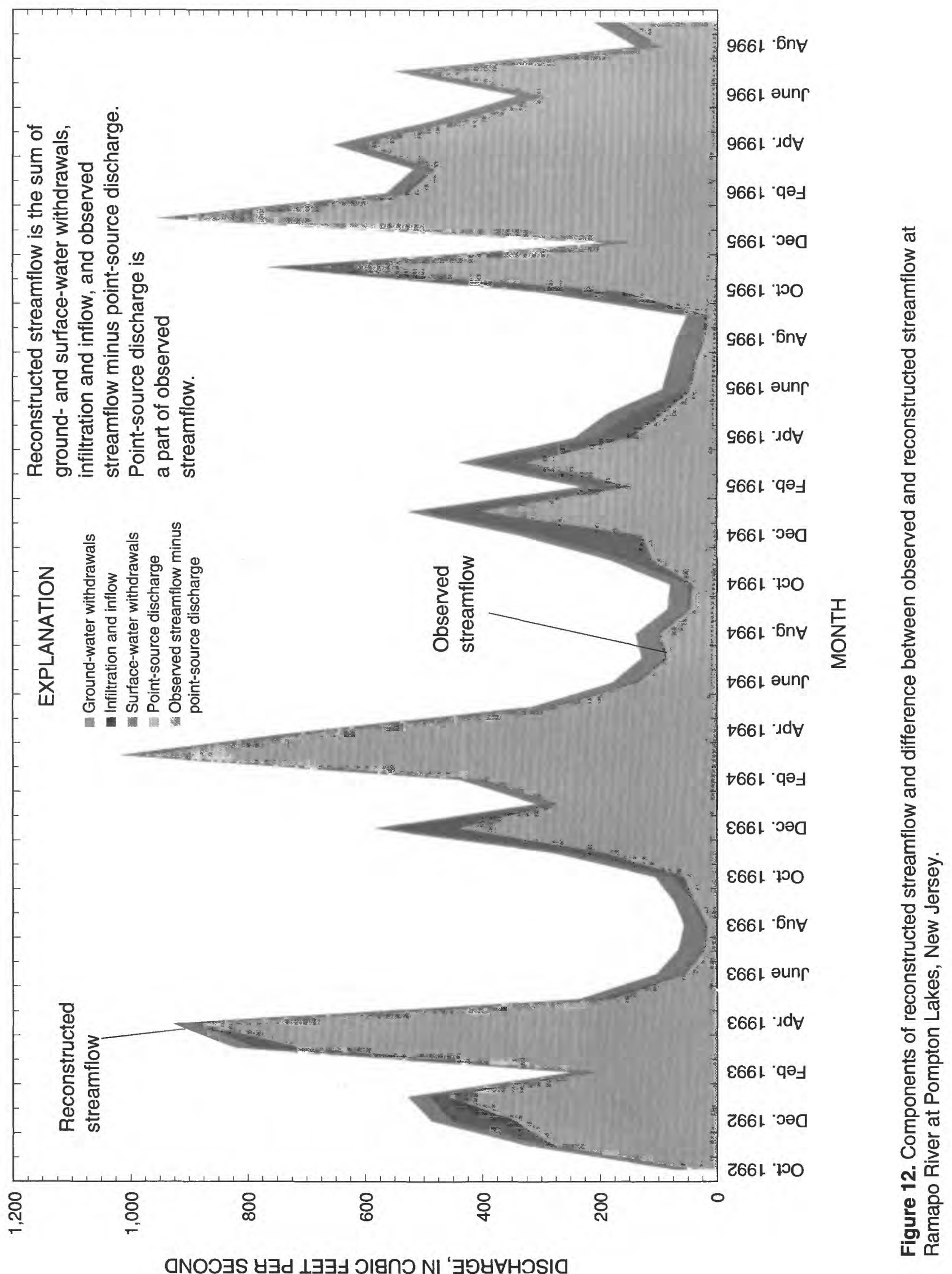




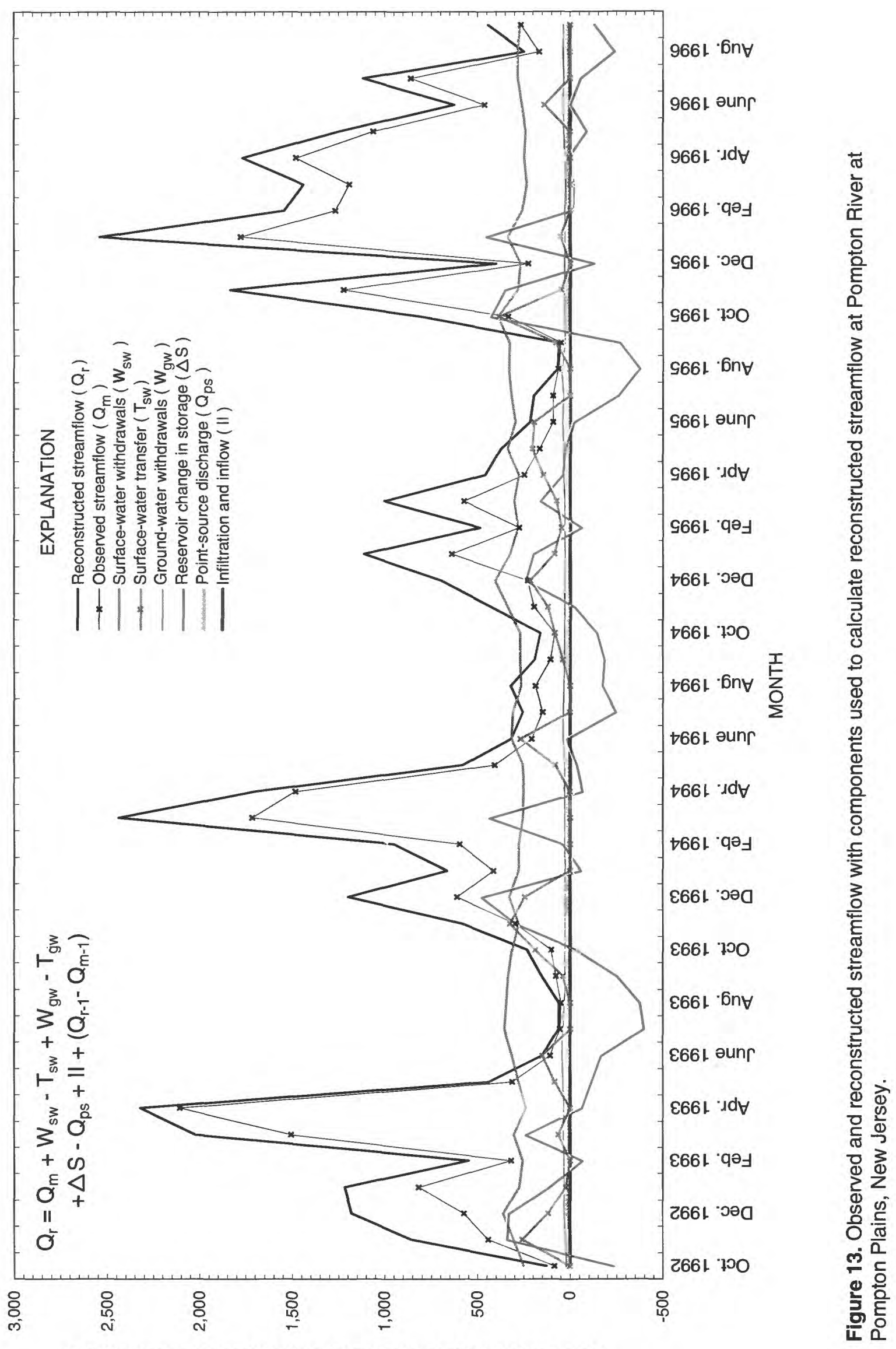

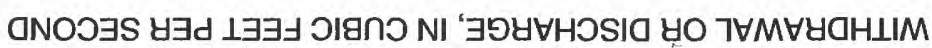


Table 4. Equations used to calculate reconstructed streamflow at gaging stations in the study area

[Only sites with discharges or withdrawals greater than 1 cubic foot per second are shown; JC, Jersey City; MUA, Municipal Utility Authority; NJDWSC, North Jersey District Water Supply Commission; PVWC, Passaic Valley Water Commission; RVRSA, Rockaway Valley Regional Sewage Authority; STP, sewage-treatment plant; Twp, township; USGS, U.S. Geological Survey; UWNJ, United Water New Jersey; UWNY, United Water New York]

USGS streamflow-gaging-station number and name Equation used to calculate reconstructed streamflow

Station 01376800

Hackensack River at West Nyack, N.Y.

Station 01377000

Hackensack River at Rivervale, N.J.

Station 01377500

Pascack Brook at Westwood, N.J.

Station 01378500

Hackensack River at New Milford, N.J.

Station 01378690

Passaic River near Bernardsville, N.J.

Station 01379000

Passaic River near Millington, N.J.

Station 01379500

Passaic River near Chatham, N.J.

Station 01379580

Passaic River near Hanover Neck, N.J.

Station 01379700

Rockaway River at Berkshire Valley, N.J.

Station 01379773

Green Pond Brook at Picatinny Arsenal, N.J.
Reconstructed streamflow = observed streamflow + change in storage in De Forest Lake + UWNY withdrawal De Forest Lake

Reconstructed streamflow = observed streamflow + change in storage in Lake Tappan + Nyack Village withdrawal - Lederle Labs ${ }^{1}$ discharge + ground-water withdrawals within subwatershed + difference between reconstructed and observed streamflow at station 01376800

Reconstructed streamflow $=$ observed streamflow + change in storage in Woodcliff Lake + ground-water withdrawals within subwatershed - ground-water transfers to surface water (UWNJ)

Reconstructed streamflow $=$ observed streamflow + change in storage in Oradell Reservoir + UWNJ withdrawal Oradell Reservoir - Sparkill Creek, Saddle River, Hirschfeld Brook, and Wanaque Reservoir transfers (UWNJ) - UWNJ discharge + ground-water withdrawals within subwatershed - ground-water transfers to surface water (UWNJ) + difference between reconstructed and observed streamflow at stations 01377000 and 01377500

Reconstructed streamflow $=$ estimated streamflow

Reconstructed streamflow $=$ observed streamflow - Chatham Twp Main and Woodland STPs discharges + ground-water withdrawals within subwatershed + difference between reconstructed and observed streamflow at station 01378690

Reconstructed streamflow = observed streamflow - Harrison Brook, Long Hill Twp, Berkeley Heights, and New Providence STPs and Reheis Chemical discharges + groundwater withdrawals within subwatershed + difference between reconstructed and observed streamflow at station 01379000

Reconstructed streamflow $=$ estimated streamflow + New Jersey American withdrawals - Molitor, Florham Park, and Livingston Twp STPs and Novartis Pharmaceutical discharges + ground-water withdrawals within subwatershed + difference between reconstructed and observed streamflow at station 01379500

Reconstructed streamflow $=$ observed streamflow

Reconstructed streamflow $=$ observed streamflow

${ }^{\mathrm{I}}$ The use of company names in this report is for identification purposes only and does not constitute endorsement by the U.S. Geological Survey. 
Table 4. Equations used to calculate reconstructed streamflow at gaging stations in the study area-Continued

USGS streamflow-gaging-station number and name

Equation used to calculate reconstructed streamflow

Station 01380500

Rockaway River above reservoir at Boonton, N.J.

Station 01381000

Rockaway River below reservoir at Boonton, N.J.

Station 01381200

Rockaway River at Pine Brook, N.J.

Station 01381500

Whippany River at Morristown, N.J.

Station 01381800

Whippany River near Pine Brook, N.J.

Station 01381900

Passaic River at Pine Brook, N.J.

Station 01382000

Passaic River at Two Bridges, N.J.

Station 01382500

Pequannock River at Macopin Intake Dam, N.J.

Station 01382800

Pequannock River at Riverdale, NJ

Station 01383500

Wanaque River at Awosting, N.J.

Station 01384500

Ringwood Creek near Wanaque, N.J.

Station 01387000

Wanaque River at Wanaque, N.J.

Station 01387400

Ramapo River at Ramapo, N.Y.

Station 01387450

Mahwah River near Suffern, N.Y.
Reconstructed streamflow $=$ observed streamflow + change in storage in Splitrock Reservoir + U.S. Army withdrawal - U.S. Army discharge + ground-water withdrawals within subwatershed + difference between reconstructed and observed streamflow at stations 01379700 and 01379773

Reconstructed streamflow $=$ observed streamflow + change in storage in Boonton Reservoir + UWNJ/JC withdrawal Boonton Reservoir + difference between reconstructed and observed streamflow at station 01380500

Reconstructed streamflow $=$ estimated streamflow - RVRSA discharge + difference between reconstructed and observed streamflow at station 01381000

Reconstructed streamflow $=$ observed streamflow + Southeast Morris County MUA withdrawal - Butterworth STP discharge

Reconstructed streamflow = estimated streamflow - Morristown and Hanover STPs discharges + ground-water withdrawals within subwatershed + difference between reconstructed and observed streamflow at station 01381500

Reconstructed streamflow $=$ observed streamflow - Parsippany-Troy Hills and Caldwell STPs discharges + ground-water withdrawals within subwatershed + difference between reconstructed and observed streamflow at stations 01379580,01381200 , and 01381800

Reconstructed streamflow = estimated streamflow + difference between reconstructed and observed streamflow at station 01381900

Reconstructed streamflow $=$ observed streamflow + change in storage in Canistear, Oak Ridge, Clinton, and Charlotteburg Reservoirs, and Echo Lake + Newark City withdrawals

Reconstructed streamflow $=$ estimated streamflow + Butler Boro withdrawals + difference between reconstructed and observed streamflow at station 01382500

Reconstructed streamflow $=$ observed streamflow + change in storage in Greenwood Lake + ground-water withdrawals within subwatershed

Reconstructed streamflow $=$ observed streamflow

Reconstructed streamflow $=$ observed streamflow + change in storage in Wanaque and Monksville Reservoirs + NJDWSC, PVWC, and UWNJ withdrawals from Wanaque Reservoir - Two Bridges and Ramapo Pumping Stations transfers (NJDWSC and UWNJ) + difference between reconstructed and observed streamflow at stations 01383500 and 01384500

Reconstructed streamflow $=$ observed streamflow + Village of Monroe withdrawals Orange County STP discharge + ground-water withdrawals within subwatershed

Reconstructed streamflow $=$ observed streamflow + ground-water withdrawals within subwatershed 
Table 4. Equations used to calculate reconstructed streamflow at gaging stations in the study area-Continued

USGS streamflow-gaging-station number and name

Equation used to calculate reconstructed streamflow

Station 01387500

Ramapo River near Mahwah, N.J.

Station 01388000

Ramapo River at Pompton Lakes, N.J.

Station 01388500

Pompton River at Pompton Plains, N.J.

Station 01388910

Pompton River at Mountain View, N.J.

\section{Station 01389005}

Passaic River below Pompton River at

Two Bridges, N.J.

Station 01389500

Passaic River at Little Falls N.J.

Station 01389880

Passaic River at Rt 46 At Elmwood Park, N.J.

\section{Station 01390500}

Saddle River at Ridgewood, N.J.

Station 01391000

Hohokus Brook at Ho-Ho-Kus, N.J.

Station 01391500

Saddle River at Lodi, N.J.
Reconstructed streamflow = observed streamflow - Suffern STP and Ramapo Valley Well Field discharges + ground-water withdrawals within subwatershed + difference between reconstructed and observed streamflow at stations 01387400 and 01387450

Reconstructed streamflow $=$ observed streamflow + change in storage in Point View Reservoir + Ramapo Pumping Station withdrawals (NJDWSC and UWNJ) - DuPont Chemicals discharge + ground-water withdrawals within subwatershed + difference between reconstructed and observed streamflow at station 01387500

Reconstructed streamflow $=$ observed streamflow + Jackson Avenue Pumping Station withdrawals - Wanaque Valley Regional and Pompton Lakes Boro STPs discharges + ground-water withdrawals within subwatershed + difference between reconstructed and observed streamflow at stations 01382800,01387000 , and 01388000

Reconstructed streamflow $=$ estimated streamflow + ground-water withdrawals within subwatershed + difference between reconstructed and observed streamflow at station 01388500

Reconstructed streamflow $=$ estimated streamflow + Two Bridges Pumping Station withdrawals (NJDWSC, PVWC, and UWNJ) - Two Bridges STP discharge + difference between reconstructed and observed streamflow at stations 01382000 and 01388910

Reconstructed streamflow $=$ observed streamflow + PVWC withdrawal - Mountain View STP discharge + difference between reconstructed and observed streamflow at station 01389005

Reconstructed streamflow $=$ estimated streamflow + Marcel withdrawal - Verona and Cedar Grove STPs and PVWC discharges + ground-water withdrawals within subwatershed + difference between reconstructed and observed streamflow at station 01389500

Reconstructed streamflow $=$ observed streamflow + ground-water withdrawals within subwatershed

Reconstructed streamflow $=$ observed streamflow - Northwest Bergen County STP discharge + ground-water withdrawals within subwatershed

Reconstructed streamflow $=$ observed streamflow + UWNJ and Stepan Chemical withdrawals - Ridgewood Village STP discharge + ground-water withdrawals within subwatershed + difference between reconstructed and observed streamflow at stations 01390500 and 01391000 


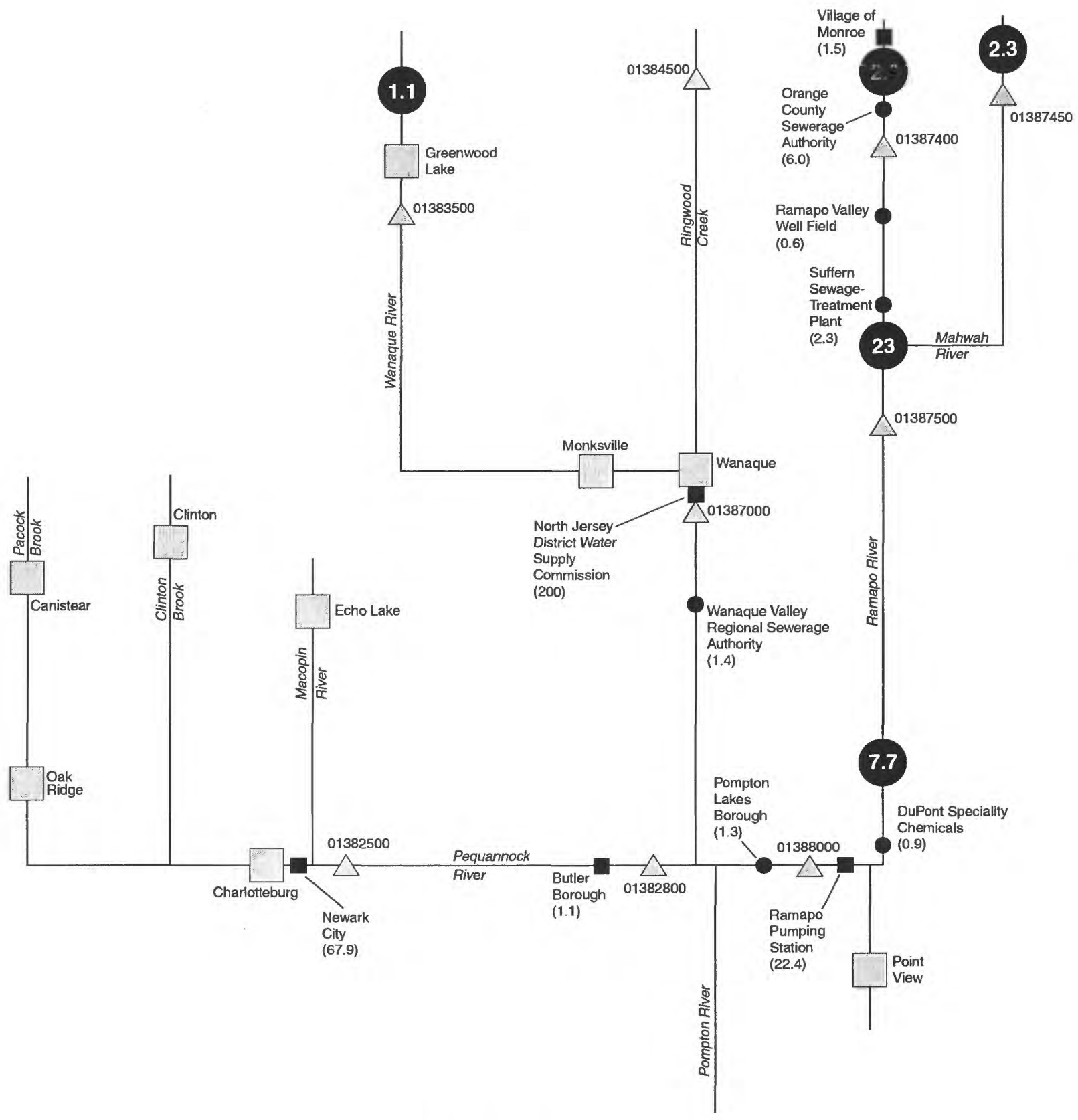

EXPLANATION

Reservoir

River or stream

${ }^{01384500} \triangle$ Streamflow-gaging station and number

Pompton

Lakes

Borough

(1.3)
Point-source-discharge site and name-Number is $1993-96$ average monthly discharge from all outfall pipes, in cubic feet per second

Ground-water withdrawal--Number is 1993-96 average monthly withdrawal from wells in subwatershed, in cubic feet per second

Butler

Borough

(1.1)
Surface-water-withdrawal site and name-Number is 1993-96 average monthly withdrawal, in cubic feet per second

Figure 14. Schematic diagram showing relation of high-volume point-source-discharge sites and surface-water- and ground-water-withdrawal sites to streamflow-gaging stations and reservoirs in the Pequannock, Wanaque, and Ramapo River Basins, New Jersey and New York. 


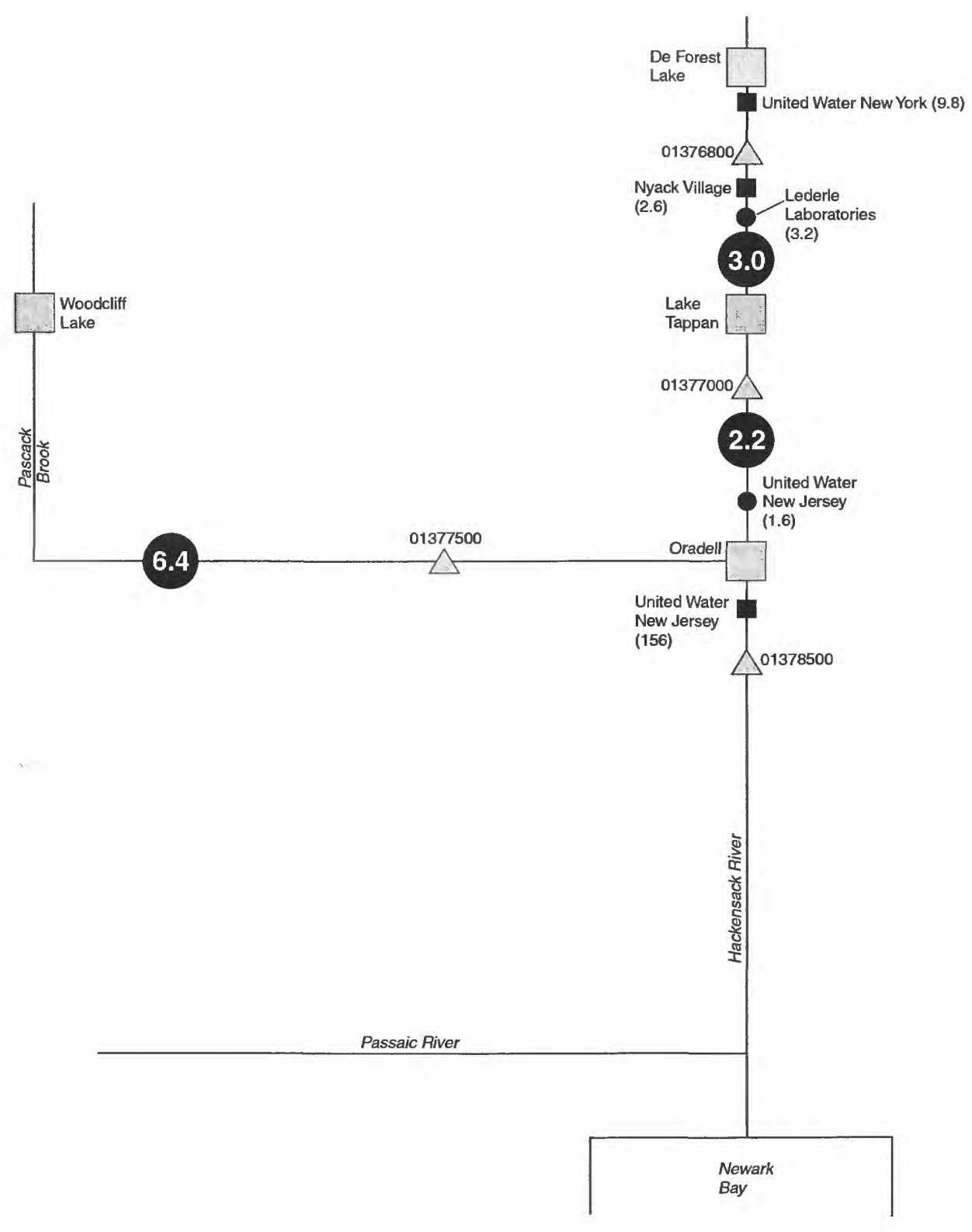

EXPLANATION

Reservoir

River or stream

Streamflow-gaging station and number

Lederle Laboratories (3.2)
Point-source-discharge site and name-Number is 1993-96 average monthly discharge from all outfall pipes, in cubic feet per second
Ground-water withdrawal--Number

6.4 is 1993-96 average monthly withdrawal from wells in subwatershed, in cubic feet per second

Nyack Village Surface-water-withdrawal site and name-Number is 1993-96 average monthly withdrawal, in cubic feet per second

Figure 15. Schematic diagram showing relation of high-volume point-source-discharge sites and surface-water- and ground-water-withdrawal sites to streamflow-gaging stations and reservoirs in the Hackensack River Basins, New Jersey and New York. 


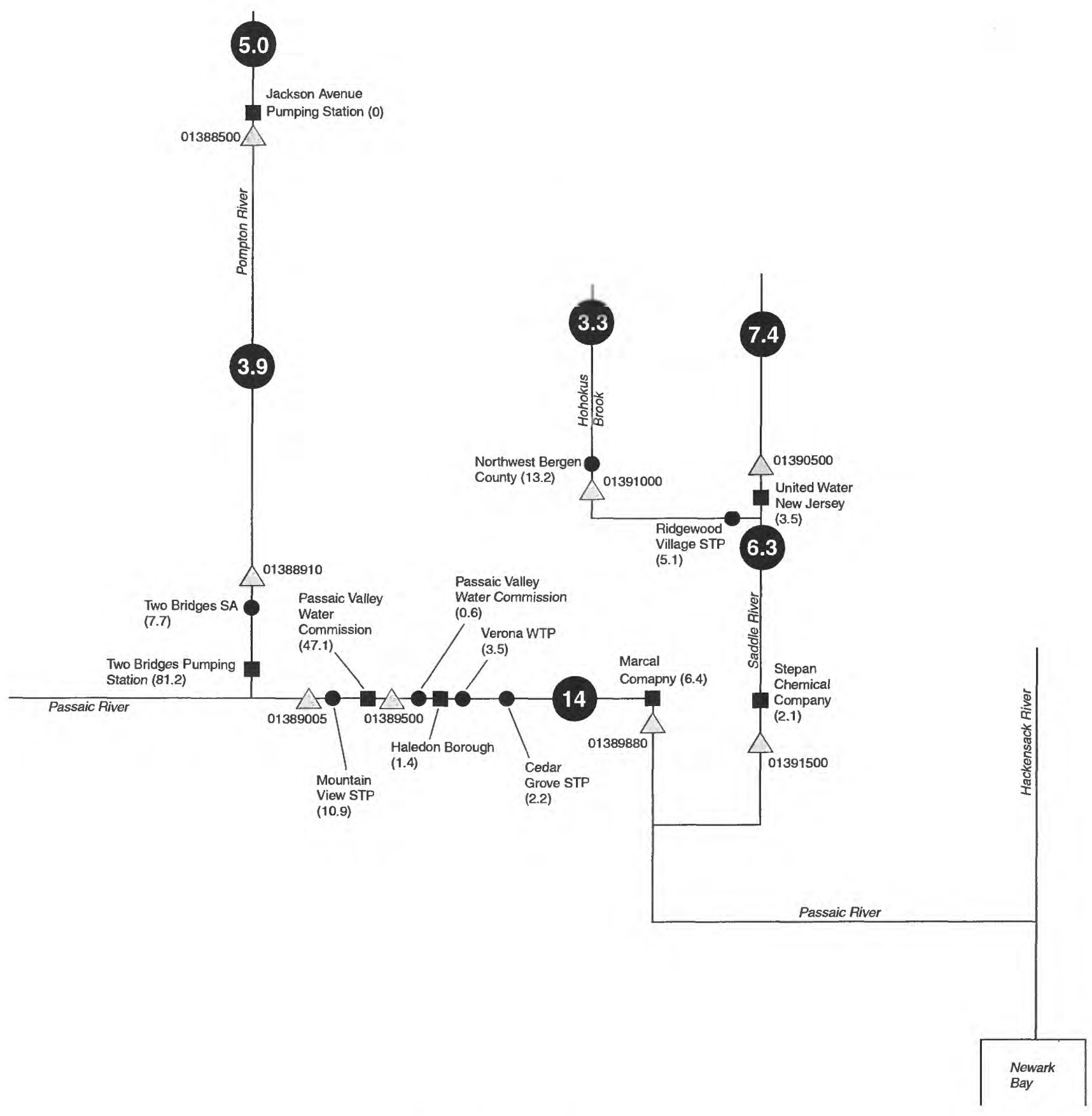

EXPLANATION

$\begin{array}{ll}\square & \begin{array}{l}\text { Reservoir } \\ \text { River or stream }\end{array} \\ \begin{array}{l}\text { Ridgewood } \\ \text { Village STP }\end{array} & \begin{array}{l}\text { Point-source-discharge site and name-- } \\ \text { (5.1) }\end{array} \\ & \begin{array}{l}\text { Number is 1993-96 average monthly } \\ \text { feet per second }\end{array}\end{array}$

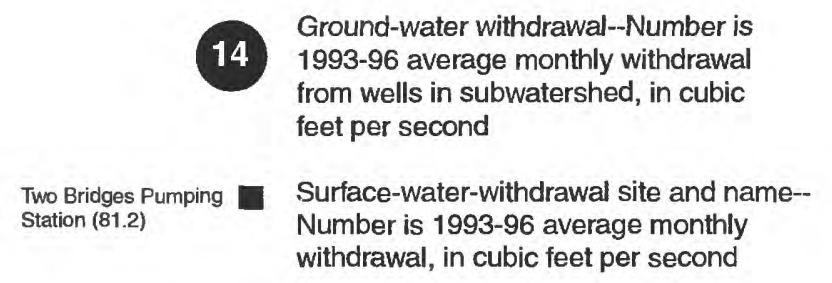

(14) Ground-water withdrawal--Number is 1993-96 average monthly withdrawal from wells in subwatershed, in cubic Surface-water-withdrawal site and name-withdrawal, in cubic feet per second

Figure 16. Schematic diagram showing relation of high-volume point-source-discharge sites and surface-water- and ground-water-withdrawal sites to streamflow-gaging stations in the Pompton, Lower Passaic, and Saddle River Basins, New Jersey. (SA, sewerage authority; STP, sewagetreatment plant; WTP, water-treatment plant) 

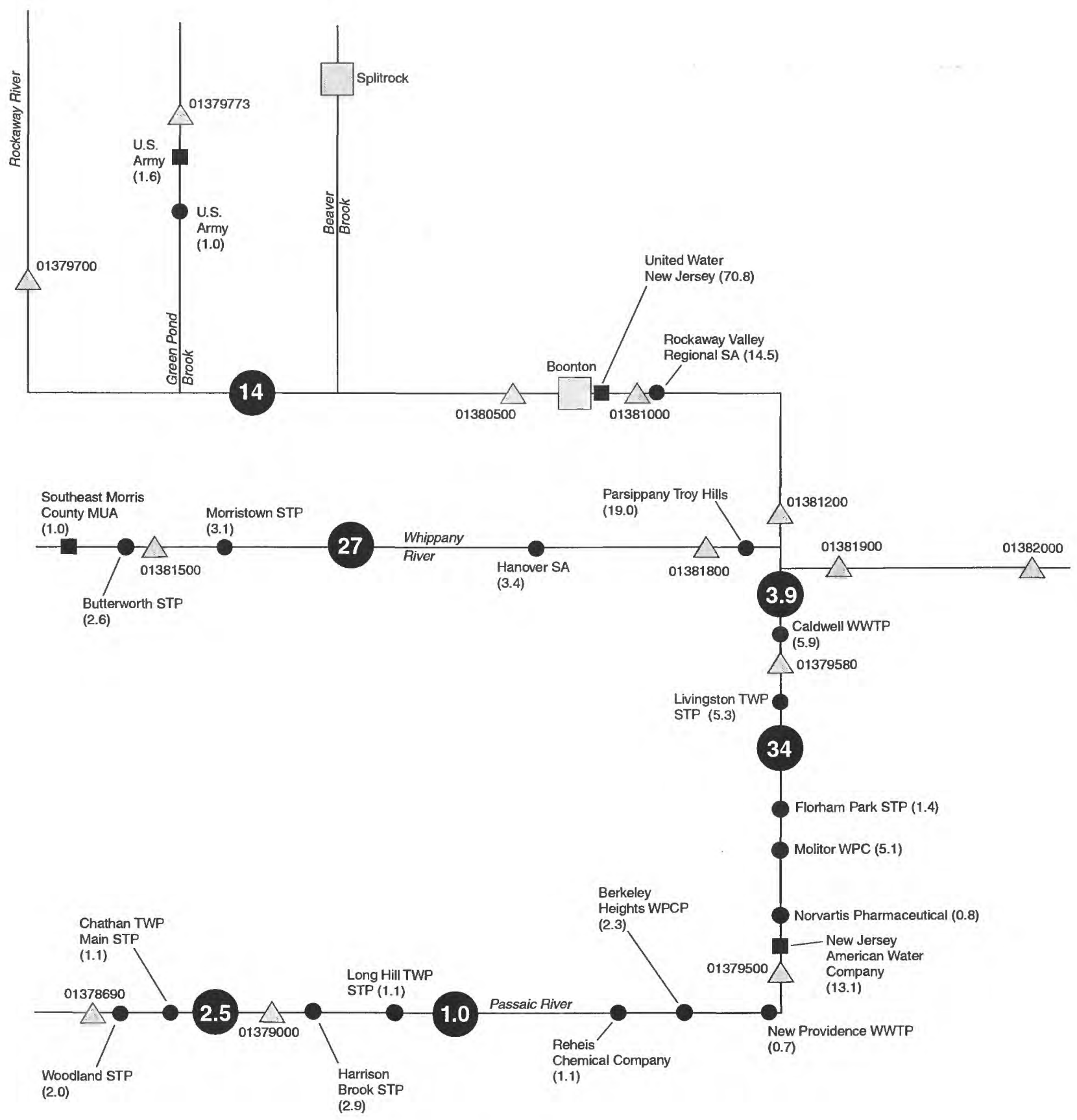

EXPLANATION

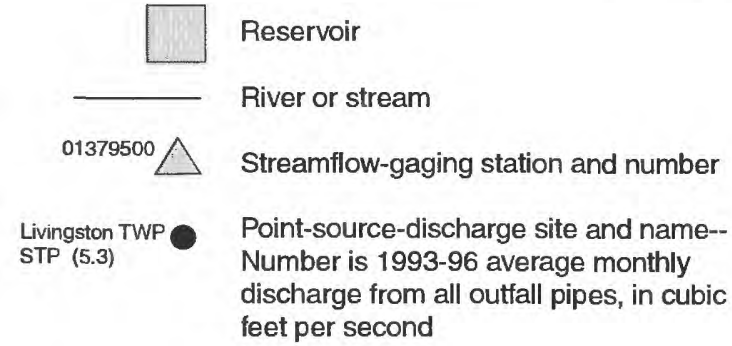
34 1993-96 average monthly withdrawal from wells in subwatershed, in cubic feet per second
U.S.

Army
(1.6)
Surface-water-withdrawal site and name-Number is 1993-96 average monthly withdrawal, in cubic feet per second

Figure 17. Schematic diagram showing relation of high-volume point-source-discharge sites and surface-water- and ground-water-withdrawal sites to streamflow-gaging stations and reservoirs in the Rockaway, Whippany, and Upper Passaic River Basins, New Jersey. (MUA, municipal utilities authority; SA, sewerage authority; STP, sewage-treatment plant; TWP, township; WPC, waterpollution control; WPCP, water-pollution-control plant; WWTP, wastewater-treatment plant) 
The average difference between reconstructed and observed streamflow at the station HoHoKus Brook at Ho-Ho-Kus, N.J., was $-9.8 \mathrm{ft}^{3} / \mathrm{s}$ (fig. 16); the average difference at Passaic River near Chatham, N.J., was $-7.5 \mathrm{ft}^{3} / \mathrm{s}$ (fig. 17).

Reconstructed streamflow was nearly equal to observed streamflow in several upstream reaches of the basins--Passaic River near Bernardsville, N.J.; Ringwood Creek near Wanaque, N.J.; Rockaway River at Berkshire Valley, N.Y.; Mahwah River near Suffern, N.Y.; and Passaic River near Millington, N.J. This result is reasonable because few human influences were present in these subwatersheds. Thesé reaches are subject to few permitted withdrawals or discharges, and contain no reservoirs. For the most part, the only factors likely to affect streamflow are domestic withdrawals and septic-system discharges, which were not considered in this study. The number of surface-water-withdrawal, ground-water-withdrawal, and point-source-discharge sites and reservoirs used to reconstruct streamflow records, mean withdrawals and discharges, and additional statistics for each of the 34 streamflow-gaging stations are summarized in table 5 .

\section{Evaluation of Reconstructed-Stream- flow Records}

Reconstructed-streamflow records for each station were compared to those for the other stations to determine whether the results are consistent and whether they are reasonable estimates of natural streamflow. The sum of ground-water and surface-water withdrawals was compared to the sum of point-source discharges to determine whether data compilation was complete and accurate. Water balances were calculated for the three most downstream stations as an additional check on the reconstructed-streamflow records.

\section{Methods Used to Evaluate Recon- structed-Streamflow Records}

Streamflow depends on rainfall, evaporation, transpiration, and the other factors that determine runoff. Generally, streamflow is greatest during spring, and declines during summer when evapotranspiration and water use are greater, even though rainfall is fairly constant througho"t the year. Streamflow typically recovers in autumn, and increases during the winter months. By ncrmalizing streamflow to drainage area (cubic feet per second per square mile), streamflow values c`n be compared for consistency among stations. Analysis of monthly, rather than daily, reconstructed-streamflow values also tends to normalize variat ins in rainfall. Therefore, monthly streamflow values at selected stations were compared to those at stations in other subwatersheds in the study area.

Reconstructed-streamflow values were analyzed to ensure that they were reasonable estimates of what streamflow would have been without major influences due to human activities. One method used to assess reconstructed streamflow was to compare values at adjacent stations. In general, streamflow increases downstream. T' is is not always true, however, because a stream may lose water to recharge areas and wetlands in sc me reaches by natural means. Wetlands tend to reduce the magnitude of streamflow peaks during storms by allowing water to go into storage. Then, during dry periods, water is released from storage and streamflow is greater than would be expected if wetlands were not present. In some areas, groundwater withdrawals may induce surface water to flow into the aquifer as recharge.

In several subwatersheds, reconstructed streamflow decreased downstream for brief periods. Although this situation can occur nat rally in recharge areas and wetlands, the reason for this occurrence was unknown in some cases. Stage-discharge relations may be inaccurate at peak stages at several stations where peak streamflow is rarely measured. Stations at which reconstructec' streamflow was greater upstream than downstresm are Hackensack River at Riverdale, N.J.; Roc'`away River below reservoir at Boonton, N.J.; Passaic River at Pine Brook, N.J.; Pequannock River at Macopin Intake Dam, N.J.; Pequannock F iver at Riverdale, N.J.; Passaic River below Pompton River at Two Bridges, N.J.; and Passaic River at Little Falls, N.J.

Another method used to evaluate re-onstructed streamflow was to compare the discharges at individual stations by season. Values were 
Table 5. Summary of surface-water-withdrawal, ground-water-withdrawal, and point-source-discharge sites and reservoirs used to reconstruct streamflow records, mean withdrawals and discharges, and additional statistics, Passaic and Hackensack River Basins, New Jersey and New York

[USGS, U.S. Geological Survey; --, not available; -, not applicable; <, less than]

\begin{tabular}{|c|c|c|c|c|c|c|}
\hline \multirow{2}{*}{$\begin{array}{c}\text { USGS } \\
\text { streamflow- } \\
\text { gaging- } \\
\text { station } \\
\text { number } \\
\end{array}$} & \multirow[b]{2}{*}{ Station name } & \multicolumn{4}{|c|}{ Number of sites in subwatershed } & \multirow[b]{2}{*}{$\begin{array}{c}\text { Nuriber of } \\
\text { upstream } \\
\text { gering } \\
\text { stctions }\end{array}$} \\
\hline & & $\begin{array}{l}\text { Surface- } \\
\text { water- } \\
\text { with- } \\
\text { drawal }\end{array}$ & Wells & $\begin{array}{l}\text { Point- } \\
\text { source- } \\
\text { discharge }\end{array}$ & $\begin{array}{c}\text { Reser- } \\
\text { voirs }\end{array}$ & \\
\hline 01376800 & Hackensack River at West Nyack, N.Y. & 1 & 5 & 2 & 1 & 0 \\
\hline 01377000 & Hackensack River at Rivervale, N.J. & 2 & 14 & 3 & 1 & 1 \\
\hline 01377500 & Pascack Brook at Westwood, N.J. & 1 & 28 & 2 & 1 & 0 \\
\hline 01378500 & Hackensack River at New Milford, N.J. & 4 & 25 & 9 & 1 & 3 \\
\hline 01378690 & Passaic River near Bernardsville, N.J. & 2 & 5 & 0 & 0 & 0 \\
\hline 01379000 & Passaic River near Millington, N.J. & 2 & 20 & 9 & 0 & 1 \\
\hline 01379500 & Passaic River near Chatham, N.J. & 0 & 9 & 17 & 0 & 2 \\
\hline 01379580 & Passaic River near Hanover Neck, N.J. & 8 & 81 & 30 & 0 & $\overline{3}$ \\
\hline 01379700 & Rockaway River at Berkshire Valley, N.J. & 1 & 14 & 3 & 0 & 0 \\
\hline 01379773 & Green Pond Brook at Picatinny Arsenal, N.J. & 1 & 0 & 0 & 0 & 0 \\
\hline 01380500 & Rockaway River above reservoir at Boonton, N.J. & 11 & 69 & 37 & 1 & 2 \\
\hline 01381000 & Rockaway River below reservoir at Boonton. N.J. & 1 & 0 & 0 & 1 & 3 \\
\hline 01381200 & Rockaway River at Pine Brook, N.J. & 4 & 1 & 4 & 0 & 4 \\
\hline 01381500 & Whippany River at Morristown, N.J. & 1 & 15 & 16 & 0 & 0 \\
\hline 01381800 & Whippany River near Pine Brook, N.J. & 2 & 74 & 35 & 0 & 1 \\
\hline 01381900 & Passaic River at Pine Brook, N.J. & 0 & 18 & 13 & 0 & 11 \\
\hline 01382000 & Passaic River at Two Bridges, N.J. & 0 & 6 & 1 & 0 & 12 \\
\hline 01382500 & Pequannock River at Macopin Intake Dam, N.J. & 1 & 8 & 3 & 5 & 0 \\
\hline 01382800 & Pequannock River at Riverdale, N.J. & 1 & 1 & 10 & 0 & 1 \\
\hline 01383500 & Wanaque River at Awosting, N.J. & 0 & 41 & 9 & 1 & 0 \\
\hline 01384500 & Ringwood Creek near Wanaque, N.J. & 2 & 1 & 1 & 0 & 0 \\
\hline 01387000 & Wanaque River at Wanaque, N.J. & 1 & 8 & 2 & 2 & 2 \\
\hline 01387400 & Ramapo River at Ramapo, N.Y. & 6 & 30 & 14 & 0 & 0 \\
\hline 01387450 & Mahwah River near Suffern, N.Y. & 0 & 3 & 0 & 0 & 0 \\
\hline 01387500 & Ramapo River near Mahwah, N.J. & 1 & 40 & 16 & 0 & 2 \\
\hline 01388000 & Ramapo River at Pompton Lakes, N.J. & 4 & 46 & 10 & 1 & 3 \\
\hline 01388500 & Pompton River at Pompton Plains, N.J. & 5 & 16 & 17 & 0 & 9 \\
\hline 01388910 & Pompton River at Mountain View, N.J. & 4 & 18 & 4 & 0 & 10 \\
\hline 01389005 & Passaic River below Pompton R. at Two Bridges, N.J. & 3 & 0 & 2 & 0 & 24 \\
\hline 01389500 & Passaic River at Little Falls, N.J. & 5 & 17 & 28 & 0 & 25 \\
\hline 01389880 & Passaic River at Rt. 46 at Elmwood Park, N.J. & 6 & 125 & 55 & 0 & 26 \\
\hline 01390500 & Saddle River at Ridgewood, N.J. & 1 & 21 & 2 & 0 & 0 \\
\hline 01391000 & Hohokus Brook at Ho-Ho-Kus, N.J. & 0 & 36 & 8 & 0 & 0 \\
\hline 01391500 & Saddle River at Lodi, N.J. & 6 & 41 & 6 & 0 & 2 \\
\hline
\end{tabular}


Table 5. Summary of surface-water-withdrawal, ground-water-withdrawal, and point-source-discharge sites and reservoirs used to reconstruct streamflow records, mean withdrawals and discharges, and additional statistics, Passaic and Hackensack River Basins, New Jersey and New York--Continued

\begin{tabular}{|c|c|c|c|c|c|c|}
\hline \multirow{2}{*}{$\begin{array}{c}\text { USGS } \\
\text { stream- } \\
\text { flow- } \\
\text { gaging- } \\
\text { station } \\
\text { number }\end{array}$} & \multicolumn{3}{|c|}{$\begin{array}{l}\text { Observed streamflow, } \\
\text { in cubic feet per second }\end{array}$} & \multicolumn{3}{|c|}{$\begin{array}{l}\text { Reconstructed streamflow, } \\
\text { in cubic feet per second }\end{array}$} \\
\hline & Minimum & Mean & Maximum & Minimum & Mean & Maxiๆum \\
\hline $\begin{array}{l}01376800 \\
01377000 \\
01377500 \\
01378500 \\
01378690\end{array}$ & $\begin{array}{r}12.2 \\
15.4 \\
20.0 \\
.3 \\
4.1\end{array}$ & $\begin{array}{l}40.9 \\
83.0 \\
49.5 \\
50.2 \\
17.6\end{array}$ & $\begin{array}{c}139 \\
235 \\
109 \\
316 \\
55.7\end{array}$ & $\begin{array}{r}2.5 \\
1.8 \\
19.6 \\
34.0 \\
4.3\end{array}$ & $\begin{array}{c}51.4 \\
94.9 \\
55.8 \\
199 \\
17.8\end{array}$ & $\begin{array}{c}161 \\
276 \\
115 \\
529 \\
55.9\end{array}$ \\
\hline $\begin{array}{l}01379000 \\
01379500 \\
01379580 \\
01379700 \\
01379773\end{array}$ & $\begin{array}{r}9.4 \\
21.4 \\
30.6 \\
3.4 \\
1.8\end{array}$ & $\begin{array}{c}95.6 \\
177 \\
226 \\
56.5 \\
13.8\end{array}$ & $\begin{array}{c}439 \\
719 \\
875 \\
190 \\
45.5\end{array}$ & $\begin{array}{r}10.6 \\
19.3 \\
55.0 \\
4.0 \\
1.8\end{array}$ & $\begin{array}{c}95.8 \\
170 \\
253 \\
56.9 \\
13.9\end{array}$ & $\begin{array}{l}438 \\
706 \\
900 \\
190 \\
45.7\end{array}$ \\
\hline $\begin{array}{l}01380500 \\
01381000 \\
01381200 \\
01381500 \\
01381800\end{array}$ & $\begin{array}{l}27.2 \\
10.1 \\
27.6 \\
19.8 \\
33.4\end{array}$ & $\begin{array}{l}237 \\
169 \\
218 \\
63.5 \\
125\end{array}$ & $\begin{array}{l}722 \\
713 \\
839 \\
181 \\
369\end{array}$ & $\begin{array}{l}39.9 \\
17.6 \\
23.0 \\
17.7 \\
58.7\end{array}$ & $\begin{array}{l}254 \\
257 \\
293 \\
62.5 \\
144\end{array}$ & $\begin{array}{l}745 \\
794 \\
901 \\
180 \\
387\end{array}$ \\
\hline $\begin{array}{l}01381900 \\
01382000 \\
01382500 \\
01382800 \\
01383500\end{array}$ & $\begin{array}{l}126 \\
130 \\
1.0 \\
5.5 \\
3.9\end{array}$ & $\begin{array}{c}651 \\
673 \\
67.6 \\
101 \\
55.3\end{array}$ & $\begin{array}{r}2,200 \\
2,280 \\
342 \\
453 \\
218\end{array}$ & $\begin{array}{c}172 \\
177 \\
-4.1 \\
4.3 \\
-9.4\end{array}$ & $\begin{array}{c}752 \\
774 \\
140 \\
174 \\
56.3\end{array}$ & $\begin{array}{r}2,310 \\
2,390 \\
449 \\
540 \\
232\end{array}$ \\
\hline $\begin{array}{l}01384500 \\
01387000 \\
01387400 \\
01387450 \\
01387500\end{array}$ & $\begin{array}{r}.9 \\
7.7 \\
11.3 \\
.9 \\
11.3\end{array}$ & $\begin{array}{c}34.0 \\
41.5 \\
172 \\
22.1 \\
230\end{array}$ & $\begin{array}{c}122 \\
357 \\
594 \\
74.0 \\
740\end{array}$ & $\begin{array}{r}1.4 \\
-43.1 \\
12.5 \\
3.2 \\
26.4\end{array}$ & $\begin{array}{c}34.2 \\
168 \\
171 \\
24.4 \\
250\end{array}$ & $\begin{array}{l}122 \\
630 \\
591 \\
76.5 \\
757\end{array}$ \\
\hline $\begin{array}{l}01388000 \\
01388500 \\
01388910 \\
01389005 \\
01389500\end{array}$ & $\begin{array}{c}14.7 \\
49.8 \\
56.9 \\
148 \\
78.6\end{array}$ & $\begin{array}{r}280 \\
536 \\
646 \\
1,060 \\
1,020\end{array}$ & $\begin{array}{r}979 \\
2,110 \\
2,570 \\
3,400 \\
3,670\end{array}$ & $\begin{array}{l}39.6 \\
60.8 \\
74.6 \\
245 \\
252\end{array}$ & $\begin{array}{r}330 \\
788 \\
902 \\
1,490 \\
1,490\end{array}$ & $\begin{array}{l}1,000 \\
2,540 \\
2,950 \\
4,150 \\
4,360\end{array}$ \\
\hline $\begin{array}{l}01389880 \\
01390500 \\
01391000 \\
01391500\end{array}$ & $\begin{array}{r}87.9 \\
2.7 \\
15.1 \\
19.3\end{array}$ & $\begin{array}{c}1,060 \\
29.9 \\
40.1 \\
100\end{array}$ & $\begin{array}{r}3,760 \\
87.5 \\
93.4 \\
256\end{array}$ & $\begin{array}{r}290 \\
9.8 \\
5.6 \\
33.8\end{array}$ & $\begin{array}{c}1,550 \\
37.3 \\
30.3 \\
105\end{array}$ & $\begin{array}{c}4,460 \\
94.1 \\
82.5 \\
254\end{array}$ \\
\hline
\end{tabular}


Table 5. Summary of surface-water-withdrawal, ground-water-withdrawal, and point-source-discharge sites and raservoirs used to reconstruct streamflow records, mean withdrawals and discharges, and additional statistics, Passaic and Hackensack River Basins, New Jersey and New York--Continued

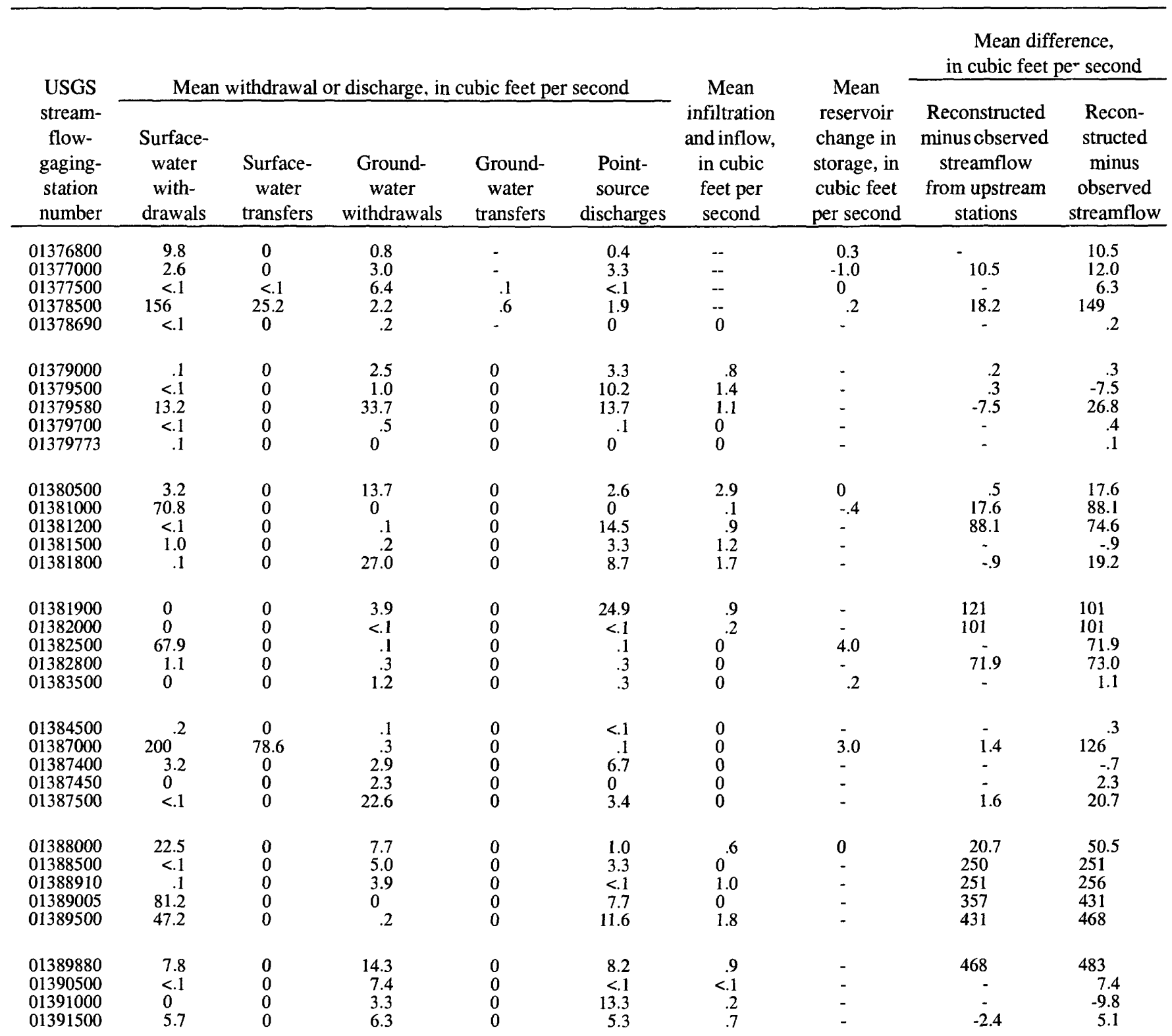


Table 5. Summary of surface-water-withdrawal, ground-water-withdrawal, and point-sourcedischarge sites and reservoirs used to reconstruct streamflow records, mean withdrawals and discharges, and additional statistics, Passaic and Hackensack River Basins, New Jersey and New York--Continued

\begin{tabular}{|c|c|c|c|c|c|c|c|c|c|}
\hline \multirow{2}{*}{$\begin{array}{c}\text { USGS } \\
\text { streamflow- } \\
\text { gaging- } \\
\text { station } \\
\text { number } \\
\end{array}$} & \multicolumn{8}{|c|}{ Mean withdrawal or discharge, in cubic feet per second per square mile } & \multirow[b]{2}{*}{$\begin{array}{c}\text { Drainage } \\
\text { area, in } \\
\text { square } \\
\text { miles } \\
\end{array}$} \\
\hline & $\begin{array}{c}\text { Surface- } \\
\text { water } \\
\text { withdrawals }\end{array}$ & $\begin{array}{c}\text { Surface- } \\
\text { water } \\
\text { transfers }\end{array}$ & $\begin{array}{c}\begin{array}{c}\text { Ground- } \\
\text { water } \\
\text { withdrawals }\end{array} \\
\end{array}$ & $\begin{array}{c}\text { Ground- } \\
\text { water } \\
\text { transfers }\end{array}$ & $\begin{array}{c}\text { Point- } \\
\text { source } \\
\text { discharges }\end{array}$ & $\begin{array}{l}\text { Infiltra- } \\
\text { tion and } \\
\text { inflow }\end{array}$ & $\begin{array}{c}\text { Observed } \\
\text { streamflow }\end{array}$ & $\begin{array}{c}\text { Recon- } \\
\text { structed } \\
\text { streamflow }\end{array}$ & \\
\hline $\begin{array}{l}01376800 \\
01377000 \\
01377500 \\
01378500 \\
01378690\end{array}$ & $\begin{array}{l}0.320 \\
.215 \\
<.001 \\
1.49 \\
<.001\end{array}$ & $\begin{array}{l}0 \\
0 \\
0 \\
0.223 \\
0\end{array}$ & $\begin{array}{l}0.025 \\
.066 \\
.216 \\
.110 \\
.026\end{array}$ & $\begin{array}{l}0 \\
0 \\
.003 \\
.006 \\
0\end{array}$ & $\begin{array}{l}0.014 \\
.063 \\
<.001 \\
.049 \\
0\end{array}$ & $\begin{array}{l}-- \\
-- \\
- \\
\ddot{0}\end{array}$ & $\begin{array}{l}1.332 \\
1.431 \\
1.673 \\
.444 \\
1.995\end{array}$ & $\begin{array}{l}1.674 \\
1.637 \\
1.886 \\
1.761 \\
2.021\end{array}$ & $\begin{array}{c}30.7 \\
58 \\
29.6 \\
113 \\
8.83\end{array}$ \\
\hline $\begin{array}{l}01379000 \\
01379500 \\
01379580 \\
01379700 \\
01379773\end{array}$ & $\begin{array}{l}.001 \\
.001 \\
.101 \\
.001 \\
.011\end{array}$ & $\begin{array}{l}0 \\
0 \\
0 \\
0 \\
0\end{array}$ & $\begin{array}{l}.050 \\
.038 \\
.284 \\
.020 \\
0\end{array}$ & $\begin{array}{l}0 \\
0 \\
0 \\
0 \\
0\end{array}$ & $\begin{array}{l}.060 \\
.135 \\
.206 \\
.005 \\
0\end{array}$ & $\begin{array}{l}.014 \\
.022 \\
.025 \\
0 \\
0\end{array}$ & $\begin{array}{l}1.725 \\
1.772 \\
1.710 \\
2.317 \\
1.800\end{array}$ & $\begin{array}{l}1.730 \\
1.697 \\
1.913 \\
2.333 \\
1.811\end{array}$ & $\begin{array}{c}55.4 \\
100 \\
132 \\
24.4 \\
7.65\end{array}$ \\
\hline $\begin{array}{l}01380500 \\
01381000 \\
01381200 \\
01381500 \\
01381800\end{array}$ & $\begin{array}{l}.029 \\
.623 \\
.545 \\
.033 \\
.015\end{array}$ & $\begin{array}{l}0 \\
0 \\
0 \\
0 \\
0\end{array}$ & $\begin{array}{l}.122 \\
.119 \\
.105 \\
.007 \\
.397\end{array}$ & $\begin{array}{l}0 \\
0 \\
0 \\
0 \\
0\end{array}$ & $\begin{array}{l}.024 \\
.023 \\
.123 \\
.113 \\
.175\end{array}$ & $\begin{array}{l}.025 \\
.025 \\
.028 \\
.041 \\
.043\end{array}$ & $\begin{array}{l}2.041 \\
1.420 \\
1.604 \\
2.159 \\
1.829\end{array}$ & $\begin{array}{l}2.193 \\
2.160 \\
2.153 \\
2.127 \\
2.109\end{array}$ & $\begin{array}{c}116 \\
119 \\
136 \\
29.4 \\
68.5\end{array}$ \\
\hline $\begin{array}{l}01381900 \\
01382000 \\
01382500 \\
01382800 \\
01383500\end{array}$ & $\begin{array}{l}.254 \\
.245 \\
1.07 \\
.822 \\
0\end{array}$ & $\begin{array}{l}0 \\
0 \\
0 \\
0 \\
0\end{array}$ & $\begin{array}{l}.237 \\
.229 \\
.002 \\
.006 \\
.042\end{array}$ & $\begin{array}{l}0 \\
0 \\
0 \\
0 \\
0\end{array}$ & $\begin{array}{l}.233 \\
.225 \\
.002 \\
.004 \\
.011\end{array}$ & $\begin{array}{l}.032 \\
.031 \\
0 \\
0\end{array}$ & $\begin{array}{l}1.866 \\
1.865 \\
1.062 \\
1.207 \\
2.039\end{array}$ & $\begin{array}{l}2.154 \\
2.144 \\
2.191 \\
2.077 \\
2.078\end{array}$ & $\begin{array}{r}349 \\
361 \\
63.7 \\
83.9 \\
27.1\end{array}$ \\
\hline $\begin{array}{l}01384500 \\
01387000 \\
01387400 \\
01387450 \\
01387500\end{array}$ & $\begin{array}{l}.009 \\
2.22 \\
.037 \\
0 \\
.027\end{array}$ & $\begin{array}{l}0 \\
.870 \\
0 \\
0 \\
0\end{array}$ & $\begin{array}{l}.005 \\
.018 \\
.033 \\
.186 \\
.231\end{array}$ & $\begin{array}{l}0 \\
0 \\
0 \\
0 \\
0\end{array}$ & $\begin{array}{c}<.001 \\
.005 \\
.078 \\
0 \\
.085\end{array}$ & $\begin{array}{l}0 \\
0 \\
0 \\
0 \\
0\end{array}$ & $\begin{array}{r}1.778 \\
.459 \\
1.981 \\
1.796 \\
1.913\end{array}$ & $\begin{array}{l}1.792 \\
1.853 \\
1.973 \\
1.982 \\
2.086\end{array}$ & $\begin{array}{r}19.1 \\
90.4 \\
86.9 \\
12.3 \\
120\end{array}$ \\
\hline $\begin{array}{l}01388000 \\
01388500 \\
01388910 \\
01389005 \\
01389500\end{array}$ & $\begin{array}{l}.161 \\
.831 \\
.795 \\
.633 \\
.672\end{array}$ & $\begin{array}{l}0 \\
.222 \\
.212 \\
.107 \\
.103\end{array}$ & $\begin{array}{l}.221 \\
.120 \\
.125 \\
.176 \\
.170\end{array}$ & $\begin{array}{l}0 \\
0 \\
0 \\
0 \\
0\end{array}$ & $\begin{array}{l}.070 \\
.043 \\
.041 \\
.142 \\
.152\end{array}$ & $\begin{array}{l}.003 \\
.002 \\
.004 \\
.017 \\
.019\end{array}$ & $\begin{array}{l}1.749 \\
1.511 \\
1.741 \\
1.438 \\
1.336\end{array}$ & $\begin{array}{l}2.065 \\
2.219 \\
2.431 \\
2.025 \\
1.951\end{array}$ & $\begin{array}{l}160 \\
355 \\
371 \\
734 \\
762\end{array}$ \\
\hline $\begin{array}{l}01389880 \\
01390500 \\
01391000 \\
01391500\end{array}$ & $\begin{array}{l}.647 \\
<.001 \\
0 \\
.105\end{array}$ & $\begin{array}{l}.098 \\
0 \\
0 \\
0\end{array}$ & $\begin{array}{l}.179 \\
.341 \\
.204 \\
.311\end{array}$ & $\begin{array}{l}0 \\
0 \\
0 \\
0\end{array}$ & $\begin{array}{r}.155 \\
<.001 \\
.811 \\
.340\end{array}$ & $\begin{array}{l}.019 \\
.003 \\
.012 \\
.017\end{array}$ & $\begin{array}{l}1.325 \\
1.384 \\
2.445 \\
1.839\end{array}$ & $\begin{array}{l}1.926 \\
1.729 \\
1.850 \\
1.932\end{array}$ & $\begin{array}{l}803 \\
21.6 \\
16.4 \\
54.6\end{array}$ \\
\hline
\end{tabular}


checked by calculating reconstructed streamflow as discharge per square mile for each station. A typical pattern existed for all stations, with streamflow during winter and spring far exceeding streamflow in summer and autumn. During years in which precipitation was above average in spring (1993, 1994, and 1996), the discharge during March through April consistently ranged from 5 to $7 \mathrm{ft}^{3} / \mathrm{s} / \mathrm{mi}^{2}$. During a dry year (1995), average monthly discharge for these months was 2 to $4 \mathrm{ft}^{3} / \mathrm{s} / \mathrm{mi}^{2}$. During August through September in all years studied, reconstructed streamflow typically fell to between 0.25 and $0.5 \mathrm{ft}^{3} / \mathrm{s} / \mathrm{mi}^{2}$.

Average observed- and reconstructedstreamflow values were calculated for "low-flow" and "peak-flow" months, which typically occur during late summer to early autumn and late winter to early spring, respectively. Low-flow and peakflow values were calculated by averaging streamflow values for August through September and March through April, respectively, for water years 1993-96 (table 6). Observed- and reconstructedstreamflow records during these periods were compared for gaging stations on the Passaic River (fig. 18). Average streamflow at each station is plotted in cubic feet per second as a function of drainage area. In general, as the drainage area increases, streamflow increases. The difference between observed and reconstructed streamflow for a station is represented by the vertical distance between the points. Changes in the slope of the hydrograph in downstream areas, for both observed and reconstructed streamflow, may be the result of inaccurate estimates of observed streamflow at stations 01389005 (Passaic River below Pompton River at Two Bridges, N.J.) and 01389880 (Passaic River at Route 46 at Elmwood Park, N.J.). Records from continuous-record stations such as 01389500 (Passaic River at Little Falls, N.J.) generally are much more accurate than estimated records.

Average streamflow at each station on the Passaic River as a function of drainage area, in cubic feet per second per square mile, is shown in figure 19. In general, values at each station would be expected to be relatively constant because streamflow is normalized by drainage area. Changes in the slope of the hydrograph in upstream areas for both observed and reconstructed stream- flow during August through September may be the result of the presence of wetlands between stations 01378690 and 01379580 , where evapotranspiration could be a significant factor.

Streamflow records for August through September and March through April also were compared for stations on the Ramapo, Pompton, and Lower Passaic Rivers (figs. 20 and 21). Results for stations on this stream reach (table 7) were similar to results for stations on the Passaic River. The three gaging stations on the Lower Passaic River are common to both reaches. Average reconstructed-streamflow values during August through September, in cubic feet per second per square mile, ranged from 0.4 at station 01379000 to 0.8 at stations 01378690,01381900 , and 01382000 ard from 3.7 at stations 01389500,01389580 , 01389500 , and 01389880 to 5.2 at station 01388910 during March through April.

Reconstructed-flow records for each station also were calculated in terms of cubic feet per second per square mile for each subwatershed--that is, runoff from all upstream subwatersheds was excluded. By comparing streamflow values by subwatershed, stations at which reconstructed streamflow was greater upstream than downstream were identified. This method also was useful for idertifying problems with ground-water and surfacewater withdrawal data and point-source-discharge data used to calculate reconstructed streamflow. Stations for which reconstructed-streamflow values were inconsistent with those for other staticns were identified, and the data used in the calculation were checked for discrepancies.

Reconstructed-streamflow values for several subwatersheds exceeded values that were expected on the basis of drainage-area-normalized calculations. Several factors could account for these high values, but the specific causes are unknown. Pcssible causes include poor estimates of observed streamflow, inaccurate or incomplete withdrawal or discharge data, and unknown factors. In several cases, reconstructed-streamflow values were negative, which represents a loss of storage in the watershed above that station. Negative values ropresent only a small percentage of the monthly reconstructed-streamflow values at stations just 

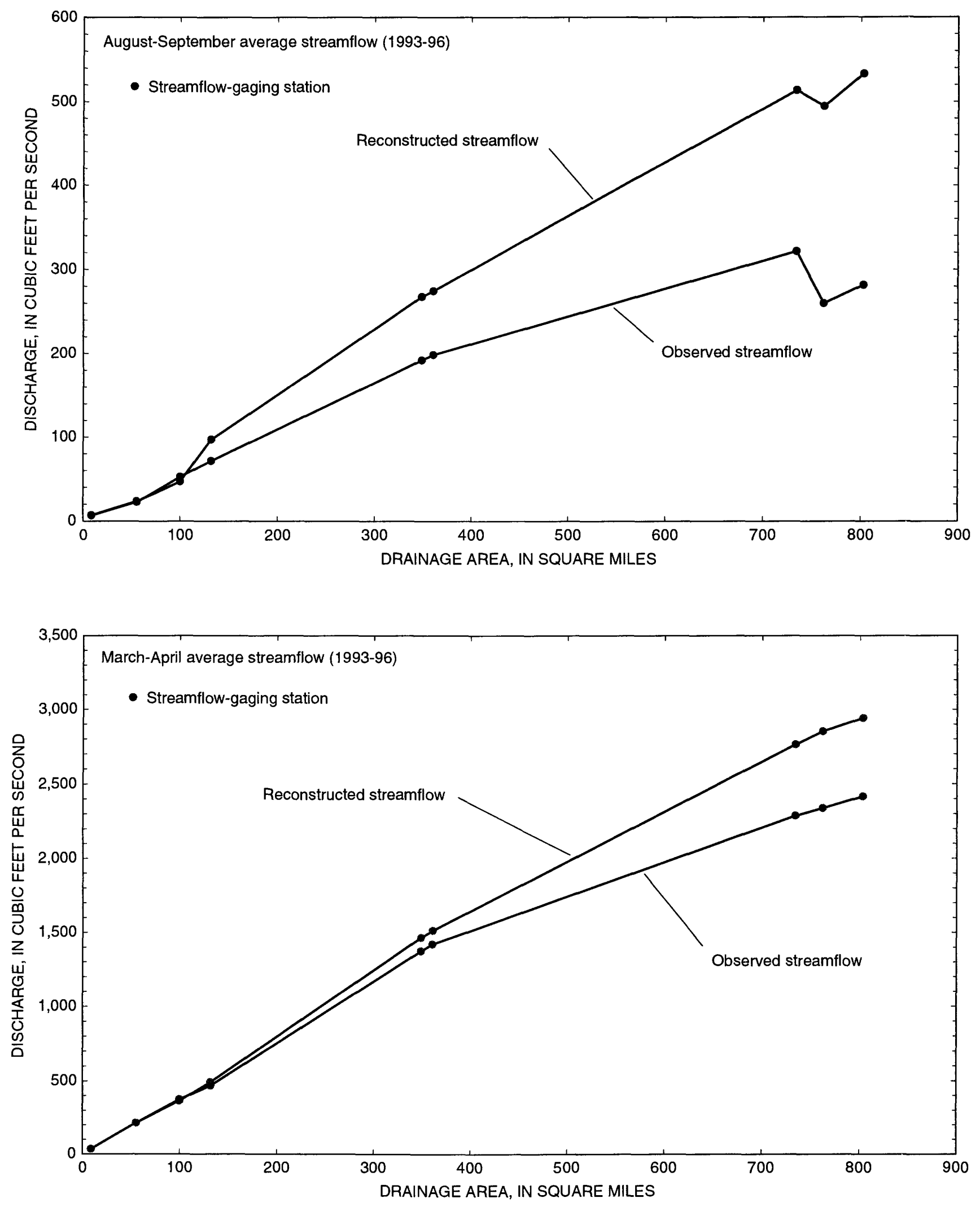

Figure 18. Average observed and reconstructed streamflow for August-September and March-April 1993-96 for streamflow-gaging stations on the Passaic River, New Jersey. 

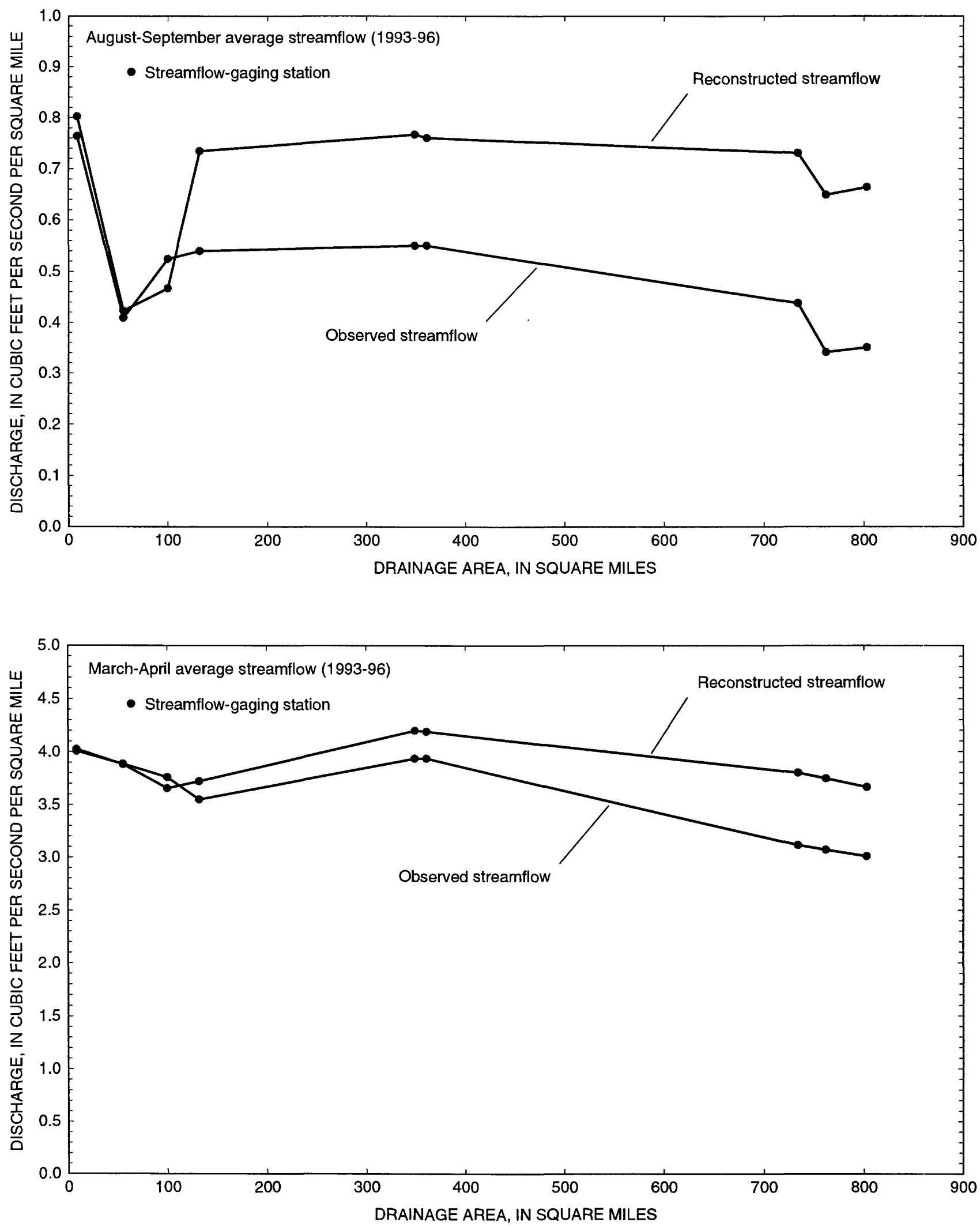

Figure 19. Average observed and reconstructed streamflow normalized by drainage area for AugustSeptember and March-April 1993-96 for streamflow-gaging stations on the Passaic River, New Jersey. 

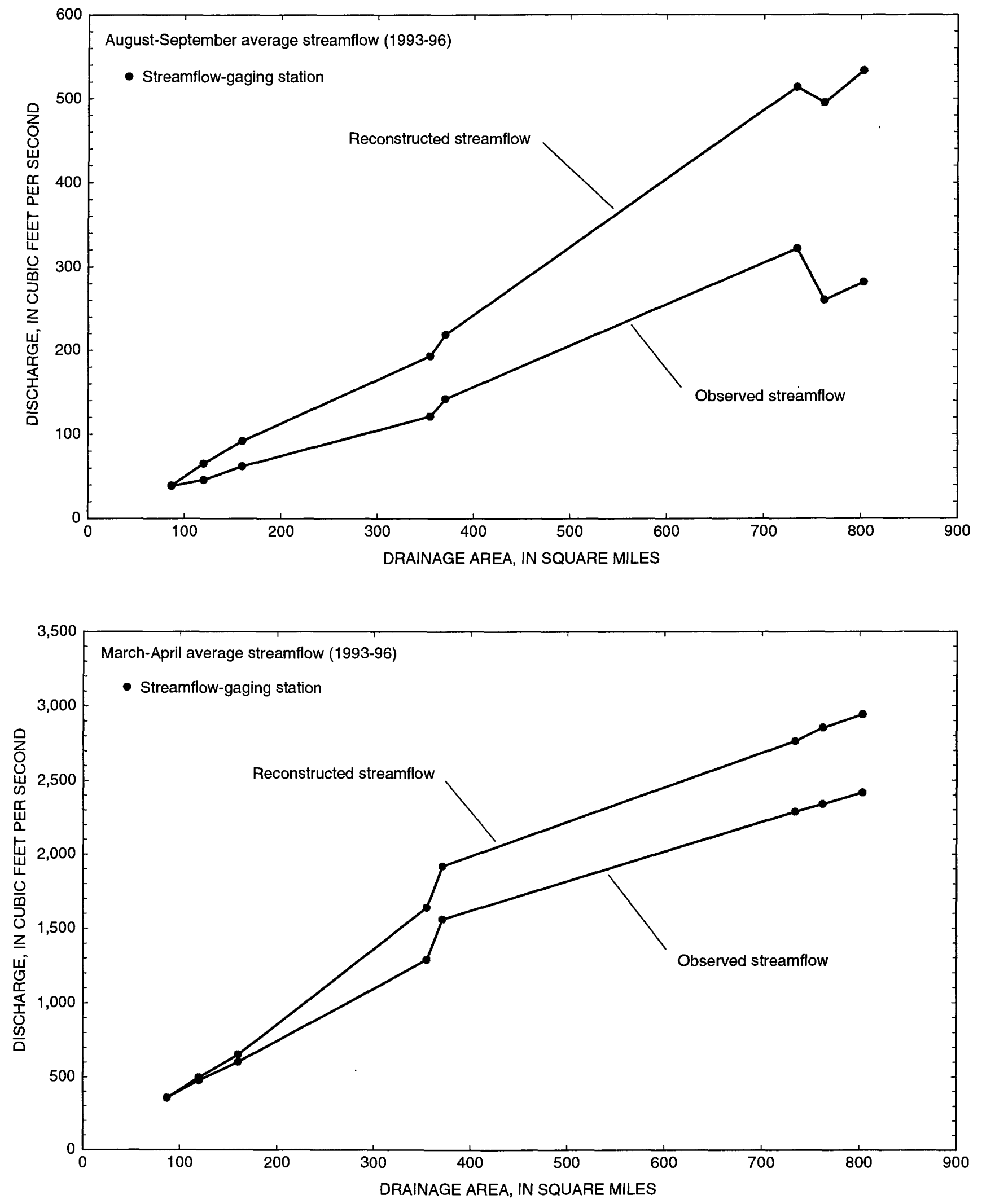

Figure 20. Average observed and reconstructed streamflow for August-September and March-April 1993-96 for streamflow-gaging stations on the Ramapo, Pompton, and Lower Passaic Rivers, New Jersey and New York. 

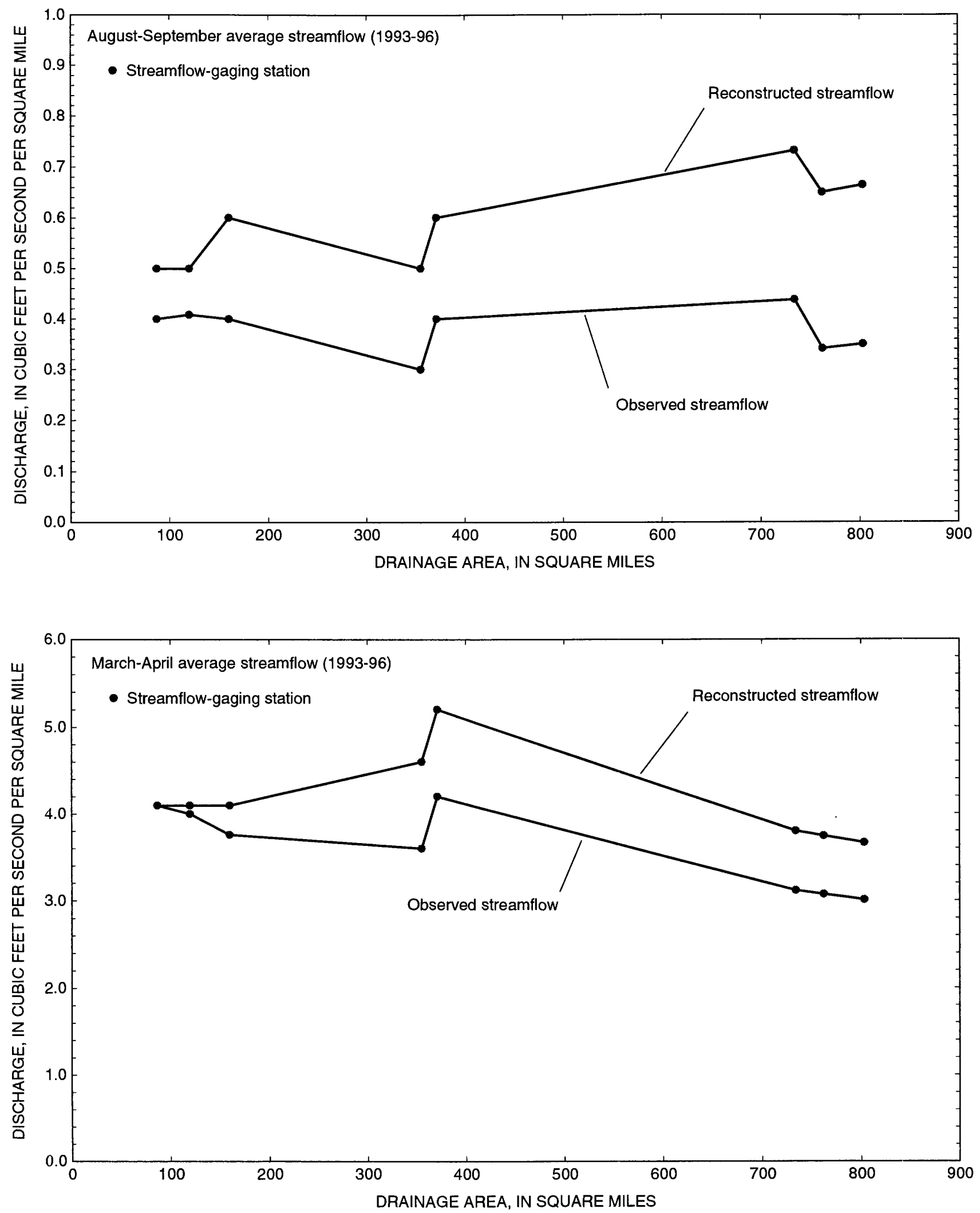

Figure 21. Average observed and reconstructed streamflow normalized by drainage area for AugustSeptember and March-April 1993-96 for streamflow-gaging stations on the Ramapo, Pompton, and Lower Passaic Rivers, New Jersey and New York. 
Table 6. Average observed and reconstructed streamflow for August through September and March through April during 1993-96 for streamflow-gaging stations on the Passaic River, New Jersey

\begin{tabular}{|c|c|c|c|c|c|c|c|c|}
\hline \multirow[b]{3}{*}{$\begin{array}{l}\text { U.S. Geological } \\
\text { Survey } \\
\text { streamflow- } \\
\text { gaging-station } \\
\text { number }\end{array}$} & \multicolumn{4}{|c|}{ Reconstructed streamflow } & \multicolumn{4}{|c|}{ Observed streamflow } \\
\hline & \multicolumn{2}{|c|}{ August-September } & \multicolumn{2}{|c|}{ March-April } & \multicolumn{2}{|c|}{ August-September } & \multicolumn{2}{|c|}{ March-A pril } \\
\hline & $\begin{array}{l}\text { Cubic feet } \\
\text { per second }\end{array}$ & $\begin{array}{l}\text { Cubic feet } \\
\text { per second } \\
\text { per square } \\
\text { mile } \\
\end{array}$ & $\begin{array}{l}\text { Cubic feet } \\
\text { per second }\end{array}$ & $\begin{array}{l}\text { Cubic feet } \\
\text { per second } \\
\text { per square } \\
\text { mile }\end{array}$ & $\begin{array}{l}\text { Cubic feet } \\
\text { per second }\end{array}$ & $\begin{array}{c}\text { Cubic feet } \\
\text { per second } \\
\text { per square } \\
\text { mile }\end{array}$ & $\begin{array}{l}\text { Cubic feet } \\
\text { per second }\end{array}$ & $\begin{array}{c}\text { Cubic feet } \\
\text { par second } \\
\text { Fer square } \\
\text { mile }\end{array}$ \\
\hline $\begin{array}{l}01378690 \\
01379000 \\
01379500 \\
01379580 \\
01381900\end{array}$ & $\begin{array}{r}7.1 \\
23.4 \\
46.7 \\
96.9 \\
268\end{array}$ & $\begin{array}{r}0.8 \\
.4 \\
.5 \\
.7 \\
.8\end{array}$ & $\begin{array}{c}35.5 \\
215 \\
365 \\
491 \\
1,470\end{array}$ & $\begin{array}{l}4.0 \\
3.9 \\
3.7 \\
3.7 \\
4.2\end{array}$ & $\begin{array}{r}6.7 \\
22.6 \\
52.5 \\
71.3 \\
192\end{array}$ & $\begin{array}{r}0.8 \\
.4 \\
.5 \\
.5 \\
.6\end{array}$ & $\begin{array}{c}35.4 \\
215 \\
376 \\
468 \\
1,370\end{array}$ & $\begin{array}{l}4.0 \\
3.9 \\
3.8 \\
3.5 \\
3.9\end{array}$ \\
\hline $\begin{array}{l}01382000 \\
01389005 \\
01389500 \\
01389880\end{array}$ & $\begin{array}{l}275 \\
514 \\
495 \\
533\end{array}$ & $\begin{array}{l}.8 \\
.7 \\
.6 \\
.7\end{array}$ & $\begin{array}{l}1,510 \\
2,760 \\
2,850 \\
2,940\end{array}$ & $\begin{array}{l}4.2 \\
3.8 \\
3.7 \\
3.7\end{array}$ & $\begin{array}{l}199 \\
321 \\
260 \\
282\end{array}$ & $\begin{array}{l}.6 \\
.4 \\
.3 \\
.4\end{array}$ & $\begin{array}{l}1,420 \\
2,290 \\
2,340 \\
2,420\end{array}$ & $\begin{array}{l}3.9 \\
3.1 \\
3.1 \\
3.0\end{array}$ \\
\hline
\end{tabular}

Table 7. Average observed and reconstructed streamflow for August through September and March through April during 1993-96 for streamflow-gaging stations on the Ramapo, Pompton, and Lower Passaic Fivers, New Jersey and New York

\begin{tabular}{|c|c|c|c|c|c|c|c|c|}
\hline \multirow[b]{3}{*}{$\begin{array}{l}\text { U.S. Geological } \\
\text { Survey } \\
\text { streamflow- } \\
\text { gaging-station } \\
\text { number } \\
\end{array}$} & \multicolumn{4}{|c|}{ Reconstructed streamflow } & \multicolumn{4}{|c|}{ Observed streamflow } \\
\hline & \multicolumn{2}{|c|}{ August-September } & \multicolumn{2}{|c|}{ March-April } & \multicolumn{2}{|c|}{ August-September } & \multicolumn{2}{|c|}{ March-Afril } \\
\hline & $\begin{array}{l}\text { Cubic feet } \\
\text { per second }\end{array}$ & $\begin{array}{c}\text { Cubic feet } \\
\text { per second } \\
\text { per square } \\
\text { mile }\end{array}$ & $\begin{array}{l}\text { Cubic feet } \\
\text { per second }\end{array}$ & $\begin{array}{c}\text { Cubic feet } \\
\text { per second } \\
\text { per square } \\
\text { mile }\end{array}$ & $\begin{array}{l}\text { Cubic feet } \\
\text { per second }\end{array}$ & $\begin{array}{c}\text { Cubic feet } \\
\text { per second } \\
\text { per square } \\
\text { mile }\end{array}$ & $\begin{array}{l}\text { Cubic feet } \\
\text { per second }\end{array}$ & $\begin{array}{c}\text { Cubic feet } \\
\text { per second } \\
\text { per square } \\
\text { mile }\end{array}$ \\
\hline 01387400 & 39.2 & 0.5 & 354 & 4.1 & 38.6 & 0.4 & 357 & 4.1 \\
\hline 01387500 & 65.1 & .5 & 496 & $\begin{array}{l}4.1 \\
4.1\end{array}$ & 45.7 & .4 & 475 & 4.0 \\
\hline 01388000 & 91.8 & .6 & 651 & 4.1 & 62.0 & .4 & 601 & 3.8 \\
\hline 01388500 & 193 & .5 & 1,640 & 4.6 & 121 & .3 & 1,290 & 3.6 \\
\hline 01388910 & 219 & .6 & 1,920 & 5.2 & 142 & .4 & 1,560 & 4.2 \\
\hline 01389005 & 514 & .7 & 2,760 & 3.8 & 321 & .4 & 2,290 & 3.1 \\
\hline 01389500 & 495 & .6 & 2,850 & 3.7 & 260 & .3 & 2,340 & 3.1 \\
\hline 01389880 & 533 & .7 & 2,940 & 3.7 & 282 & .4 & 2,420 & 3.0 \\
\hline
\end{tabular}


downstream from some of the major water-supply reservoirs in the study area and occurred during extended periods of drought in 1993 and 1995. The negative values may be a result of inaccuratereservoir-storage and withdrawal data or unaccountedfor losses from the reservoirs, such as evaporation and leakage.

At the Wanaque Reservoir, the maximum average monthly withdrawal during 1995 was 175 $\mathrm{Mgal} / \mathrm{d}\left(270 \mathrm{ft}^{3} / \mathrm{s}\right)$ and the maximum monthly change in storage was $206 \mathrm{Mgal} / \mathrm{d}\left(318 \mathrm{ft}^{3} / \mathrm{s}\right)$. An error of 5 percent in these data could result in an error of $30 \mathrm{ft}^{3} / \mathrm{s}$ in the reconstructed-streamflow value at the gaging station downstream from the reservoir and could cause values to be negative during low-flow months. Alternatively, if drought conditions are severe, evaporation losses from reservoirs could be greater than inflow, resulting in a loss of storage and negative reconstructed-streamflow values.

Because many large and small lakes and reservoirs are present throughout the study area (table 3 ), evaporation from open water surfaces affects observed streamflow at all gaging stations. The two primary factors that affect evaporation from an open water surface are the supply of energy to provide the heat of vaporization and the ability to transport water vapor away from the evaporative surface (Chow and others, 1988). These factors include energy primarily in the form of solar radiation, wind velocity over the surface, air temperature and pressure, and the specific-humidity gradient. Along with these factors, the volume of evaporation from a given area, such as a river basin, depends on the area of the open water surface within that basin. Evaporation from land and plant surfaces, as well as transpiration through vegetation, also can be substantial depending on the availability of moisture at the evaporative surface.

\section{Mass Balance}

A detailed water balance for the Passaic and Hackensack River Basins using reconstructed streamflow cannot be calculated because not all gains and losses to the basins are accounted for. An approximate balance can be calculated if some assumptions are made, however, and several com- ponents of the reconstructed-streamflow equation can be evaluated to determine the accuracy ant completeness of the withdrawal and discharge data.

Streamflow in a natural system defined in simple terms is equal to precipitation minus evapotranspiration minus changes in ground-water $₹$ nd surface-water storage (see equation on p. 32). If it is assumed that ground-water and surface-wat storage did not change significantly over the 4-year study period, the equation can be simplified tc discharge $=$ precipitation - evapotranspiration. $\mathrm{Tl}$. average annual precipitation in northern New Jersey is 48 in. The average annual actual evapot "anspiration is about 24 in. (Thornthwaite and others, 1958). By using these numbers, natural streamflow was calculated for the three most downstream stations in the study area-- $200 \mathrm{ft}^{3} / \mathrm{s}$ at Hackensack River at New Milford, N.J.; $96.5 \mathrm{ft}^{3} / \mathrm{s}$ at Saddle River at Lodi, N.J.; and 1,420 $\mathrm{ft}^{3} / \mathrm{s}$ at Passaic Piver at Route 46 at Elmwood Park, N.J. Average reconstructed-streamflow values for these stations curing the 4-year study period were 199,105 , and $1,550 \mathrm{ft}^{3} / \mathrm{s}$, respectively. The differences between average reconstructed-flow values and estimated natural- flow values calculated by using the simplified water-balance equation were all less than 10 percent.

In theory, the sum of all ground-water and surface-water withdrawals and interbasin trancfers equals the sum of the discharges and any consumptive losses from the basin. If all withdrawals vere returned to streamflow as point-source discharges, reconstructed streamflow would be about equal to observed streamflow minus consumptive water loss. In the Passaic and Hackensack River Basins, several high-volume treatment facilities discharge outside the study area--below the most downst "eam stations in the study area, or to Newark or Ne'v York Bays. Consequently, a water balance for the study area would be expected to show a large deficit. These treatment facilities include Passaic Valley Sewage Commission, with an average discharge of $226 \mathrm{Mgal} / \mathrm{d}\left(350 \mathrm{ft}^{3} / \mathrm{s}\right)$; Essex Joint Meeting Sewage-Treatment Plant, $65 \mathrm{Mgal} / \mathrm{d}$ (101 $\mathrm{ft}^{3} / \mathrm{s}$ ); Bergen County Sewage-Treatment Plar ${ }^{*}, 62$ $\mathrm{Mgal} / \mathrm{d}\left(96 \mathrm{ft}^{3} / \mathrm{s}\right)$; and Jersey City Sewage-Treatment Plants, $41 \mathrm{Mgal} / \mathrm{d}\left(63 \mathrm{ft}^{3} / \mathrm{s}\right)$. Other, smaller facilities that discharge outside the study area 
account for about $36 \mathrm{Mgal} / \mathrm{d}\left(56 \mathrm{ft}^{3} / \mathrm{s}\right)$ discharged from the basin (Zripko and Hasan, 1994). Most of this water comes from the major reservoirs in the study area. The sum of discharges to areas outside the study area is $430 \mathrm{Mgal} / \mathrm{d}\left(665 \mathrm{ft}^{3} / \mathrm{s}\right)$. The average sum of point-source discharges within the study area during $1993-96$ is $95.7 \mathrm{Mgal} / \mathrm{d}$ $\left(148 \mathrm{ft}^{3} / \mathrm{s}\right)$, for a total discharge of $525 \mathrm{Mgal} / \mathrm{d}$ $\left(813 \mathrm{ft}^{3} / \mathrm{s}\right)$.

Average ground-water and surface-water withdrawals within the study area during 1993-96 were $112 \mathrm{Mgal} / \mathrm{d}\left(173 \mathrm{ft}^{3} / \mathrm{s}\right)$ and $381 \mathrm{Mgal} / \mathrm{d}$ (590 $\left.\mathrm{ft}^{3} / \mathrm{s}\right)$, respectively, and interbasin transfers were estimated to be about $9.7 \mathrm{Mgal} / \mathrm{d}\left(15 \mathrm{ft}^{3} / \mathrm{s}\right)$ (New Jersey Department of Environmental Protection, 1992), for a total withdrawal of $503 \mathrm{Mgal} / \mathrm{d}(778$ $\mathrm{ft}^{3} / \mathrm{s}$ ). If consumptive loss is assumed to be about 8 percent (Solley and others, 1998), total discharge would be about $463 \mathrm{Mgal} / \mathrm{d}\left(716 \mathrm{ft}^{3} / \mathrm{s}\right)$, on the basis of total withdrawals. Most of the difference between the calculated and actual discharge values could be the result of infiltration and inflow, discharge from combined sewer systems in urban areas, and discharge from facilities that treat stormwater runoff. These types of discharge are not accounted for in the withdrawal values.

\section{SUMMARY AND CONCLUSIONS}

Drought conditions in northern New Jersey during several periods in 1980-95 and the imposition of drought warnings and water-use restrictions have shown the vulnerability of the water resources and the problems of water management. The U.S. Geological Survey, in cooperation with the New Jersey Department of Environmental Protection, conducted an investigation to (1) reconstruct monthly streamflow records for 34 streamflow stations in the Passaic and Hackensack River Basins in New York and New Jersey for water years 199396 , and (2) reconstruct daily streamflow records for the same 34 streamflow stations for the drought period May 1, 1995, through October 31, 1995. To effectively manage water resources during periods of drought, knowledge of the historical values of natural streamflow and information about the effects of human activities on streamflow are necessary. Reconstructed-streamflow records are an estimate of natural streamflow based on observed- streamflow records that takes into considerstion known surface- and ground-water withdrawals, discharges to surface-water bodies, changes in storage in water-supply reservoirs, transfers of water into, out of, or within the basin, and other factors, but does not attempt to include all human effects, many of which are unknown or not easily q'iantified. Reconstructed-streamflow records can be used by water managers as input to models that can be used to simulate streamflow under alternative conditions. Results of these simulations can be used to assess whether drought warnings ant emergencies are warranted and to evaluate water-supply options during periods of drought. The availability of reconstructed-streamflow records will allow evaluation of present or proposed water-supsly options under historical drought conditions with present infrastructure and water use. This study continues the work of previous investigations in which reconstructed-streamflow records for streamflow stations in the Passaic River Basin were developed for the period from October 1 , 1919, through September 30, 1993.

The Passaic and Hackensack River Ba sins lie in the northeastern part of New Jersey and the southeastern part of New York State, in the Piedmont and New England (Highlands) Physiographic Provinces. In 1995, the population of the Hackensack-Passaic HUC was estimated to be 2.54 million. About 94 percent of the total populaticn was served by public suppliers; the balance of the population supplied their own water from wells. About 1.6 million people received publicly supplie $f$ water from water-supply reservoirs, and about 800,000 received publicly supplied water from wells

This report describes the sources of ol rerved monthly and daily streamflow and other hyd "ologic data used to reconstruct streamflow records and methods used to estimate missing values. Monthly and daily data were collected from government agencies as well as directly from public and private water suppliers and wastewater-treatment fecrilities and other sources. Monthly and daily data from 87 surface-water-withdrawal sites, about 840 v'ells, 265 point-source-discharge facilities and 368 facility outfall pipes, and 15 reservoirs were included in the calculation of reconstructed streamflow. The report also describes the method used to recon- 
struct streamflow records at each streamflow-gaging station. The daily data set was developed as a test to determine whether daily streamflow records could be reconstructed from currently available data. Missing data were estimated by using various methods developed for this and other studies.

Average annual precipitation in the Northern division of New Jersey during 1961-90 was 48 in. Precipitation in the Northern division during 1993 and 1995 was below the average annual (1961-90) precipitation of 48 in. by 3 in. in 1993 and 13 in. in 1995, for annual precipitation values of $45 \mathrm{in}$. and 35 in., respectively. Precipitation during 1994 and 1996 was above the average annual precipitation by 5 in. in 1994 and 12 in. in 1996, for annual precipitation values of 53 in. and 60 in., respectively.

Continuous streamflow records were available for the entire study period (October 1, 1992, through September 30, 1996) for 24 of the 34 stations included in this study. Streamflow records for the remaining 10 stations were estimated by one or a combination of the following methods: (1) partial record retrieved from the ADAPS data base, (2) ESTWAT, a USGS computer program, (3) Maintenance of Variance Extension, Type 1 (MOVE1), and (4) drainage-area ratio.

Discharge data from 17 high-volume municipal treatment facilities in the study area were analyzed to verify the correlation between pointsource discharges from treatment facilities and streamflow. The monthly discharge data were correlated with streamflow at gaging stations above and below the point of discharge. Most of the discharges from treatment facilities were strongly correlated with streamflow. Daily reconstructedstreamflow values were not corrected for infiltration and inflow because of below-average precipitation during the study period.

Water from the upper reaches of both the Passaic and Hackensack River Basins is exported to urban centers in the eastern and southeastern part of the study area near New York City or out of the study area. A net loss of water from these basins is primarily the result of withdrawals from the basins that are returned to surface-water bodies as discharges outside the basins. At the three most downstream stations in the study area, Hackensack River at New Milford, Passaic River at Route 4.6 at Elmwood Park, and Saddle River at Lodi, the differences between reconstructed and observed streamflow averaged over the 4-year study perind were 149,483 , and $5 \mathrm{ft}^{3} / \mathrm{s}$, respectively. The largest withdrawals of surface water account for most of the differences between reconstructed and observed streamflow. At Hackensack River at 1 'ew Milford, N.J., surface-water withdrawals averaged $101 \mathrm{Mgal} / \mathrm{d}\left(156 \mathrm{ft}^{3} / \mathrm{s}\right)$. At Wanaque River (a tributary to the Passaic River) at Wanaque, N.J., surface-water withdrawals from within the subwatershed averaged $129 \mathrm{Mgal} / \mathrm{d}\left(200 \mathrm{ft}^{3} / \mathrm{s}\right)$. In the Saddle River Basin, ground-water and surfacewater withdrawals are nearly equal to discharg's within the subwatershed; therefore, the difference between reconstructed and observed streamflo'v is small.

Reconstructed streamflow was less than observed streamflow in only a few instances, in subwatersheds with high-volume point-source discharges from municipal treatment facilities that receive water that originates from sources outside the subwatershed and little or no ground- or surface-water withdrawals within the subwatershed. The average difference between reconstructed and observed streamflow was $-9.8 \mathrm{ft}^{3} / \mathrm{s}$ at HoHoKus Brook at Ho-Ho-Kus, N.J., and $-7.5 \mathrm{ft}^{3} / \mathrm{s}$ at Passaic River near Chatham, N.J.

Natural-streamflow estimates were calcrlated for the three most downstream stations ir the study area by using a simplified water-balance equation. These estimates were $200 \mathrm{ft}^{3} / \mathrm{s}$ at Hackensack River at New Milford, N.J.; $96.5 \mathrm{ft}^{3} / \mathrm{s}$ at Saddle River at Lodi, N.J.; and $1,420 \mathrm{ft}^{3} / \mathrm{s}$ at Prssaic River at Route 46 at Elmwood Park, N.J. Average reconstructed-streamflow values for these stations during the 4-year study period were 199 , 105 , and $1,546 \mathrm{ft}^{3} / \mathrm{s}$, respectively. Differences between average reconstructed-flow values and average estimated natural-flow values at these three stations were less than 10 percent. 


\section{REFERENCES CITED}

Bauersfeld, W.R., Moshinsky, E.W., and Gurney, C.E., 1994, Water-resources data, New Jersey, water year 1993, v. 1--Surface-water data: U.S. Geological Survey Water-Data Report N.J.-93-1, 503 p.

Bauersfeld, W.R., Moshinsky, E.W., and Gurney, C.E., 1995, Water-resources data, New Jersey, water year 1994, v. 1--Surface-water data: U.S. Geological Survey Water-Data Report N.J.-94-1,534 p.

Buxton, D.E., Hunchak-Kariouk, Kathryn, and Hickman, R.E., 1998, Relations of surfacewater quality to streamflow in the Hackensack, Passaic, Elizabeth, and Rahway River Basins, New Jersey, water years 1976-93: U.S. Geological Survey Water-Resources Investigations Report 98-4049, 102 p.

Carswell, L.D., and Rooney, J.G., 1976, Summary of geology and ground-water resources of Passaic County, New Jersey: U.S. Geological Survey Water-Resources Investigations Report 76-75, 47 p.

Chow, V.T., Maidment, D.R., and Mays, L.W., 1988, Applied hydrology: New York, McGrawHill, Inc., 572 p.

Czarnik, T.S., and Kozinski, Jane, 1994, Groundwater quality in the central part of the Passaic River Basin, northeastern New Jersey, 1959-88: U.S. Geological Survey WaterResources Investigations Report 92-4083, $66 \mathrm{p}$.

Drake, A.A., Jr., Volkert, R.A., Monteverde, D.H., Herman, G.C., Houghton, H.F., Parker, R.A., and Dalton, R.F., 1996, Bedrock geologic map of northern New Jersey: U.S. Geological Survey Miscellaneous Investigations Series Map I-2540-A, scale 1:100,000.

Dunne, Paul, and Tasker, Gary, 1996, Computer model of the Raritan River Basin water-supply system in central New Jersey: U.S. Geological Survey Open-File Report 96-360, $62 \mathrm{p}$.

Freeze, R.A., and Cherry, J.A., 1979, Groundwater: Englewood Cliffs, N.J., Prentice-Hall, 604 p.
Gordon, A.D., 1993, Hydrogeology of, and sinulated ground-water flow in, the valley-fill aquifers of the upper Rockaway River Basin, Morris County, New Jersey: U.S. Geological Survey Water-Resources Investigations Report 93-4145, 74 p.

Heath, R.C., 1983, Basic ground-water hydro'ngy: U.S. Geological Survey Water-Supply Paper 2220, $84 \mathrm{p}$.

Herman, G. C., and Mitchell, J. P., 1991, Bedrock geologic map of the Green Pond Mountain region from Dover to Greenwood Lake region, New Jersey: New Jersey Geolorical Survey Map Series 91-2, 3 pl.

Hickman, R.E., 1997, Water quality on days $c^{f}$ diversion and days of no diversion, Pompton and Passaic Rivers, New Jersey, 197-95: U. S. Geological Survey Open-File Report 97-573, $94 \mathrm{p}$.

Hickman, R.E., 1999, Trends in water quality of New Jersey streams, water years 1986-95: U.S. Geological Survey Water-Resources Investigations Report 98-4204, 174 p.

Hill, M. C., Lennon, G. P., Brown, G. A., Hebson, C. S., and Rheaume, S. J., 1992, Geohydrc'ogy of, and simulation of ground-water flew in, the valley-fill deposits in the Ramapo River Valley, New Jersey: U. S. Geological Survey Water-Resources Investigations Report 90-4151, $92 \mathrm{p}$.

Hirsch, R.M., 1982, A comparison of four streamflow record extension techniques: Water Resources Research, v. 18, no. 4, p. 10811088.

Hoffman, J.L., and Quinlan, John, 1994, Groundwater withdrawals and water-level data for the Central Passaic River Basin, New Jersey, 1898-1990: New Jersey Geological Surrey Report GSR 34, 78 p.

Jenkins, C.T., 1968, Computation of rate and volume of stream depletion by wells: U.S Geological Survey Techniques of WaterResources Investigations, book 4, chap. D1, $17 \mathrm{p}$. 


\section{REFERENCES CITED--Continued}

Lewis-Brown, J.C., and Jacobsen, Eric, 1995, Hydrogeology and ground-water flow, fractured Mesozoic structural-basin rocks, Stony Brook, Beden Brook, and Jacobs Creek drainage basins, west-central New Jersey: U.S. Geological Survey Water-Resources Investigations Report 94-4147, 83 p.

Lyttle, P. T. and Epstein, J. B., 1987, Geologic map of the Newark $1^{0} \times 2^{0}$ Quadrangle, New Jersey, Pennsylvania and New York: U. S. Geological Survey Miscellaneous Investigations Series Map I-1715, scale 1:250,000.

National Climatic Data Center, 1993, Climatological data annual summary, New Jersey, 1992: Asheville, N.C., National Oceanic and Atmospheric Administration, v. 97, no. 13, $22 \mathrm{p}$.

1994, Climatological data annual summary, New Jersey, 1993: Asheville, N.C., National Oceanic and Atmospheric Administration, v. 98, no. 13,14 p.

1995, Climatological data annual summary, New Jersey, 1994: Asheville, N.C., National Oceanic and Atmospheric Administration, v. 99, no. 13,12 p.

1996, Climatological data annual summary, New Jersey, 1995: Asheville, N.C., National Oceanic and Atmospheric Administration, v. 100, no. 13,11 p.

1997, Climatological data annual summary, New Jersey, 1996: Asheville, N.C., National Oceanic and Atmospheric Administration, v. 101 , no. 13,12 p.

Nawyn, J.P., 1997, Water use in Camden County, New Jersey, 1991: U.S. Geological Survey Open-File Report 97-12, 39 p.

Nawyn, J.P., 1998, Withdrawals of ground water and surface water in New Jersey, 1991-92: U.S. Geological Survey Open-File Report 98282, $57 \mathrm{p}$.
New Jersey Department of Environmental Protection, 1974, Land oriented reference data system: Trenton, N.J., New Jersey Department of Environmental Protection Bulletin 74, $151 \mathrm{p}$.

New Jersey Department of Environmental Protection, 1992, New Jersey statewide water supply master plan, task 2 report--Water supply baseline data development and analyses: Prepared by CH2M HILL, Metcalf \& Eddy, Inc., and New Jersey First, Inc., Novem ber $1992,326 \mathrm{p}$.

Nicholson, R.S., McAuley, S.D., Barringer, J.L., and Gordon, A.D., 1996, Hydrogeology of, and ground-water flow in, a valley-fill and carbonate-rock aquifer system near Long Valley in the New Jersey Highlands: U.S. Geo'ngical Survey Water-Resources Investigations Report 93-4157, 159 p., 3 pl.

Nicholson, R.S., and Watt, M.K., 1998, Simulation of ground-water-flow patterns and areas contributing recharge to streams and wratersupply wells in a valley-fill and carbon aterock aquifer system, southwestern Morris County, New Jersey: U.S. Geological Survey Water-Resources Investigations Report 97-4216, $40 \mathrm{p}$.

Price, Curtis V., and Schaefer, Frederick L., 19?5, Estimated loads of selected constituents from permitted and nonpermitted sources at selected surface-water-quality stations in the Musconetcong, Rockaway, and Whippany River Basins, New Jersey, 1985-90: U.S. Geological Survey Water-Resources Investigations Report 95-4040, 28 p.

Principi, V.C., 1991, The State of New Jersey 1991 well permit data report: Trenton, N.J., I lew Jersey Department of Environmental P "otection and Energy, $44 \mathrm{p}$.

Rantz, S.E., 1982, Measurement and computation of streamflow: Volume 1--Measuremen $t$ of stage and discharge: U.S. Geological Survey Water-Supply Paper 2175, 284 p.

Reed T.J., Centinaro, G.L., DeLuca, M.J., Hutchinson, J.T., and Scudder, J.J., 1997, Waterresources data, New Jersey, water year 1996, v. 1--Surface-water data: U.S. Geological Survey Water-Data Report N.J.-96-1, 562 p. 


\section{REFERENCES CITED--Continued}

Reed T.J., DeLuca, M.J., Centinaro, G.L., and Hutchinson, J.T., 1996, Water-resources data, New Jersey, water year 1995, v. 1--Surfacewater data: U.S. Geological Survey WaterData Report N.J.-95-1, 512 p.

Saarela, Helve, 1992, 1988 New Jersey water withdrawal report: Trenton, N.J., New Jersey Department of Environmental Protection and Energy, $42 \mathrm{p}$.

Schopp, R.D., and Bauersfeld, W.R., 1986, New Jersey surface-water resources, in Moody, D.W., Chase, E.B., and Aronson, D.A.,, compilers, National water summary 1985-Hydrologic events and surfacewater resources: U.S. Geological Survey Water-Supply Paper 2300, p. 335-340.

Seaber, P.R., Kapinos, F.P., and Knapp, G.L., 1987, Hydrologic unit maps: U.S. Geological Survey Water-Supply Paper 2294, 63 p.

Snavely, D.S., Harrison, E.Z., and Pike, H.C., 1990, New York water supply and use, in Carr, J.E., Chase, E.B., Paulson, R.W., and Moody, D.W., compilers, National water summary 1987--Hydrologic events and water supply and use: U.S. Geological Survey Water-Supply Paper 2350, p. 383-392.

Solley, W.B., Pierce, R.R., and Perlman, H.A., 1998, Estimated use of water in the United States in 1995: U.S. Geological Survey Circular $1200,71 \mathrm{p}$.

Stanford, S.D., Witte, R.W., and Harper, D.P., 1990, Hydrogeologic character and thickness of glacial sediments in New Jersey: Trenton, N.J., New Jersey Geological Survey OpenFile Map 3, scale 1:100,000.

Thornthwaite, C.W., Mather, J.R., and Carter, D.B., 1958, Three water balance maps of eastern North America: Resources for the Future, Inc., Washington, D.C., 47 p., 3 pl.

U.S. Bureau of the Census, 1994, 1994 County and city extra--Annual metro city and county data book: Washington, D.C., U.S. Government Printing Office, $1,043 \mathrm{p}$.
U.S. Environmental Protection Agency, 1985, Infiltration/Inflow, I/I analysis and projec certification: Washington, D.C., U.S.

Environmental Protection Agency, Office of Municipal Pollution Control, May 1985, 8 p.

U.S. Water Resources Council, 1978, The Nation's water resources: The second national water assessment by the Water Resources Council-Mid Atlantic Region (02): W'ashington, D.C., U.S. Water Resources Council, $188 \mathrm{p}$.

Vecchioli, John, and Miller, E.G., 1973, Water resources of the New Jersey part of the Ramapo River Basin: U.S. Geological Survey Water-Supply Paper 1974, 77 p.

Vermeule, C.C., 1894, Report on water-supply, water-power, the flow of streams and attendant phenomena: Trenton, N.J., Geological Survey of New Jersey, Final Report of the State Geologist, v. III, 352 p.

Voronin, L.M., and Rice, D.E., 1996, Hydroge and simulation of ground-water flow, Picatinny Arsenal and vicinity, Morris County, New Jersey: U.S. Geological Survey WaterResources Investigations Report 96-4061, $64 \mathrm{p}$.

Winter, C.W., Harvey, J.W., Franke, O.L., and Alley, W.M., 1998, Ground water and surface water--A single resource: U.S. Geological Survey Circular 1139, 79 p.

Zripko, P.N., and Hasan, Asghar, 1994, Depletive water use project for regional water res ource planning areas of New Jersey: Trenton, N.J., New Jersey Department of Environmental Protection, Office of Land and Water Planning, $149 \mathrm{p}$. 
APPENDIX 1. MONTHLY MEAN OBSERVED AND RECONSTRUCTED STREAMFLOW FROM OCTOBER 1992 THROUGH SEPTEMBER 1996 BY SUBWATERSHED FOR 34 STREAMFLOW-GAGING STATIONS IN THE PASSAIC AND HACKENSACK RIVER BASINS,

NEW JERSEY AND NEW YORK 

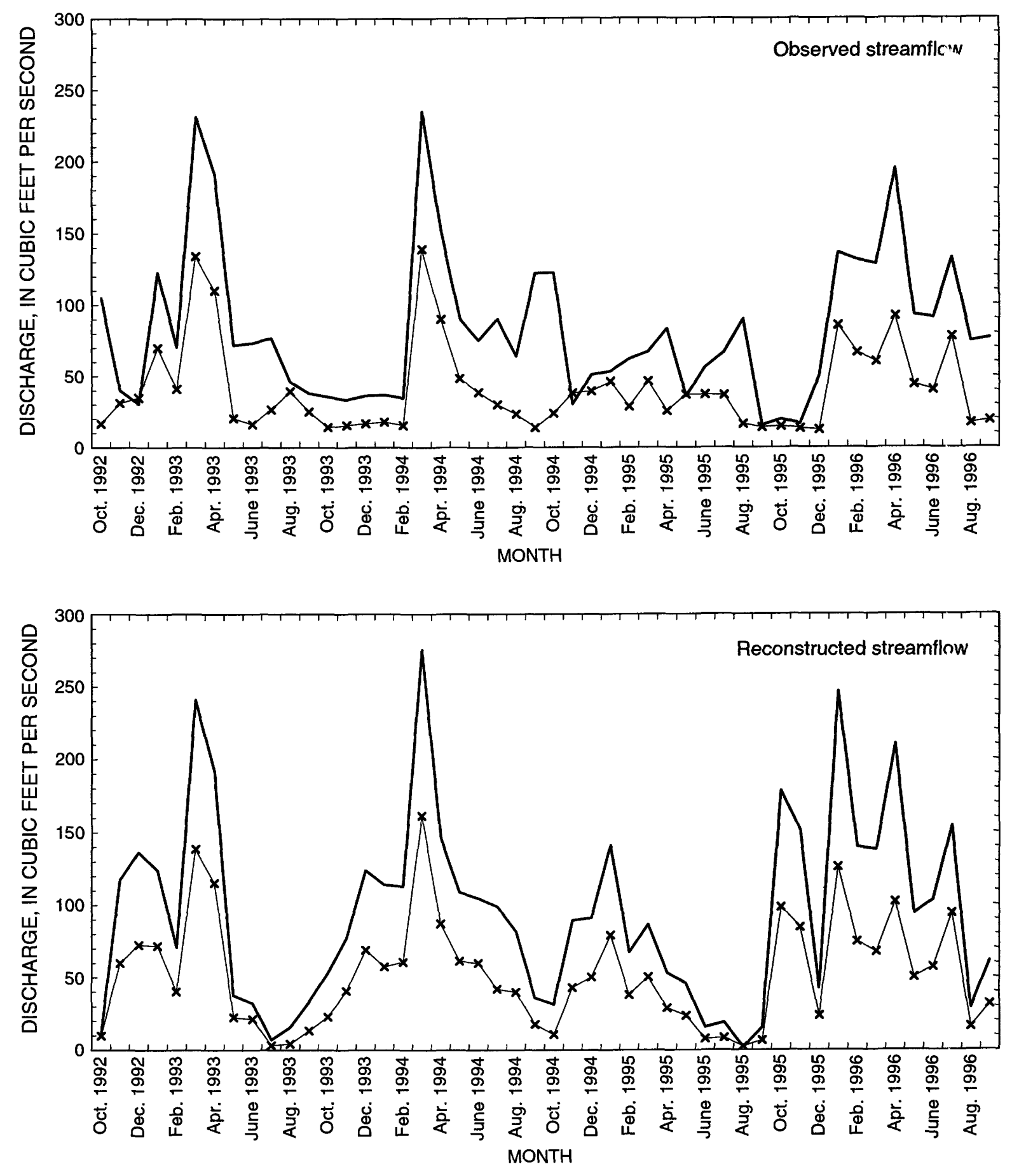

\section{EXPLANATION}

-01376800 Hackensack River at West Nyack, N.Y.

01377000 Hackensack River at Rivervale, N.J.

Figure 1-1a. Monthly mean observed and reconstructed streamflow for streamflow-gaging stations in the Hackensack River Basin, New Jersey and New York, October 1992-September 1996. 

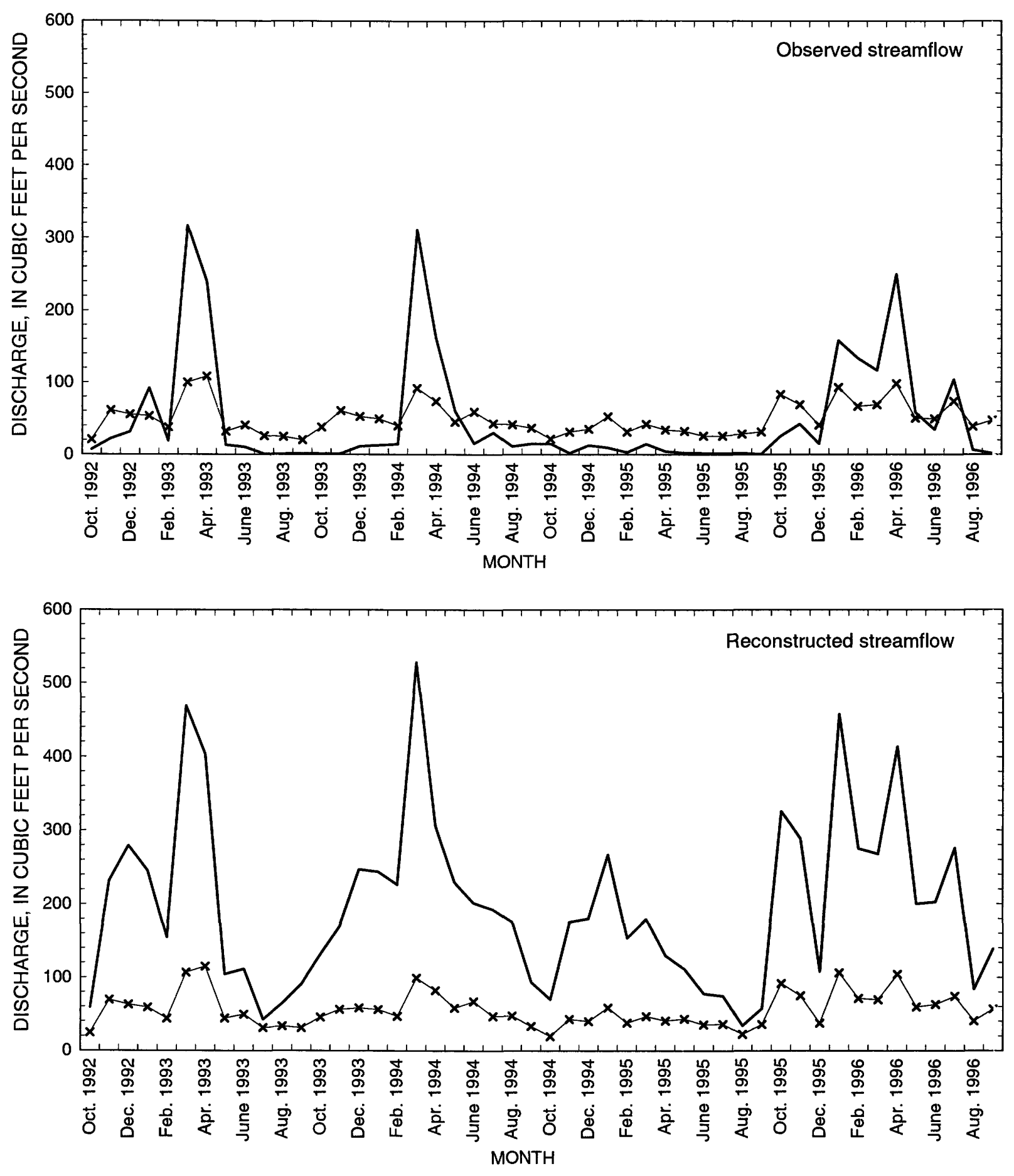

\section{EXPLANATION}

$\longrightarrow 01377500$ Pascack Brook at Westwood, N.J.

01378500 Hackensack River at New Milford, N.J.

Figure 1-1b. Monthly mean observed and reconstructed streamflow for streamflow-gaging stations ir the Hackensack River Basin, New Jersey and New York, October 1992-September 1996--Continued. 

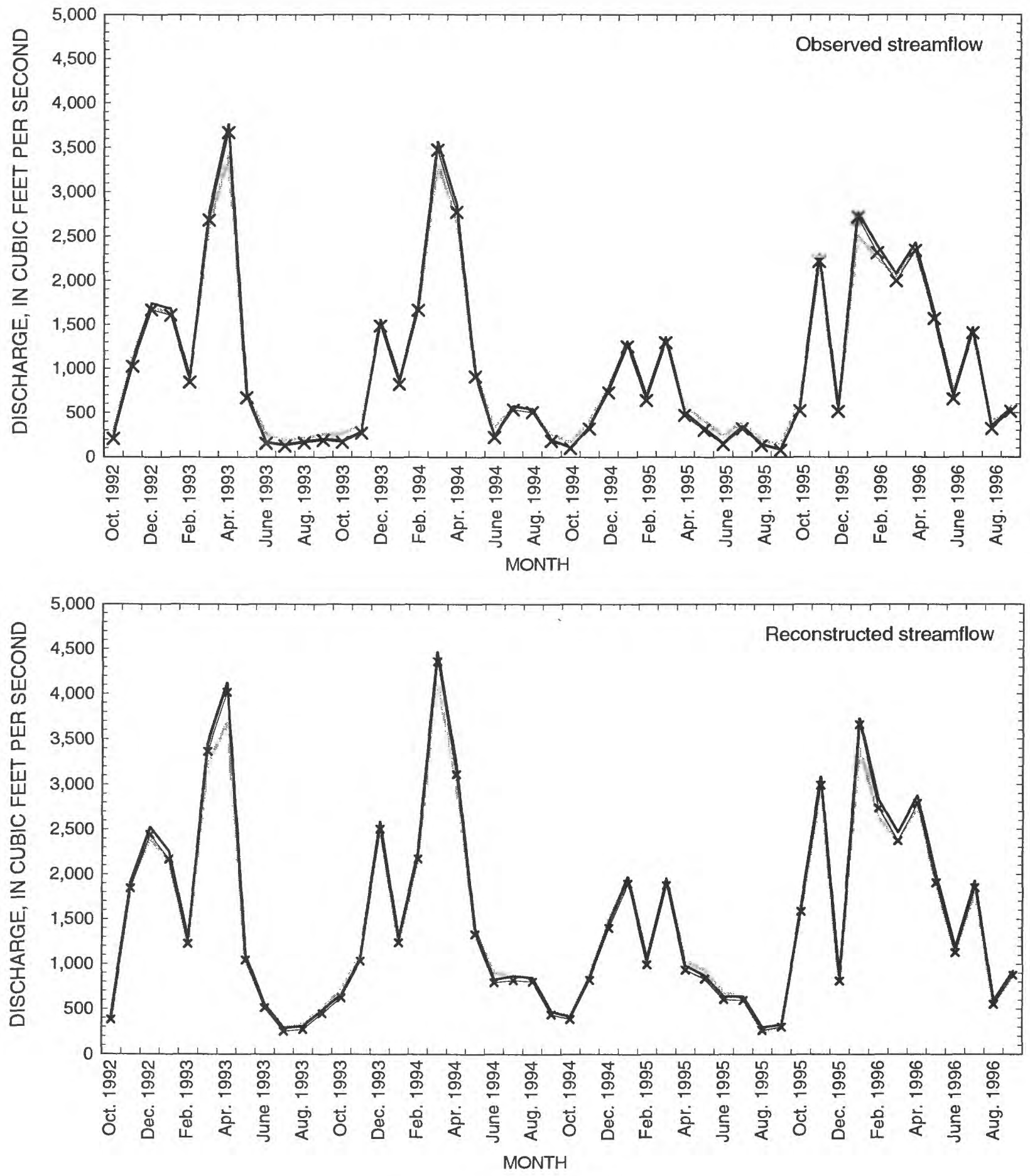

\section{EXPLANATION}

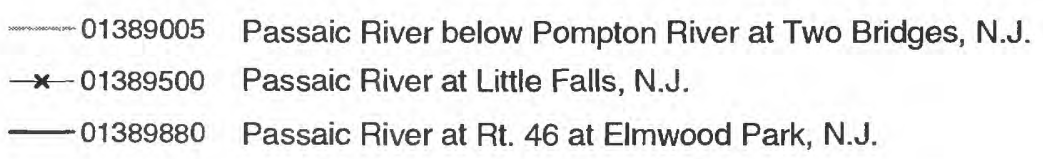

Figure 1-2. Monthly mean observed and reconstructed streamflow for streamflow-gaging stations in the Lower Passaic River Basin, New Jersey, October 1992-September 1996. 

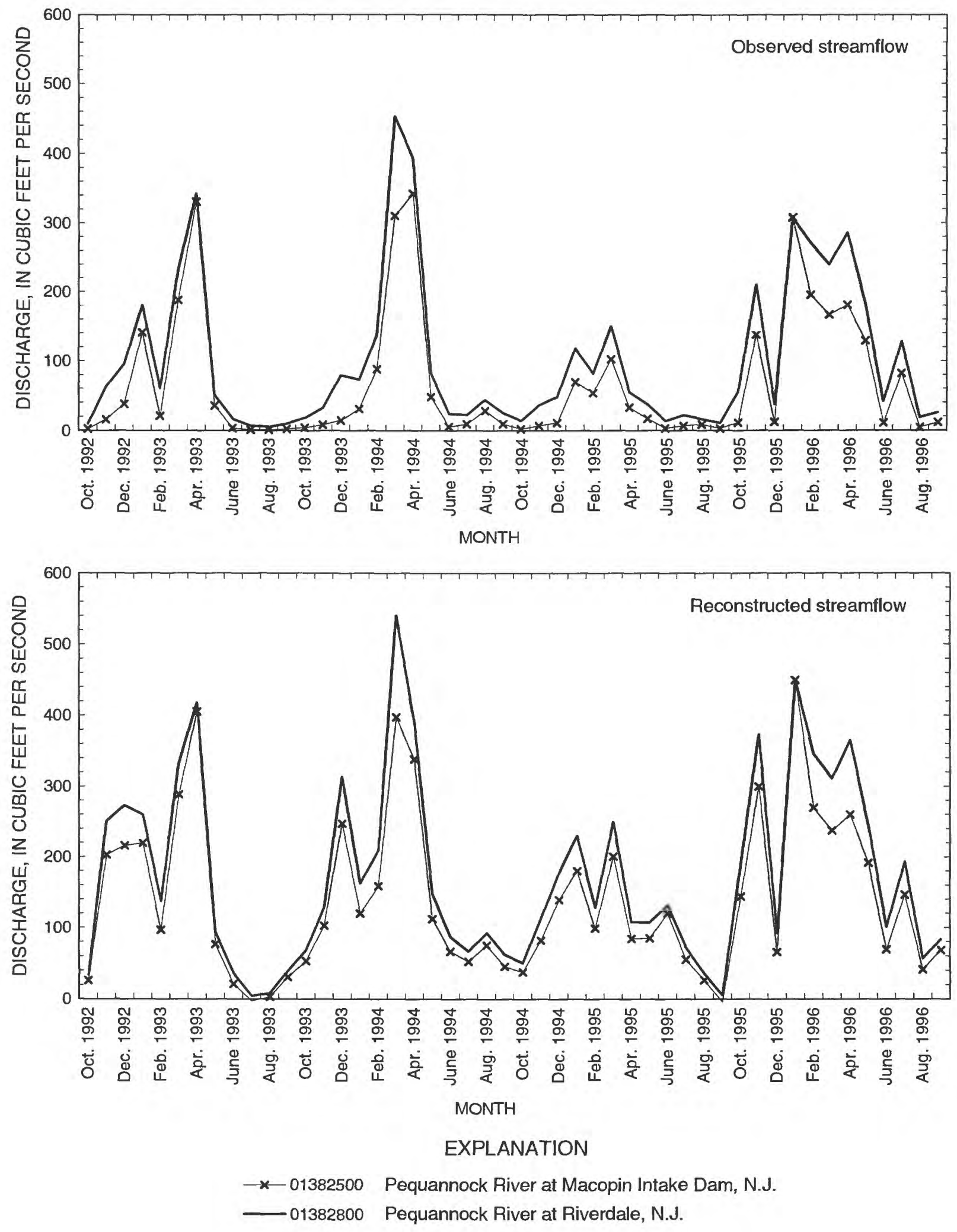

Figure 1-3. Monthly mean observed and reconstructed streamflow for streamflow-gaging stations in the Pequannock River Basin, New Jersey, October 1992-September 1996. 

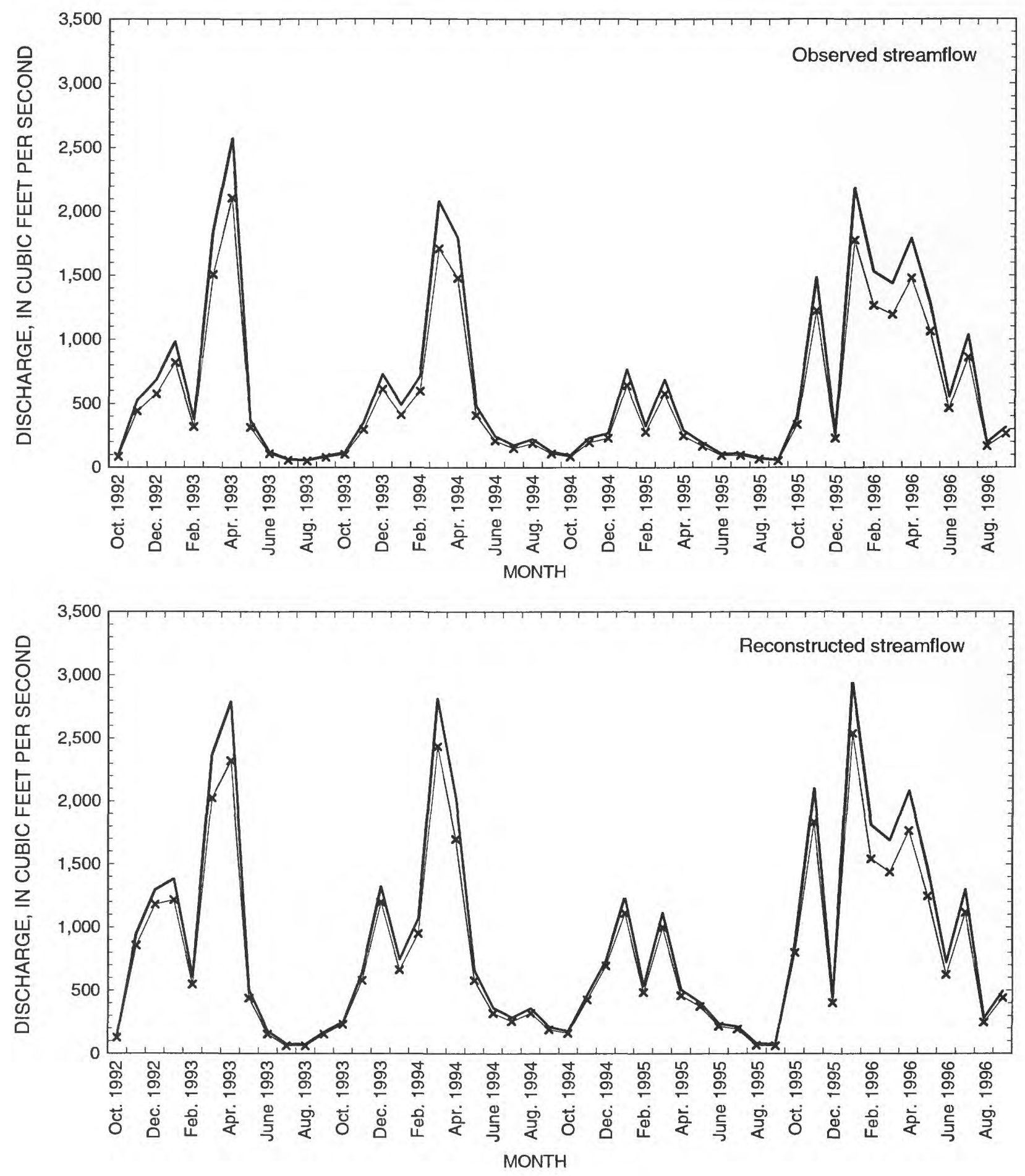

EXPLANATION

× 01388500 Pompton River at Pompton Plains, N.J.

01388910 Pompton River at Mountain View, N.J.

Figure 1-4. Monthly mean observed and reconstructed streamflow for streamflow-gaging stations in the Pompton River Basin, New Jersey, October 1992-September 1996. 

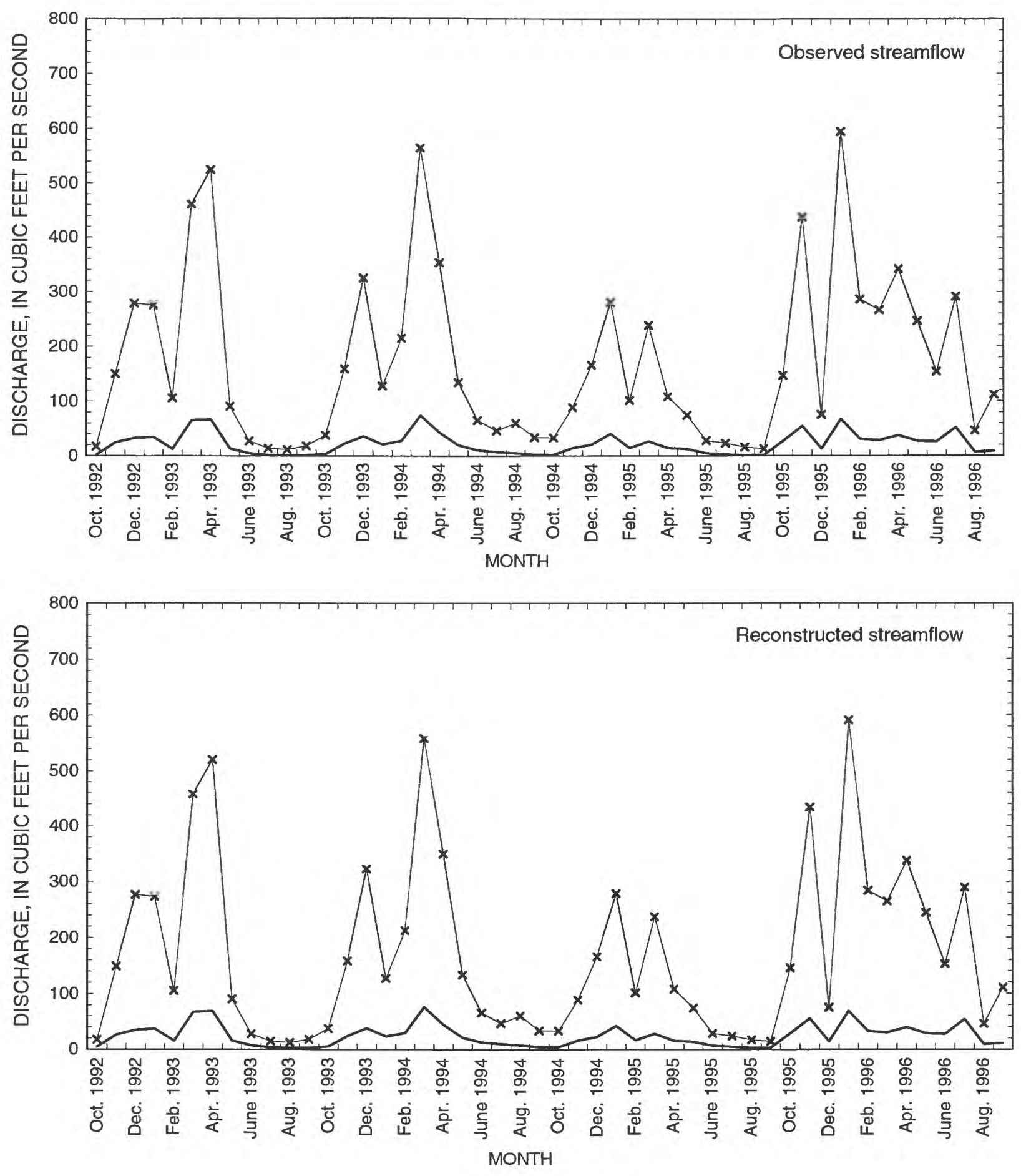

\section{EXPLANATION}

$\rightarrow 01387400$ Ramapo River at Ramapo, N.Y.

Figure 1-5a. Monthly mean observed and reconstructed streamflow for streamflow-gaging stations in the Ramapo River Basin, New Jersey and New York, October 1992-September 1996. 

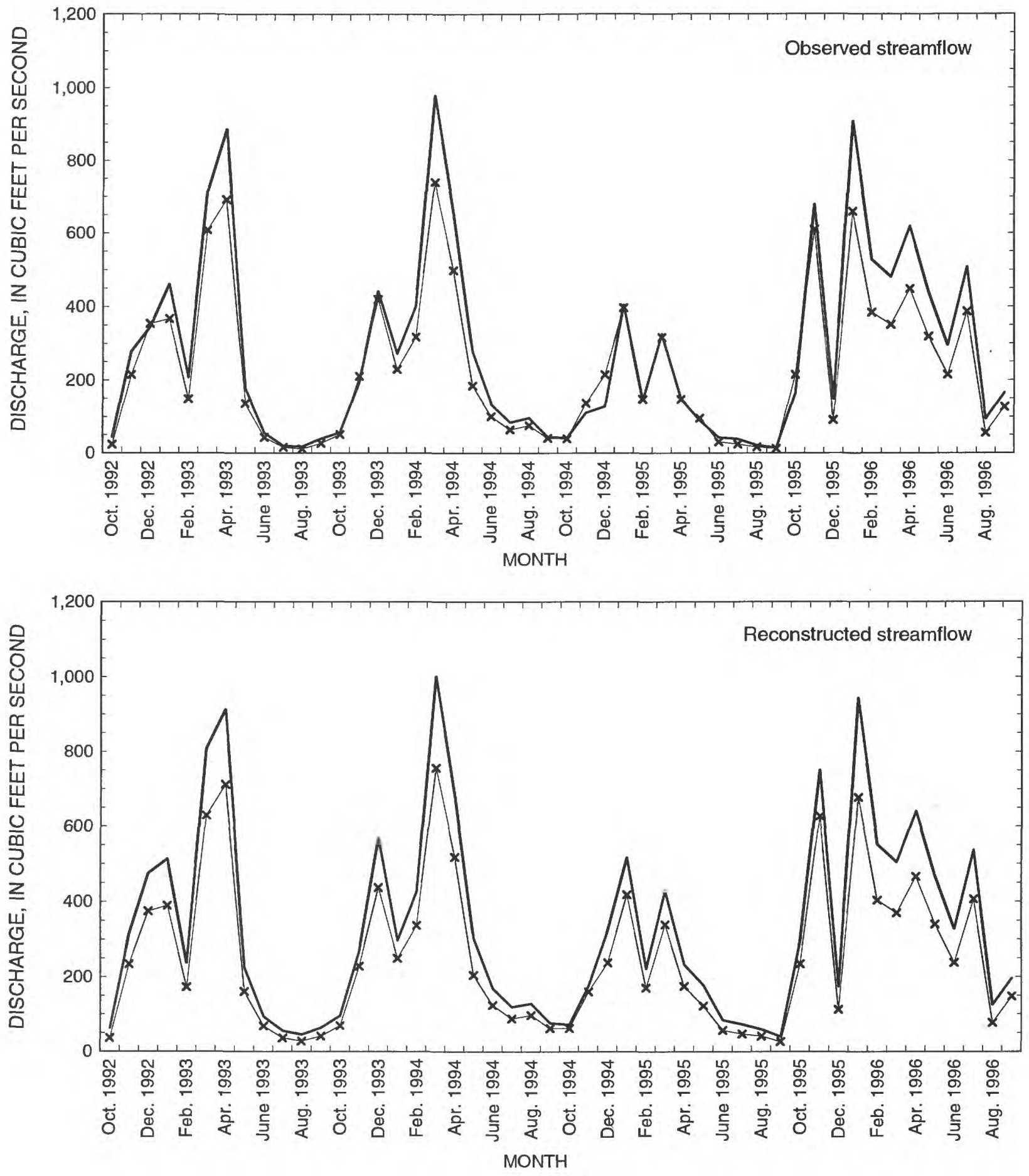

\section{EXPLANATION}

× 01387500 Ramapo River near Mahwah, N.J.

01388000 Ramapo River at Pompton Lakes, N.J.

Figure 1-5b. Monthly mean observed and reconstructed streamflow for streamflow-gaging stations in the Ramapo River Basin, New Jersey and New York, October 1992-September 1996--Continued. 

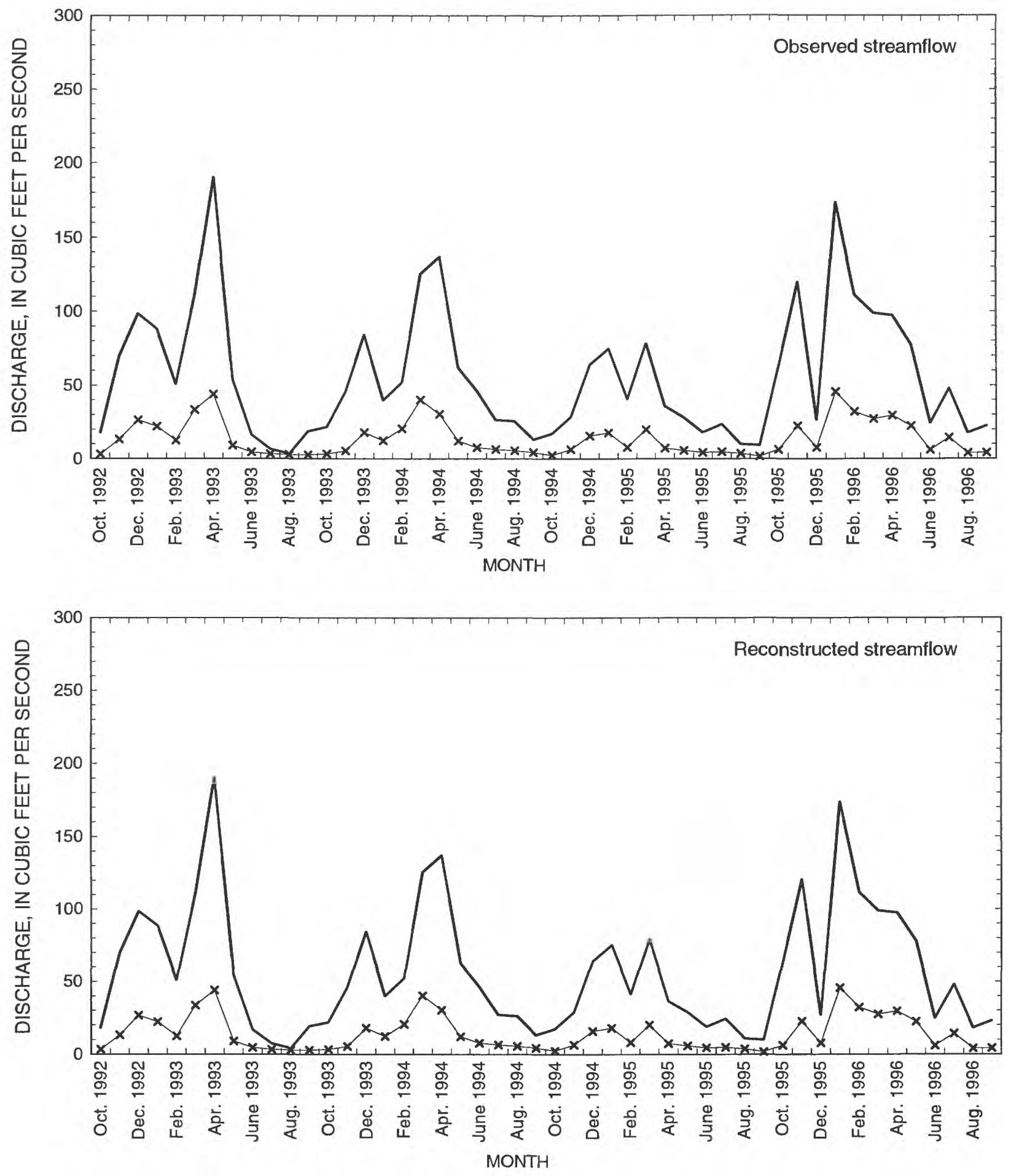

\section{EXPLANATION}

$\begin{array}{ll}-01379700 & \text { Rockaway River at Berkshire Valley, N.J. } \\ x-01379773 & \text { Green Pond Brook at Picatinny Arsenal, N.J. }\end{array}$

Figure 1-6a. Monthly mean observed and reconstructed streamflow for streamflow-gaging stations in the Rockaway River Basin, New Jersey, October 1992-September 1996. 

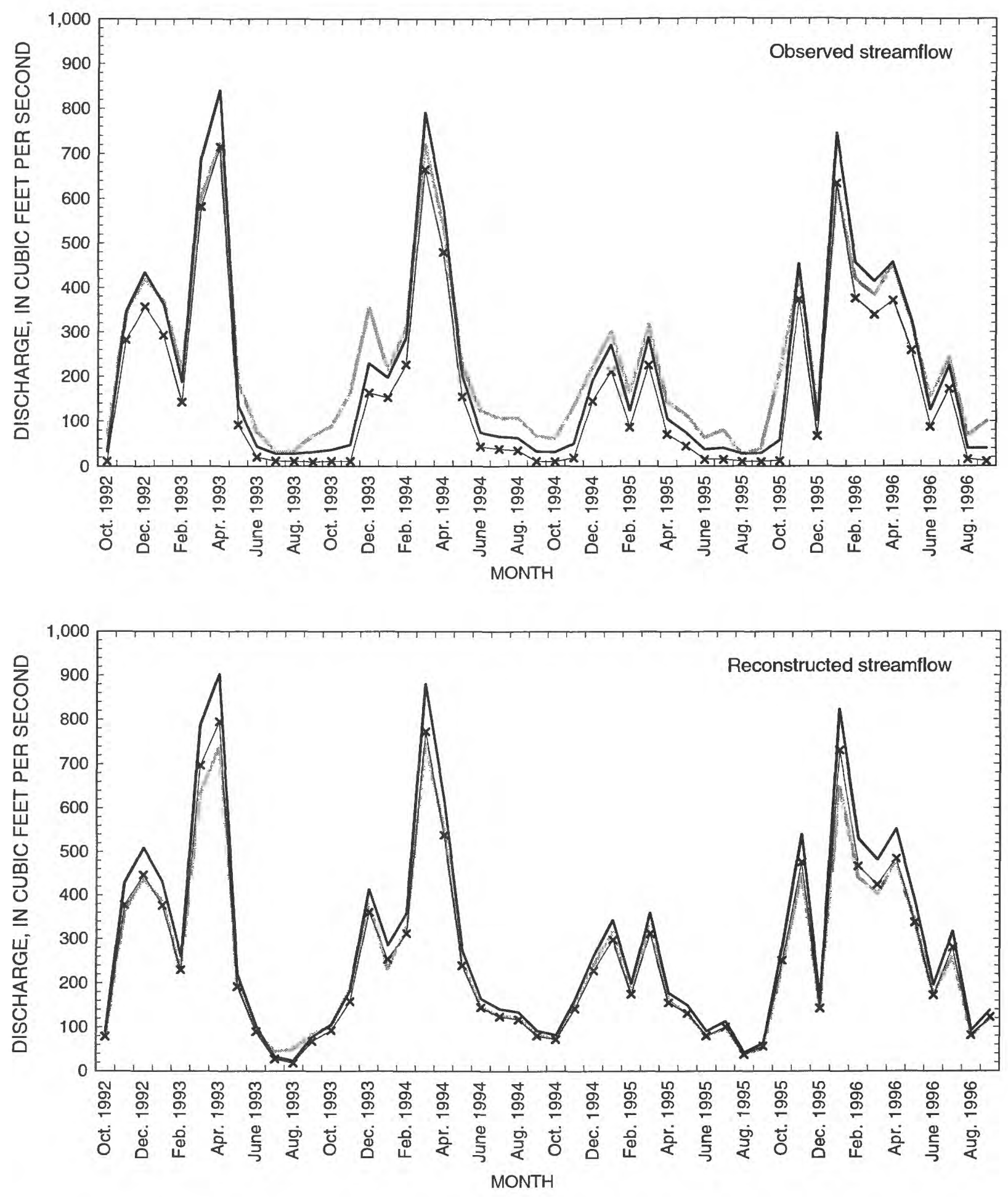

\section{EXPLANATION}

$\begin{aligned}-01380500 & \text { Rockaway River above reservoir at Boonton, N.J. } \\ \times 01381000 & \text { Rockaway River below reservoir at Boonton, N.J. } \\ -01381200 & \text { Rockaway River at Pine Brook, N.J. }\end{aligned}$

Figure 1-6b. Monthly mean observed and reconstructed streamflow for streamflow-gaging stations in the Rockaway River Basin, New Jersey, October 1992-September 1996--Continued. 

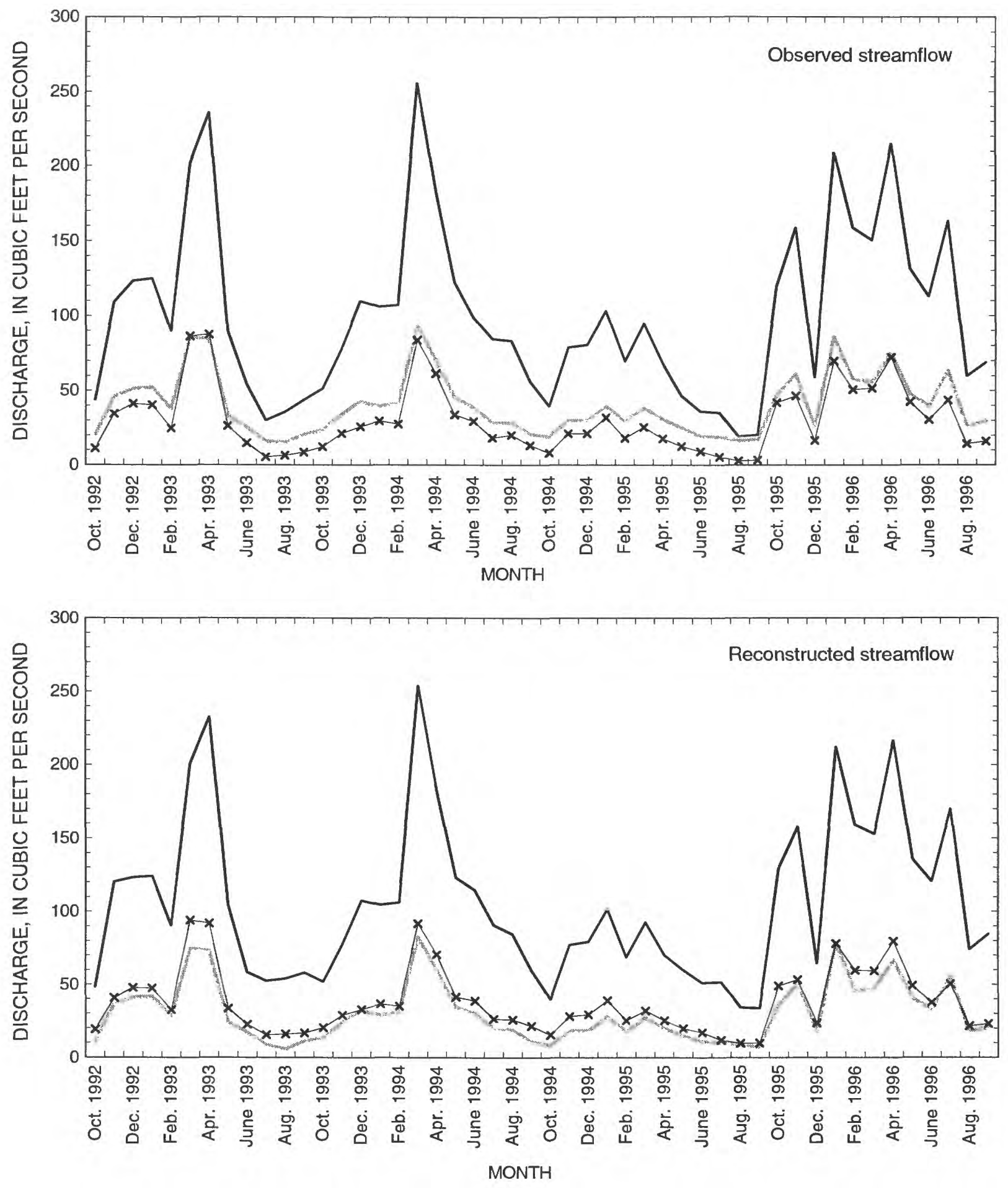

EXPLANATION

$\begin{aligned}-01391000 & \text { Saddle River at Ridgewood, N.J. } \\ \times 01390500 & \text { Hohokus Brook at Ho-Ho-Kus, N.J. } \\ -01391500 & \text { Saddle River at Lodi, N.J. }\end{aligned}$

Figure 1-7. Monthly mean observed and reconstructed streamflow for streamflow-gaging stations in the Saddle River Basin, New Jersey, October 1992-September 1996. 

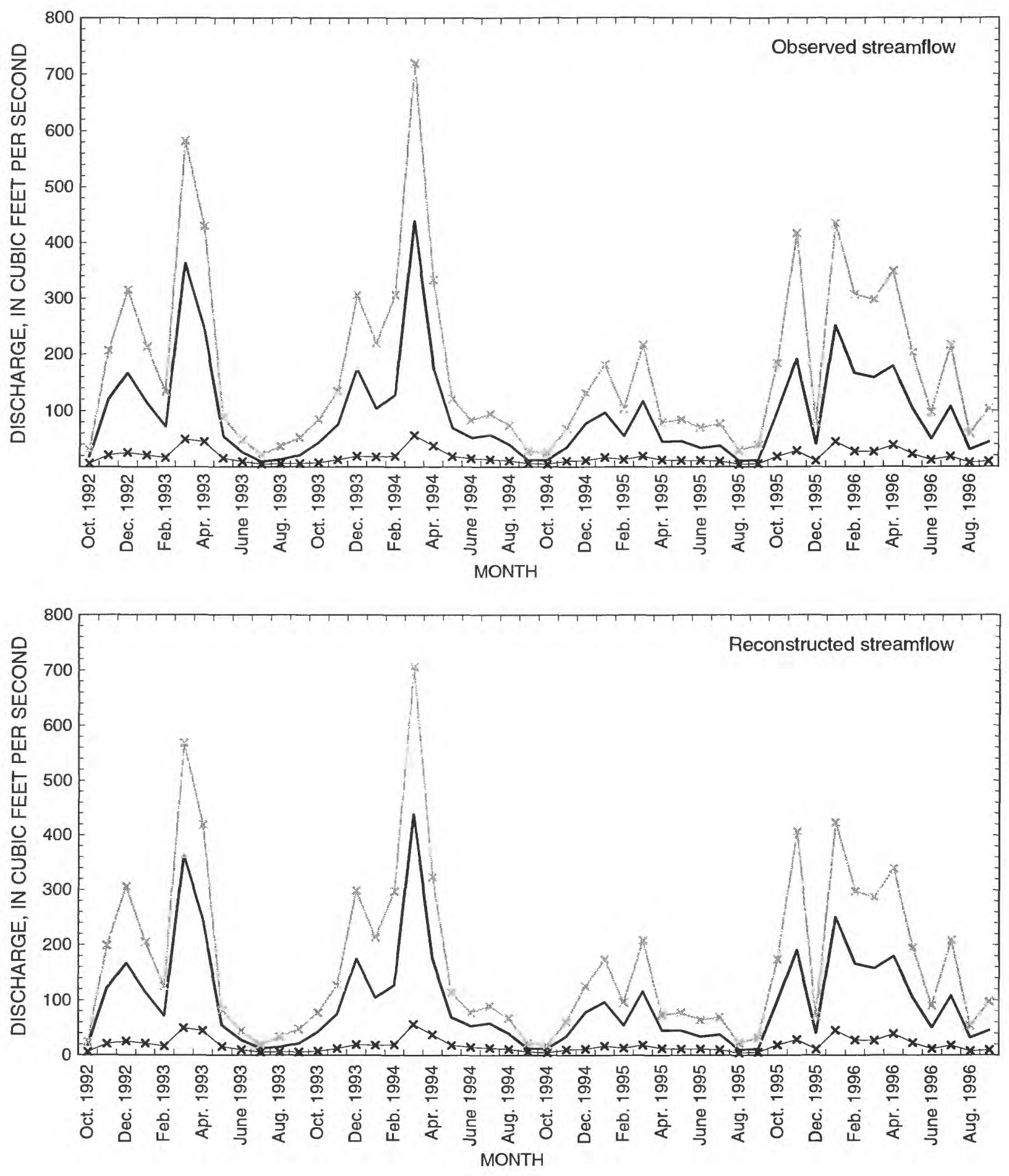

\section{EXPLANATION}

× 01378690 Passaic River near Bernardsville, N.J.

01379000 Passaic River near Millington, N.J.

- 01379500 Passaic River near Chatham, N.J.

Figure 1-8a. Monthly mean observed and reconstructed streamflow for streamflow-gaging stations in the Upper Passaic River Basin, New Jersey, October 1992-September 1996. 

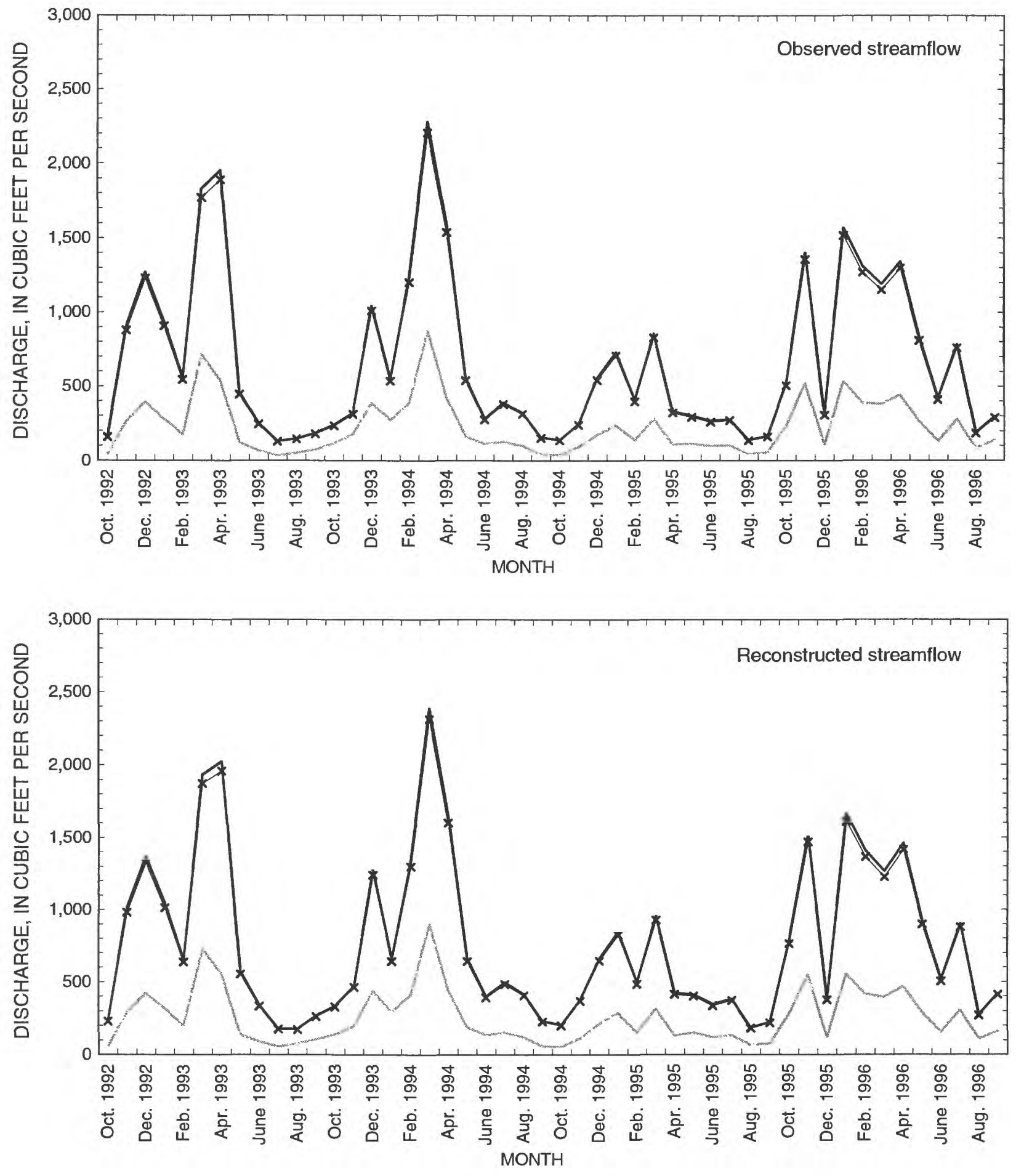

\section{EXPLANATION}

01379580 Passaic River near Hanover Neck, N.J.

$\times 01381900$ Passaic River at Pine Brook, N.J.

01382000 Passaic River at Two Bridges, N.J.

Figure 1-8b. Monthly mean observed and reconstructed streamflow for streamflow-gaging stations in the Upper Passaic River Basin, New Jersey, October 1992-September 1996--Continued. 

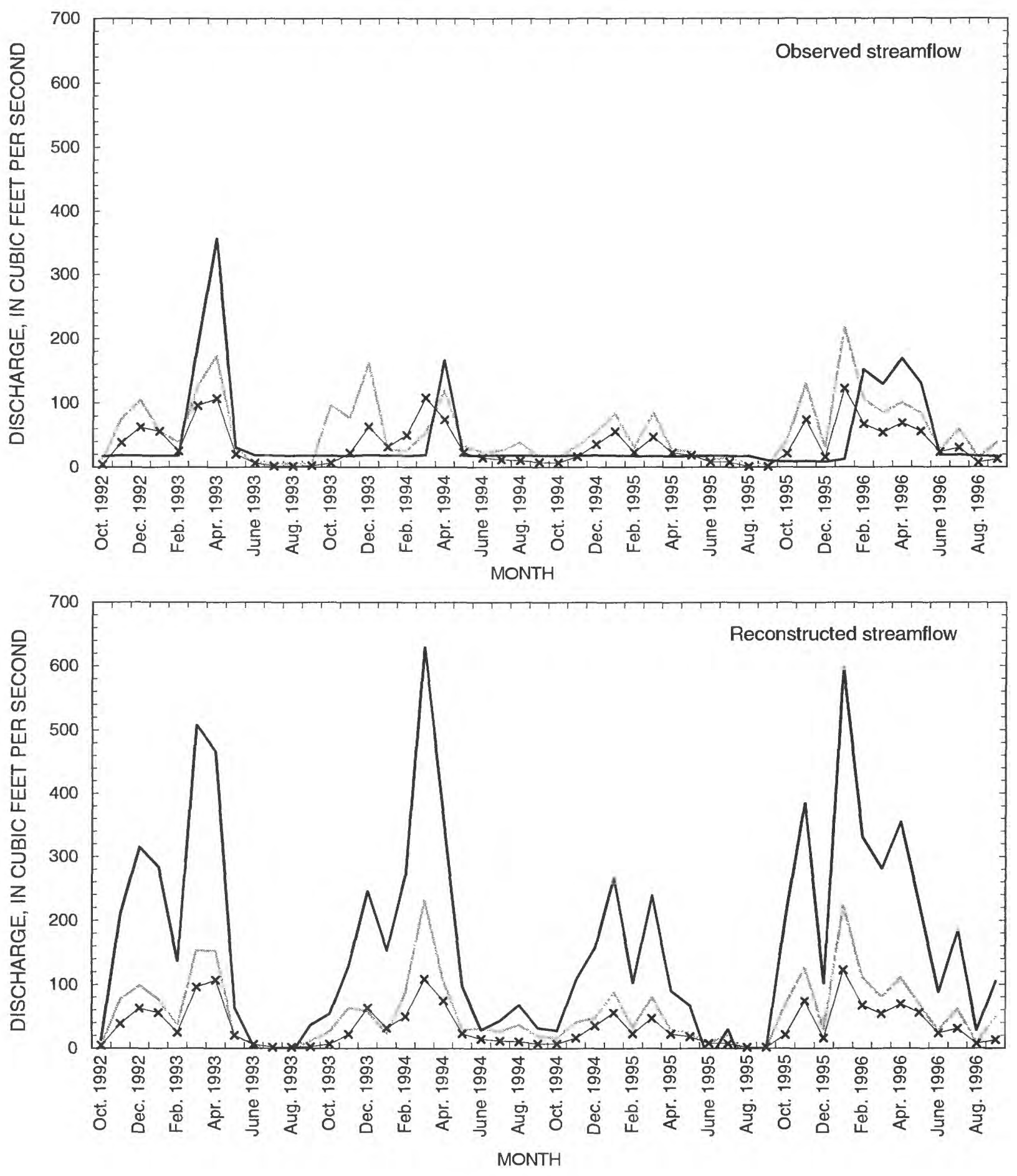

\section{EXPLANATION}

01383500 Wanaque River at Awosting, N.J.

$\rightarrow 01384500$ Ringwood Creek near Wanaque, N.J.

— 01387000 Wanaque River at Wanaque, N.J.

Figure 1-9. Monthly mean observed and reconstructed streamflow for streamflow-gaging stations in the Wanaque River Basin, New Jersey, October 1992-September 1996. 

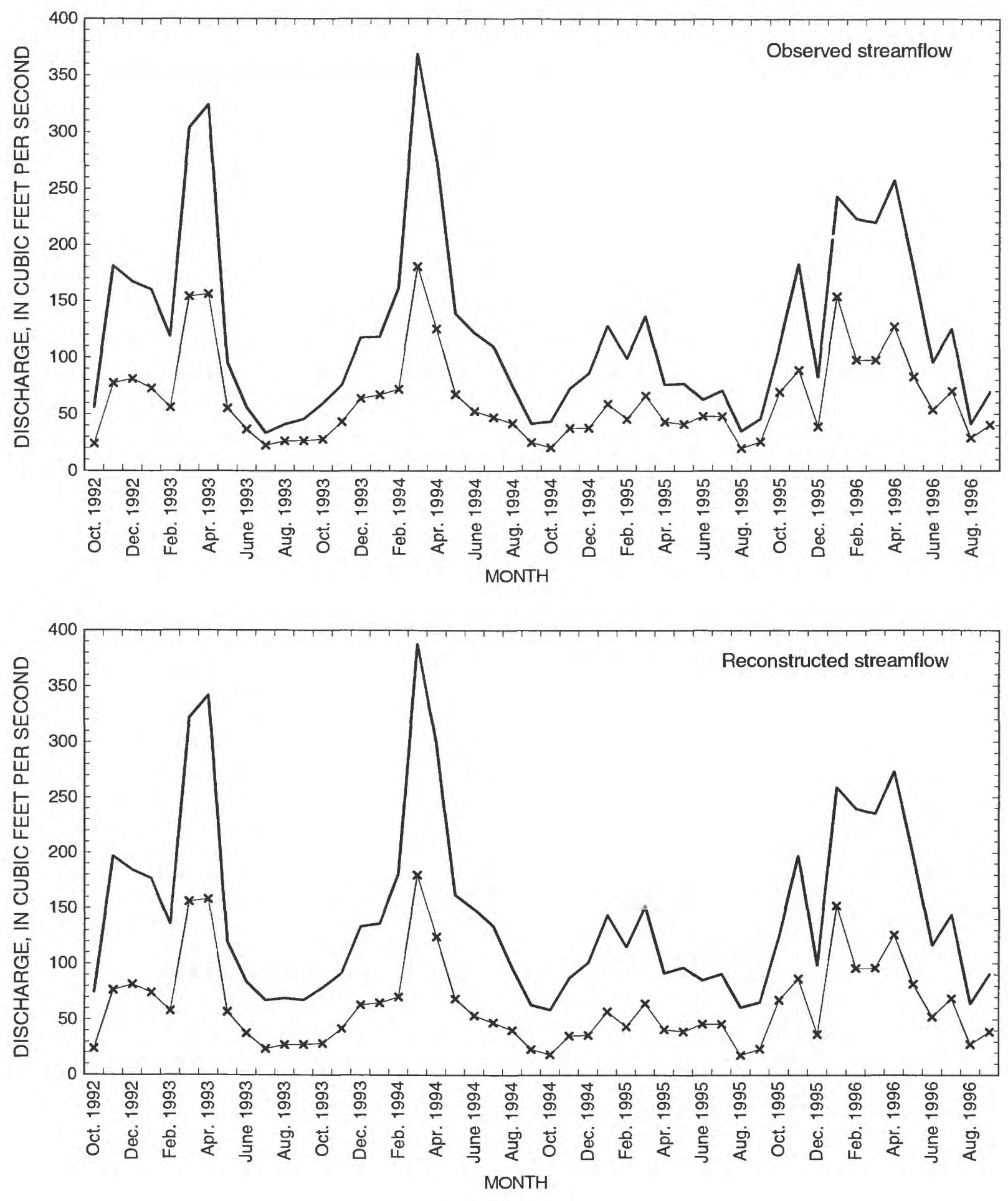

\section{EXPLANATION}

$\longrightarrow 01381500$ Whippany River at Morristown, N.J.

01381800 Whippany River near Pine Brook, N.J.

Figure 1-10. Monthly mean observed and reconstructed streamflow for streamflow-gaging stations in the Whippany River Basin, New Jersey, October 1992-September 1996. 
APPENDIX 2. DAILY MEAN OBSERVED AND RECONSTRUCTED STREAMFLOW FROM MAY 1, 1995, THROUGH OCTOBER 31, 1995, BY SUBWATERSHED FOR 34 STREAMFLOW-GAGING STATIONS IN THE PASSAIC AND HACKENSACK RIVER BASINS, NEW JERSEY AND NEW YORK 

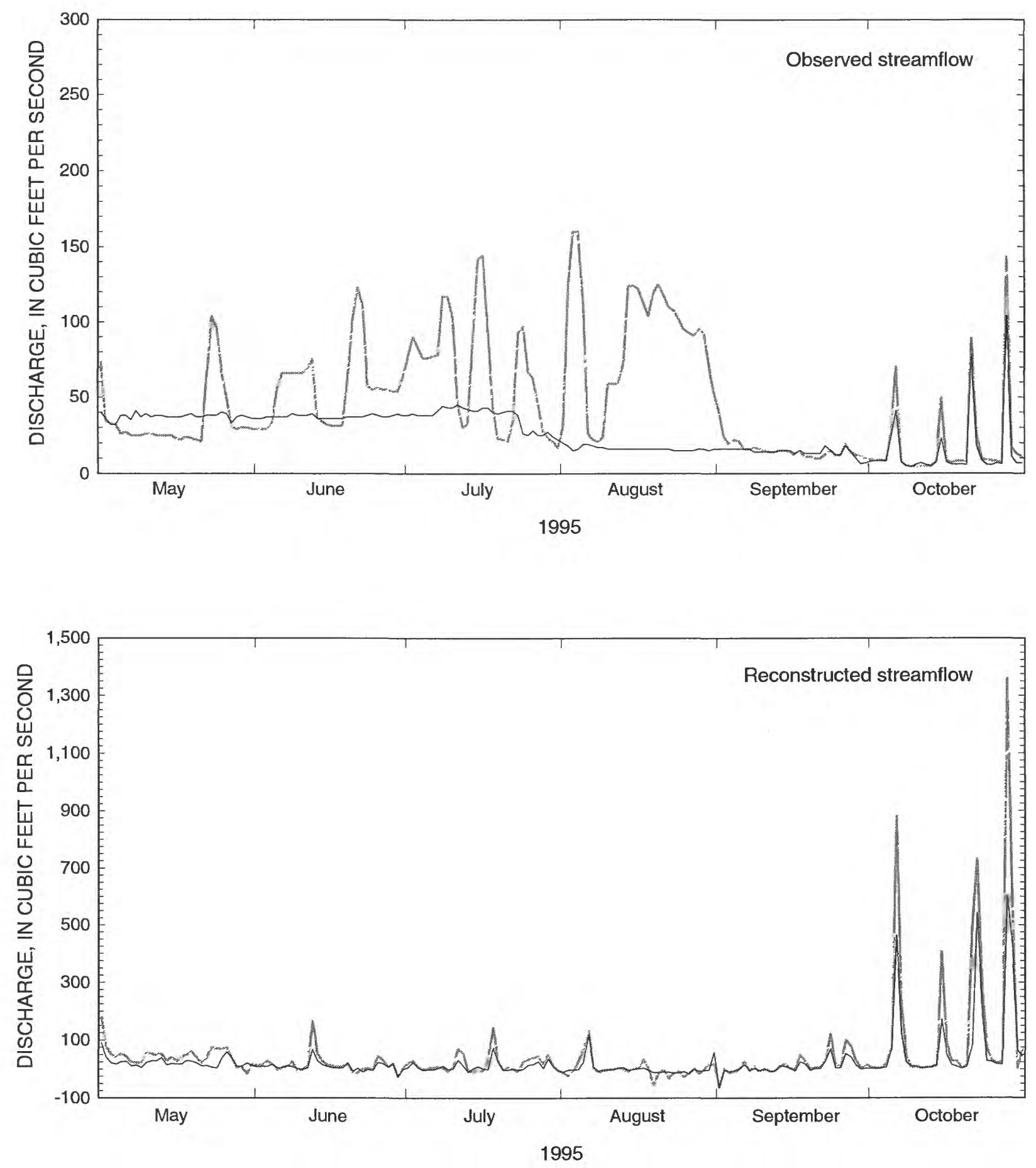

\section{EXPLANATION}

01376800 Hackensack River at West Nyack, N.Y.

01377000 Hackensack River at Rivervale, N.J.

Figure 2-1a. Daily mean observed and reconstructed streamflow for streamflow-gaging stations in the Hackensack River Basin, New Jersey and New York, May-October 1995. 

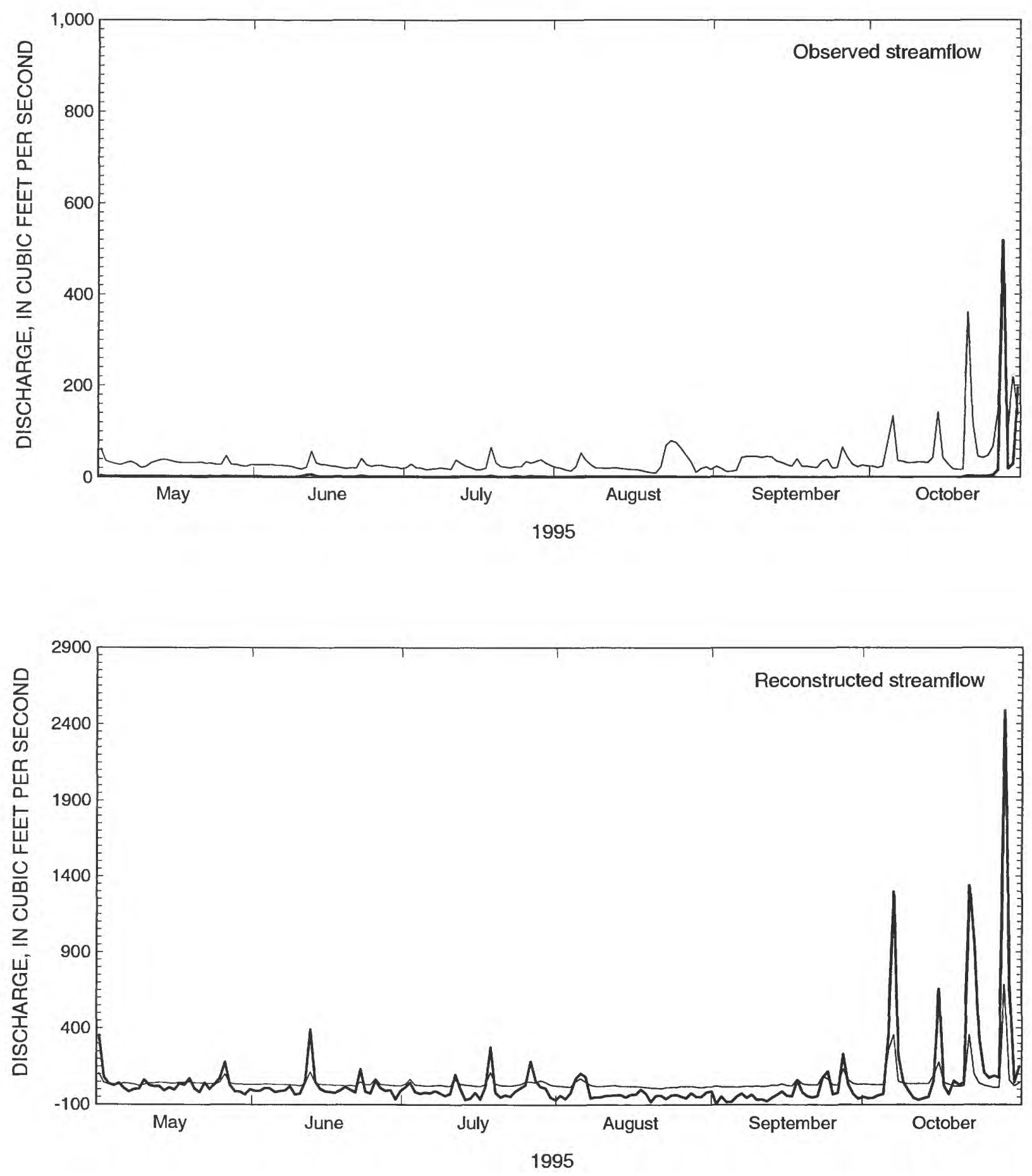

Figure 2-1b. Daily mean observed and reconstructed streamflow for streamflow-gaging stations in the Hackensack River Basin, New Jersey and New York, May-October 1995--Continued. 

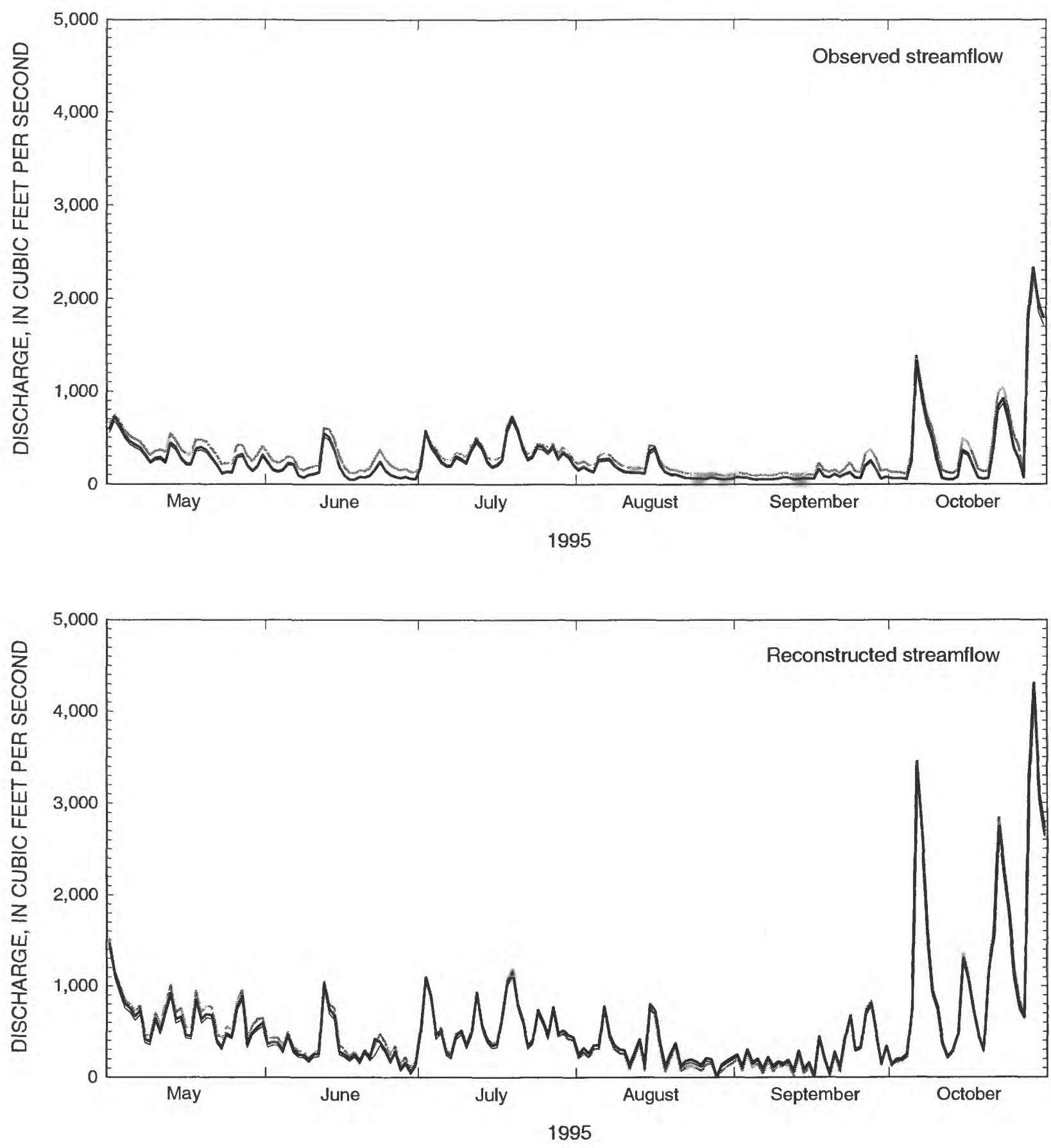

\section{EXPLANATION}

01389005 Passaic River below Pompton River at Two Bridges, N.J.

01389500 Passaic River at Little Falls, N.J.

01389880 Passaic River at Rt. 46 at Elmwood Park, N.J.

Figure 2-2. Daily mean observed and reconstructed streamflow for streamflow-gaging stations in the Lower Passaic River Basin, New Jersey, May-October 1995. 

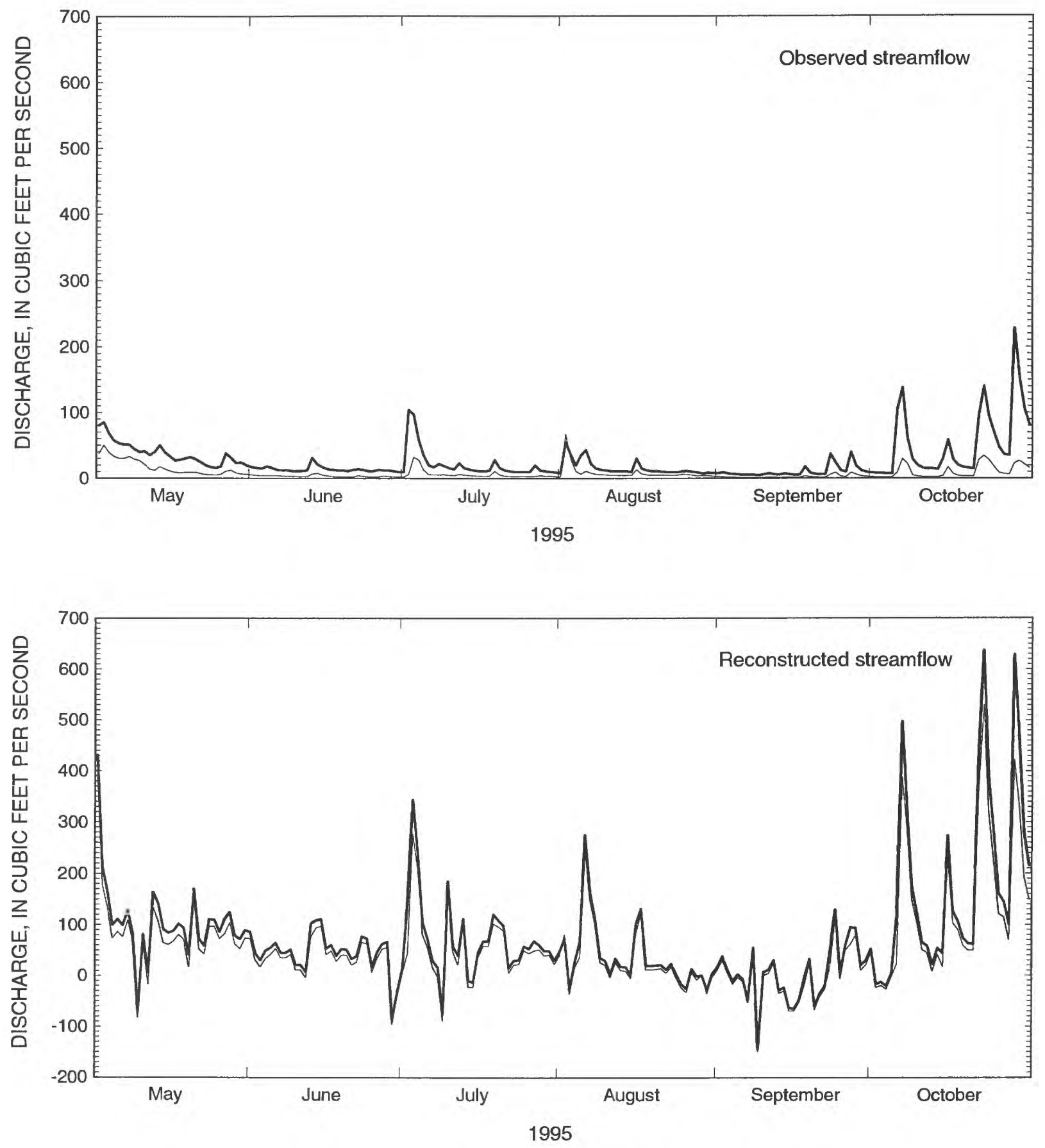

\section{EXPLANATION}

01382500 Pequannock River at Macopin Intake Dam, N.J.

01382800 Pequannock River at Riverdale, N.J.

Figure 2-3. Daily mean observed and reconstructed streamflow for streamflow-gaging stations in the Pequannock River Basin, New Jersey, May-October 1995. 

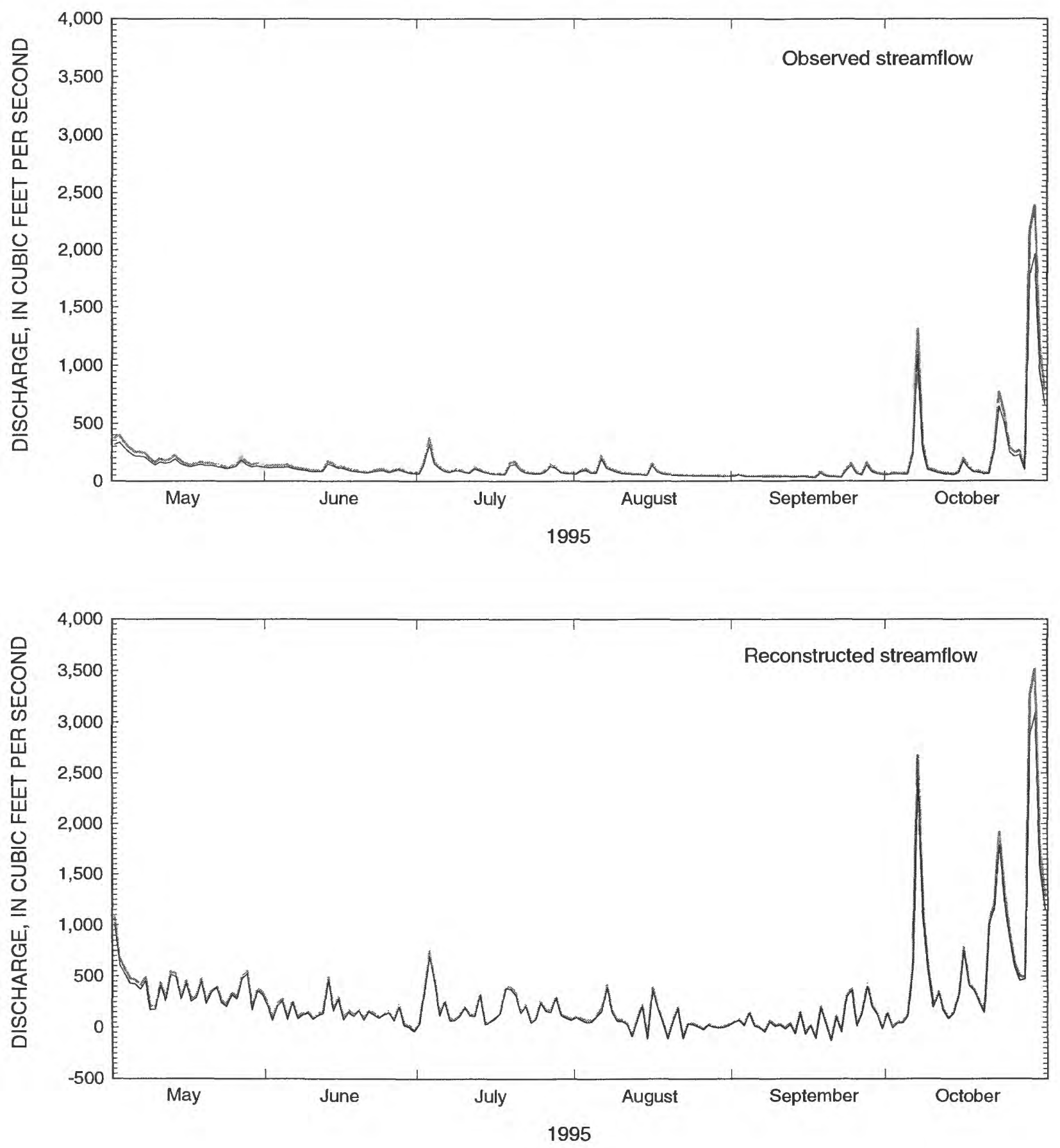

\section{EXPLANATION}

01388500 Pompton River at Pompton Plains, N.J.

01388910 Pompton River at Mountain View, N.J.

Figure 2-4. Daily mean observed and reconstructed streamflow for streamflow-gaging stations in the Pompton River Basin, New Jersey, May-October 1995. 

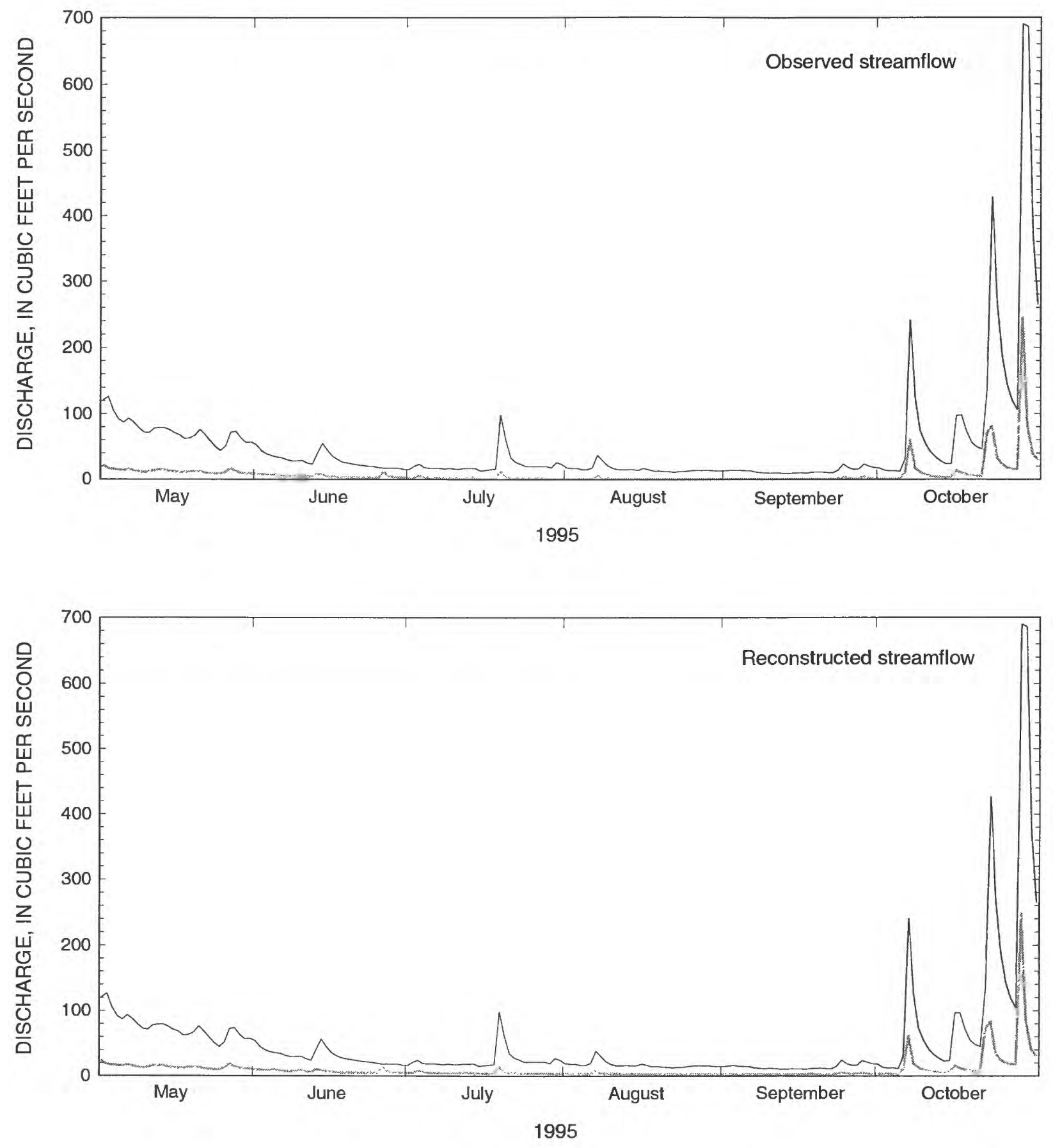

\section{EXPLANATION}

01387400 Ramapo River at Ramapo, N.Y.

01387450 Mahwah River near Suffern, N.Y.

Figure 2-5a. Daily mean observed and reconstructed streamflow for streamflow-gaging stations in the Ramapo River Basin, New Jersey and New York, May-October 1995. 

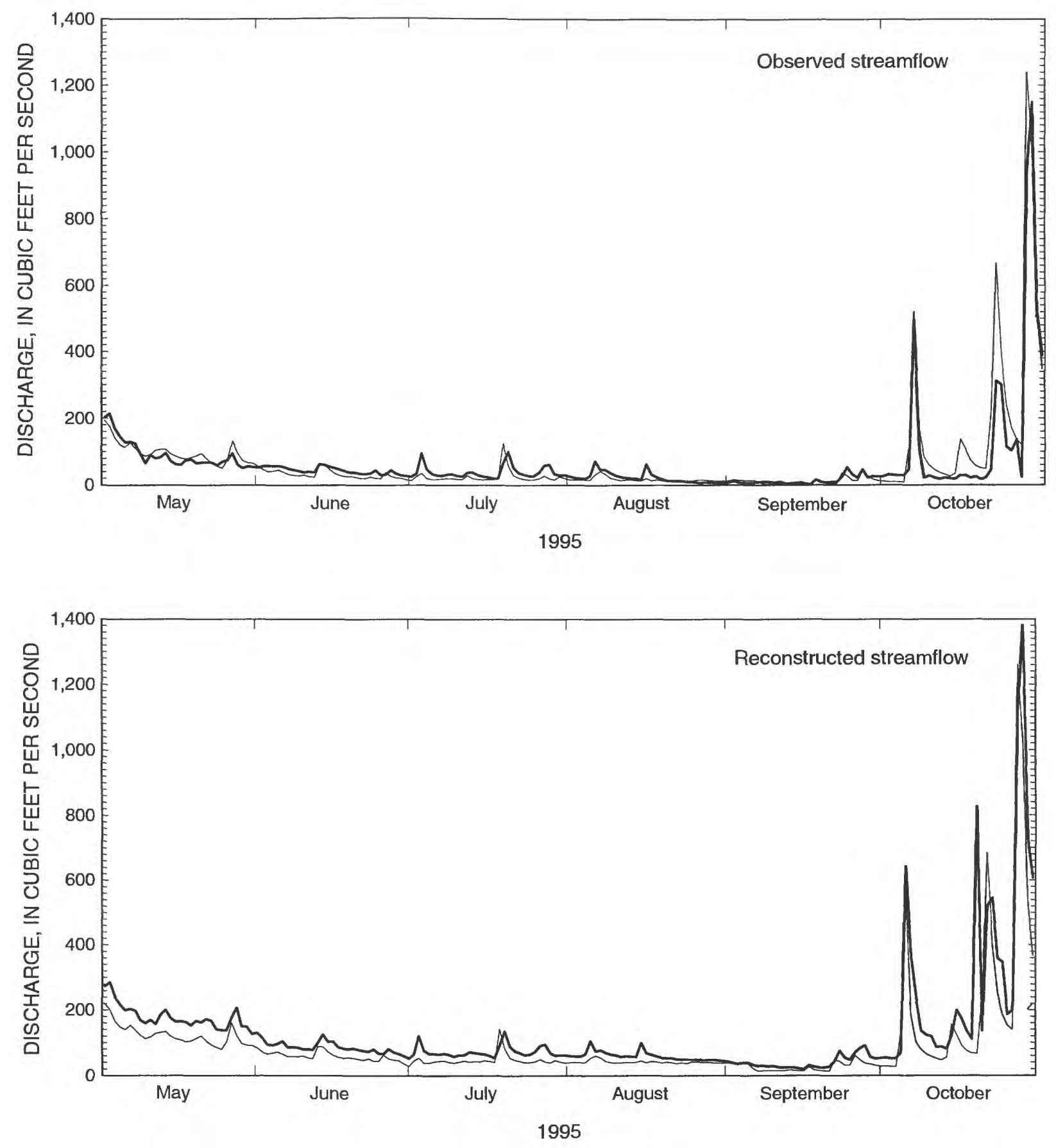

\section{EXPLANATION}

01387500 Ramapo River near Mahwah, N.J.

01388000 Ramapo River at Pompton Lakes, N.J.

Figure 2-5b. Daily mean observed and reconstructed streamflow for streamflow-gaging stations in the Ramapo River Basin, New Jersey and New York, May-October 1995--Continued. 

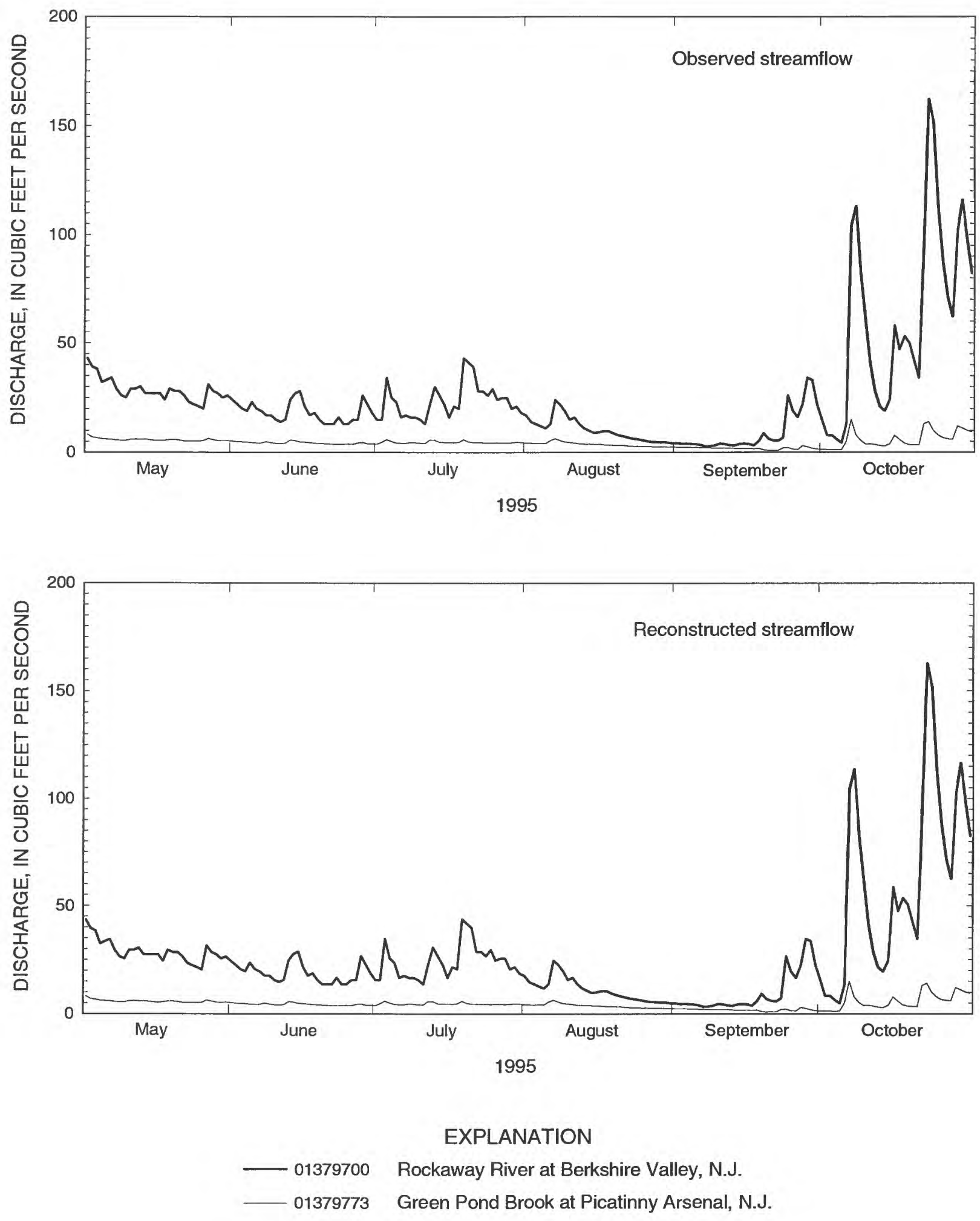

Figure 2-6a. Daily mean observed and reconstructed streamflow for streamflow-gaging stations in the Rockaway River Basin, New Jersey, May-October 1995. 

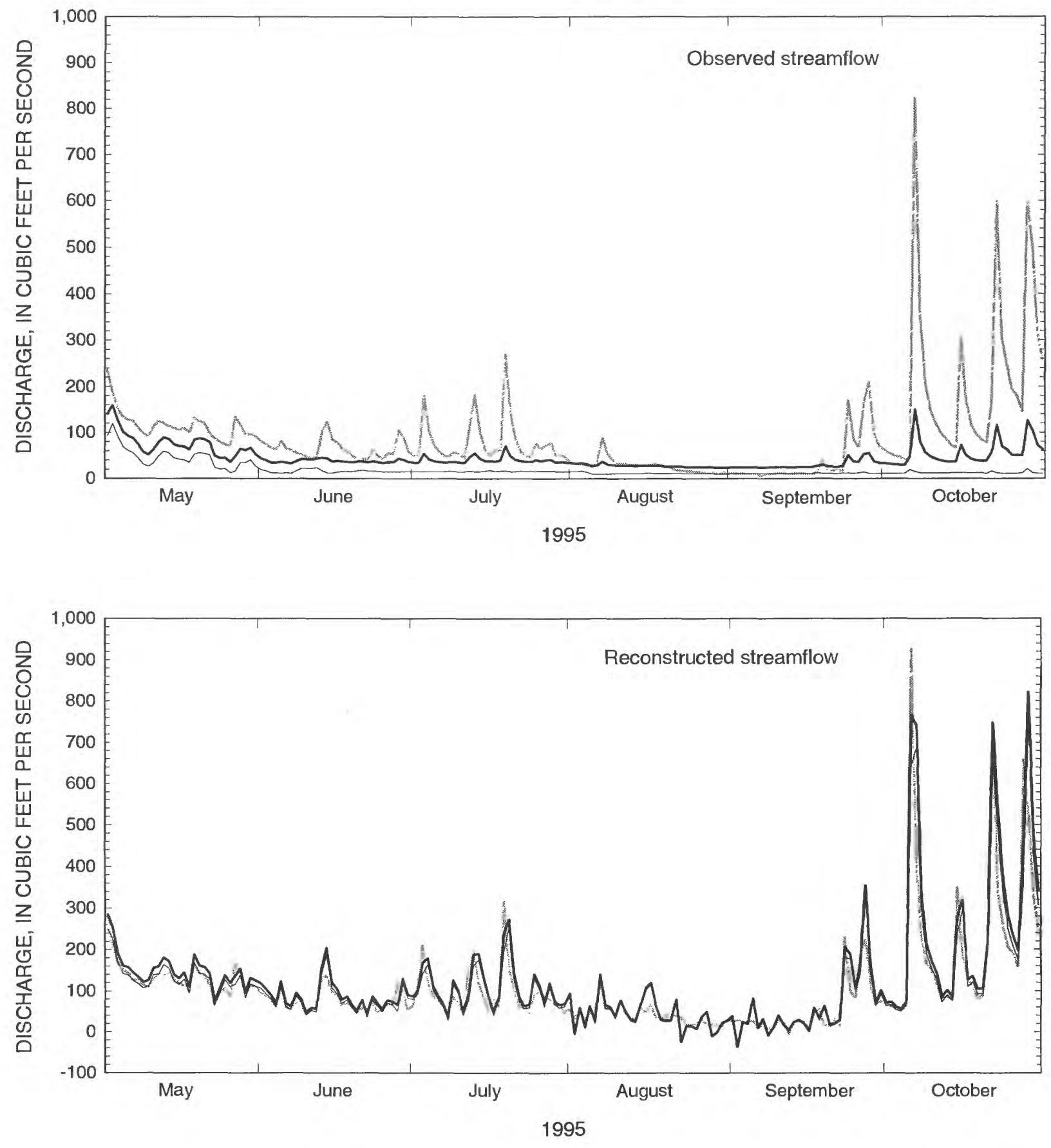

\section{EXPLANATION}

01380500 Rockaway River above reservoir at Boonton, N.J.

01381000 Rockaway River below reservoir at Boonton, N.J.

01381200 Rockaway River at Pine Brook, N.J.

Figure 2-6b. Daily mean observed and reconstructed streamflow for streamflow-gaging stations in the Rockaway River Basin, New Jersey, May-October 1995--Continued. 

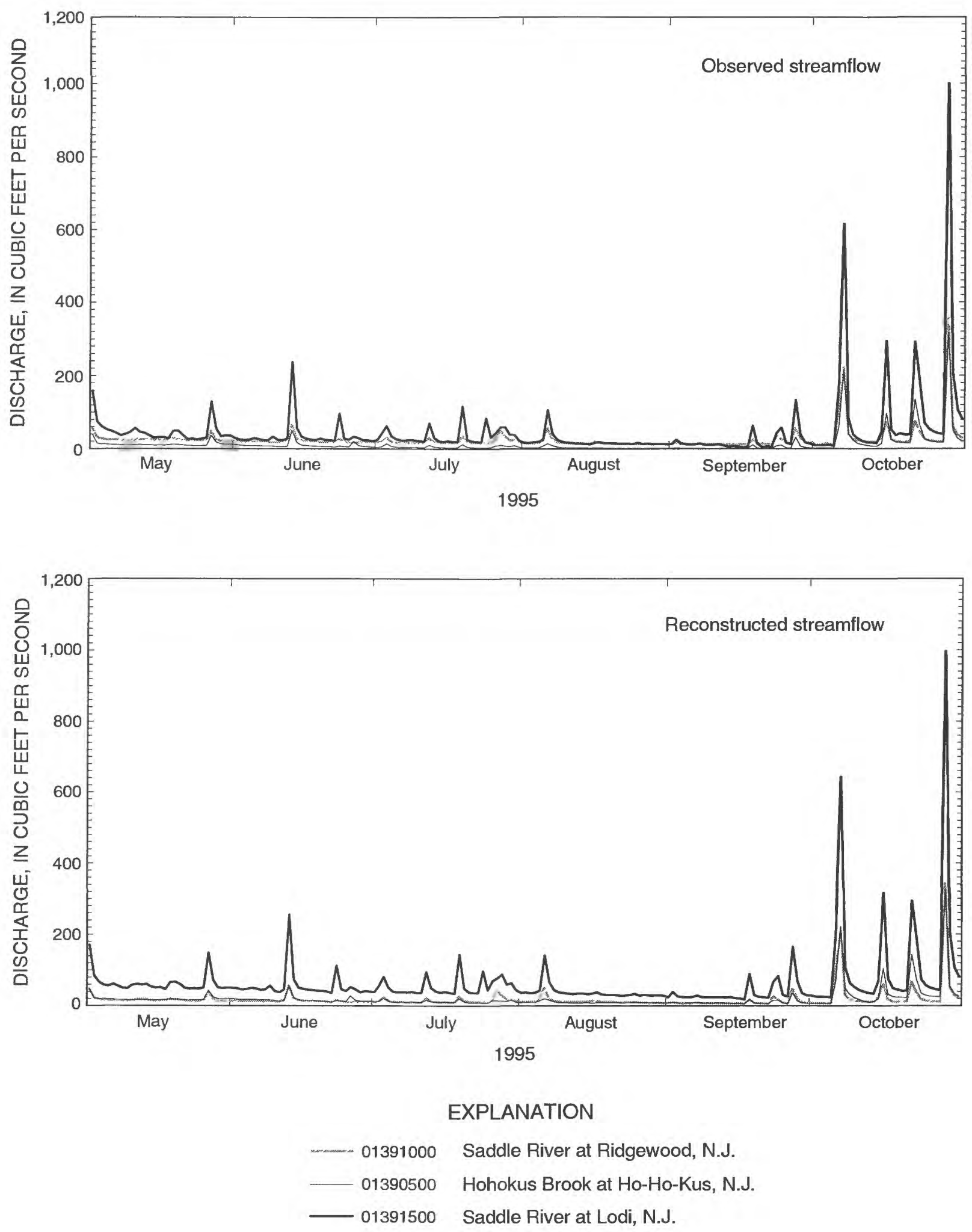

Figure 2-7. Daily mean observed and reconstructed streamflow for streamflow-gaging stations in the Saddle River Basin, New Jersey, May-October 1995. 

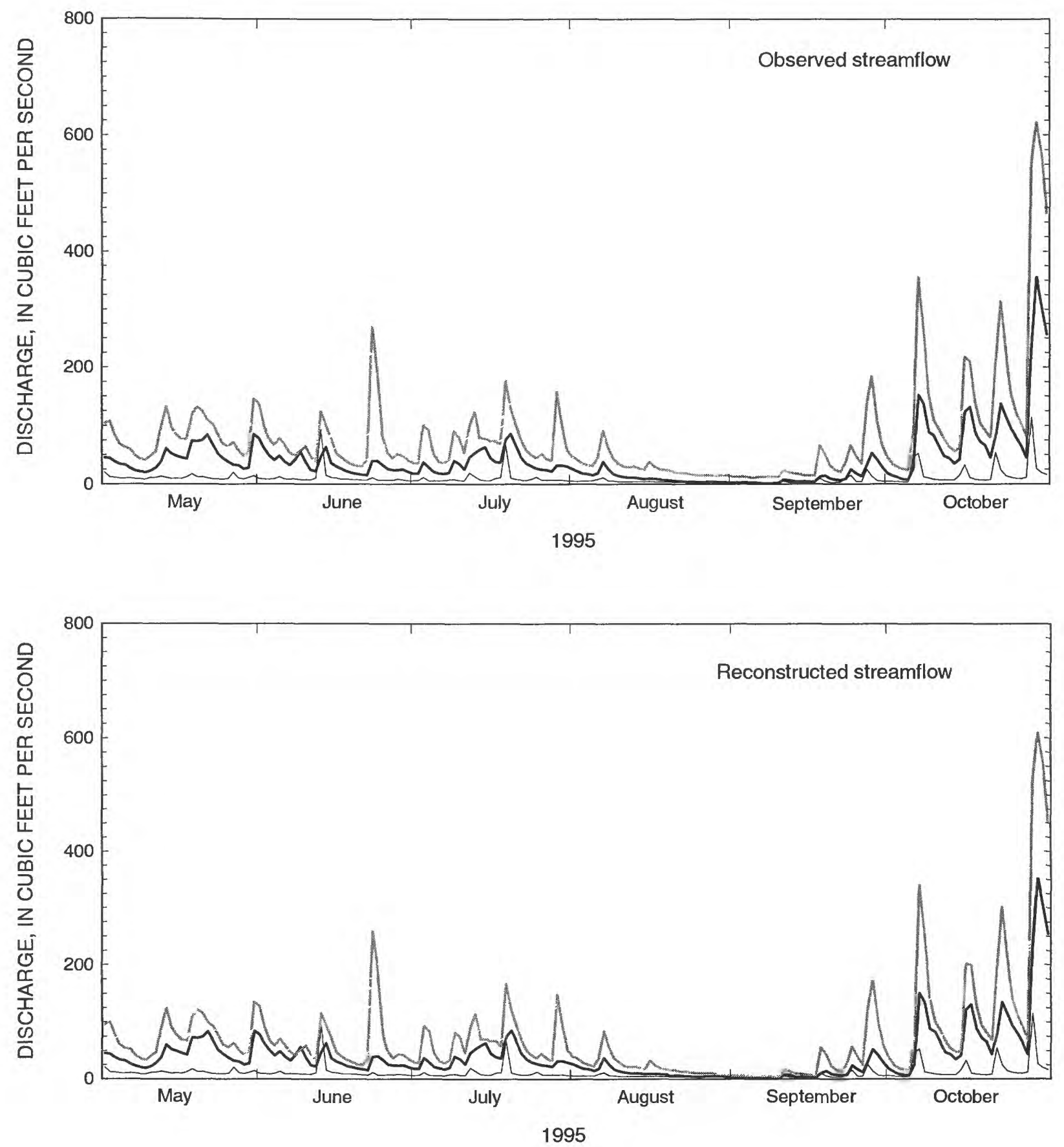

\section{EXPLANATION}

01378690 Passaic River near Bernardsville, N.J.

01379000 Passaic River near Millington, N.J.

01379500 Passaic River near Chatham, N.J.

Figure 2-8a. Daily mean observed and reconstructed streamflow for streamflow-gaging stations in the Upper Passaic River Basin, New Jersey, May-October 1995. 

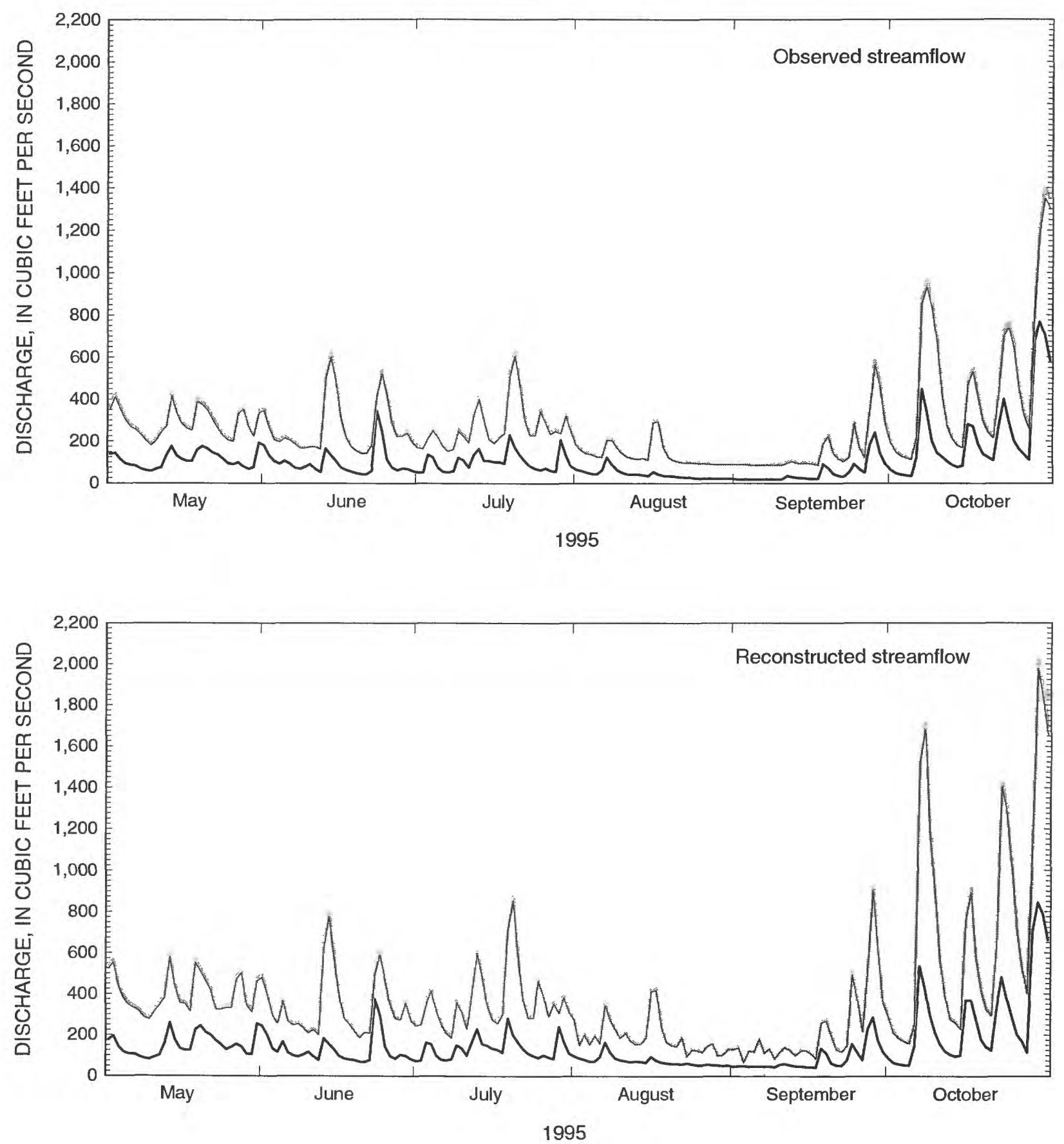

EXPLANATION

$\begin{aligned}-01379580 & \text { Passaic River near Hanover Neck, N.J. } \\ 01381900 & \text { Passaic River at Pine Brook, N.J. } \\ 01382000 & \text { Passaic River at Two Bridges, N.J. }\end{aligned}$

Figure 2-8b. Daily mean observed and reconstructed streamflow for streamflow-gaging stations in the Upper Passaic River Basin, New Jersey, May-October 1995--Continued. 

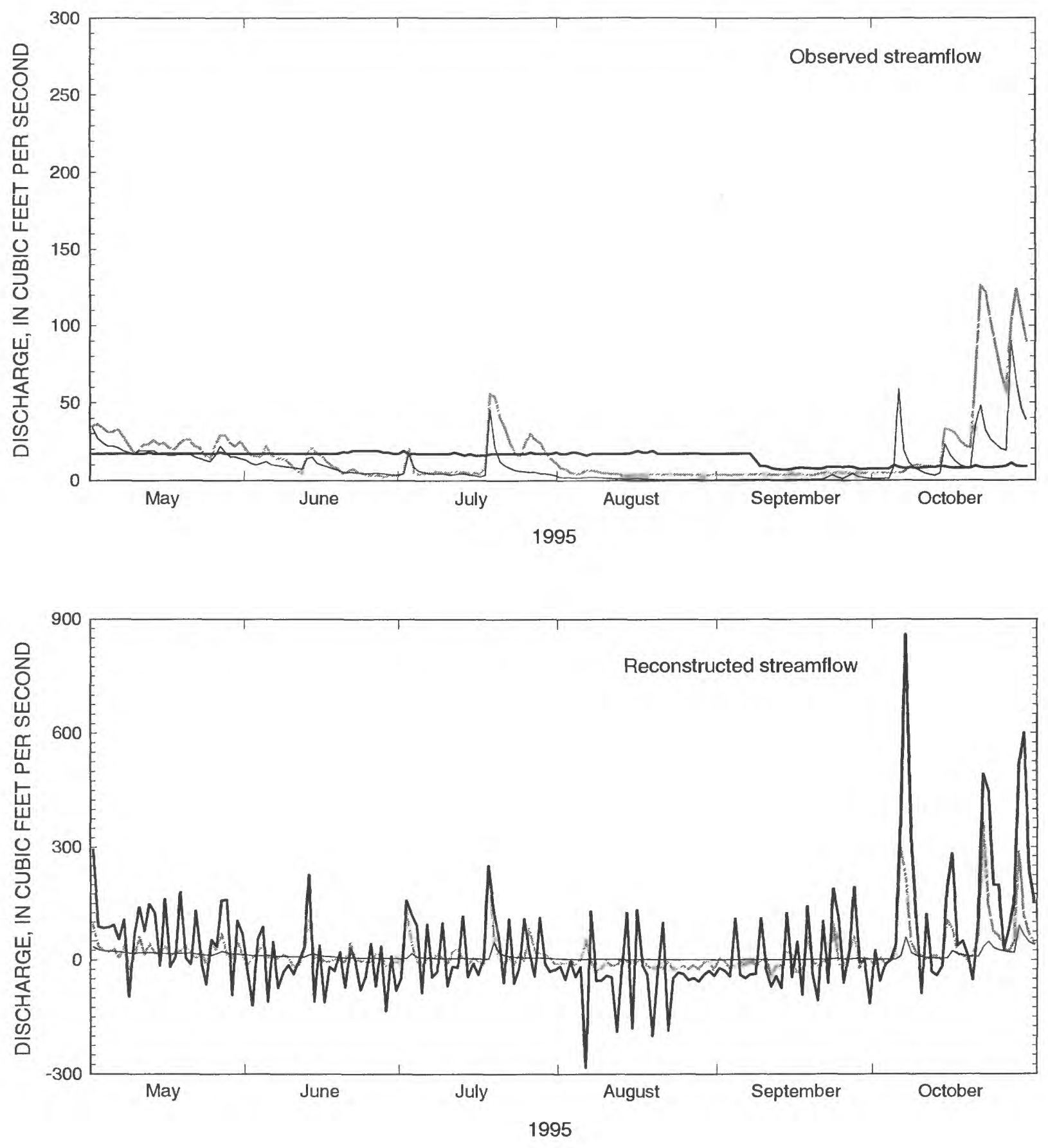

\section{EXPLANATION}

01383500 Wanaque River at Awosting, N.J.

01384500 Ringwood Creek near Wanaque, N.J.

01387000 Wanaque River at Wanaque, N.J.

Figure 2-9. Daily mean observed and reconstructed streamflow for streamflow-gaging stations in the Wanaque River Basin, New Jersey, May-October 1995. 

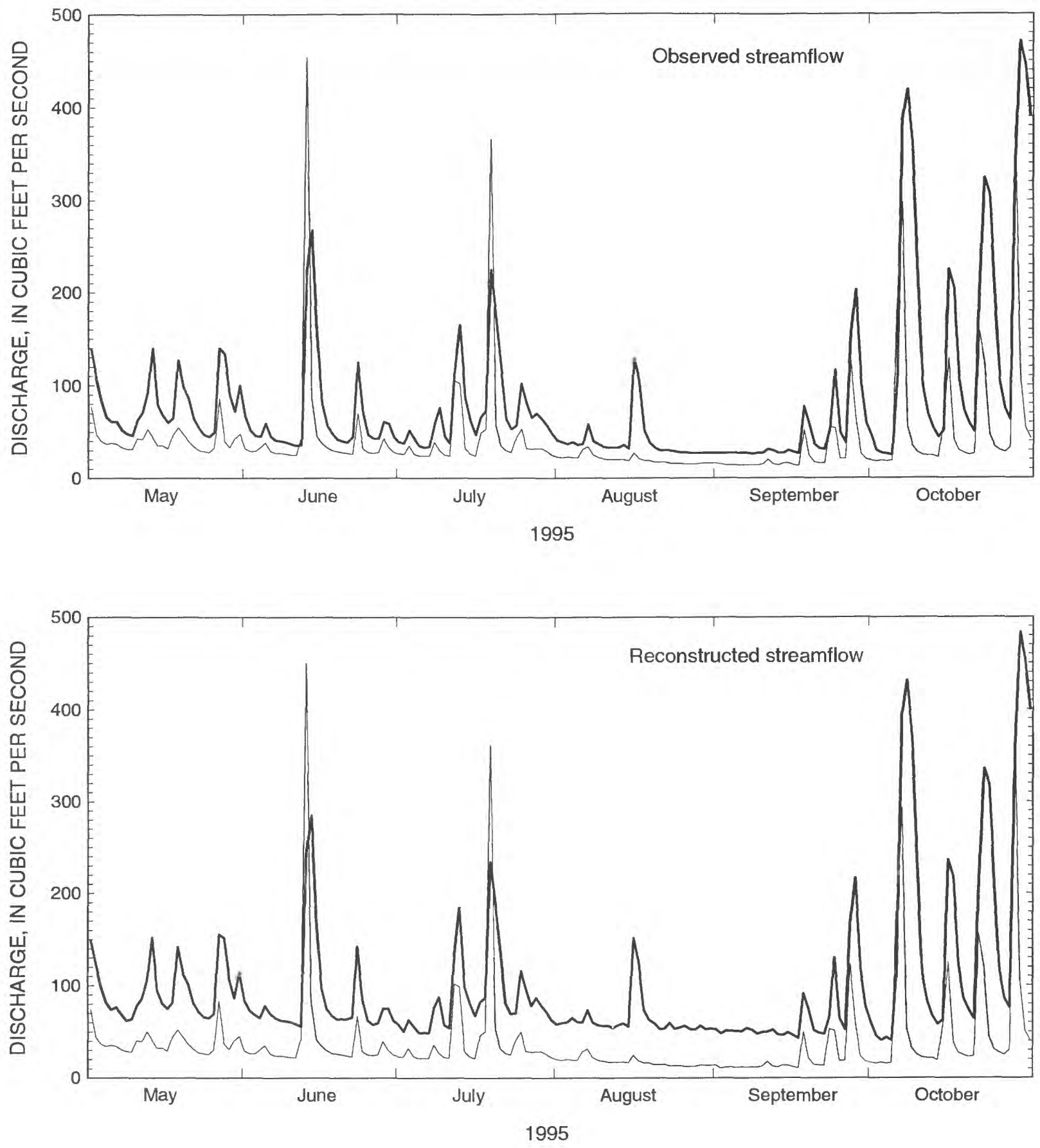

Figure 2-10. Daily mean observed and reconstructed streamflow for streamflow-gaging stations in the Whippany River Basin, New Jersey, May-October 1995. 
